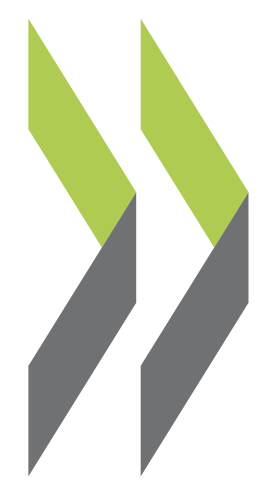

OECD Economics Department Working Papers No. 676

Taking Stock of Existing Structural Policy and Outcome Indicators

Davide Furceri, Annabelle Mourougane 


\section{Unclassified}

Organisation de Coopération et de Développement Économiques

Organisation for Economic Co-operation and Development

ECONOMICS DEPARTMENT

English - Or. English

TAKING STOCK OF EXISTING STRUCTURAL POLICY AND OUTCOME INDICATORS

ECONOMICS DEPARTMENT WORKING PAPER No. 676

by Davide Furceri and Annabelle Mourougane

All Economics Department Working Papers are available through OECD's internet web site at www.oecd.org/Working_Papers 


\section{TABLE OF CONTENTS}

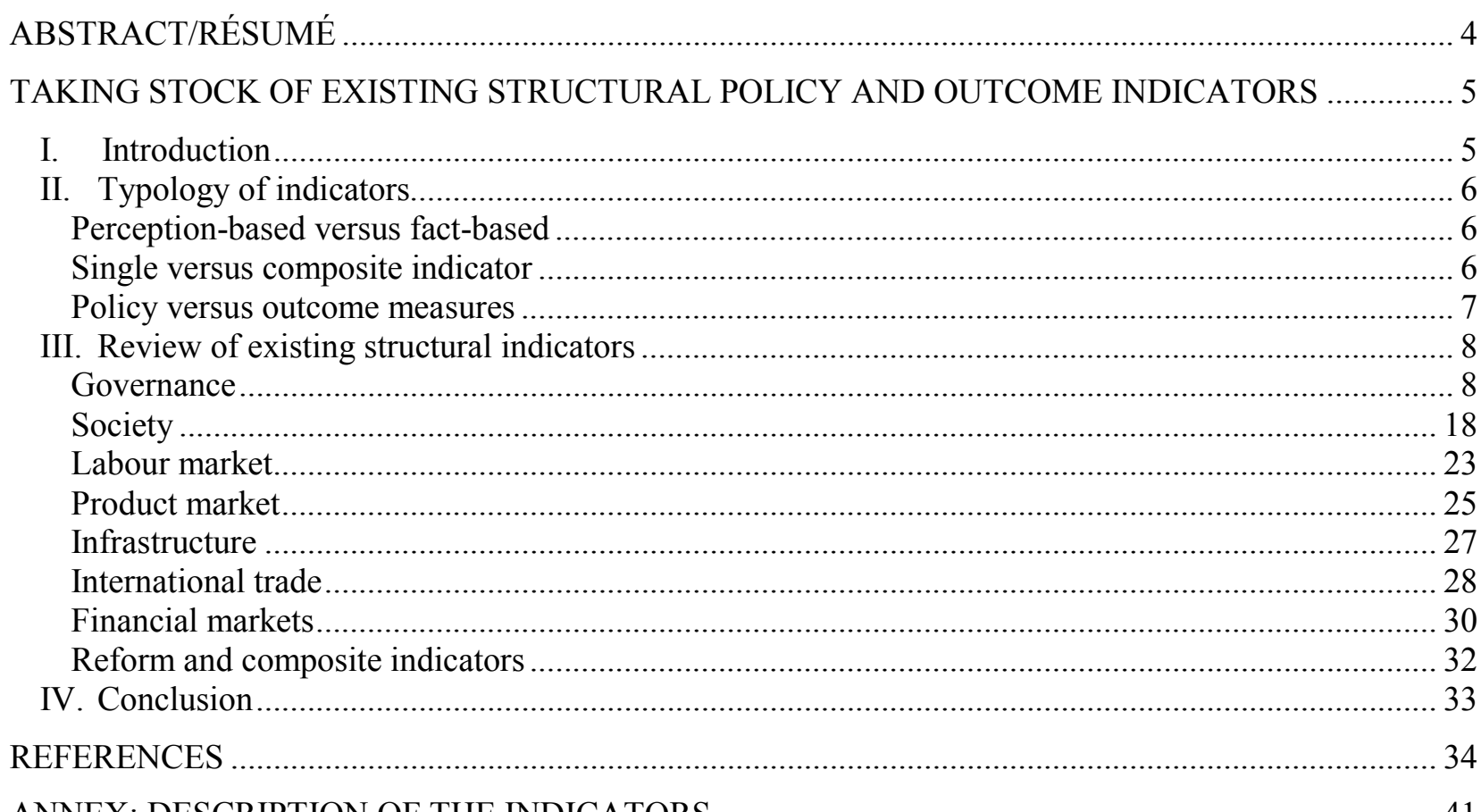

ANNEX: DESCRIPTION OF THE INDICATORS

\section{Tables}

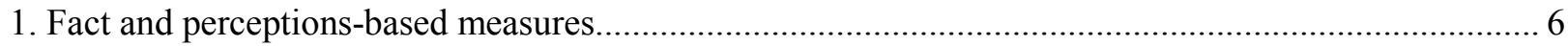

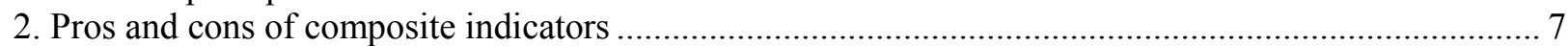

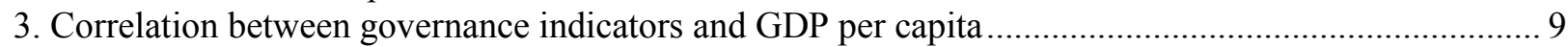

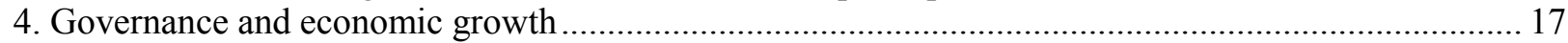

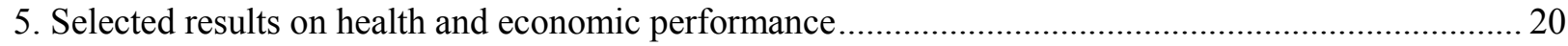

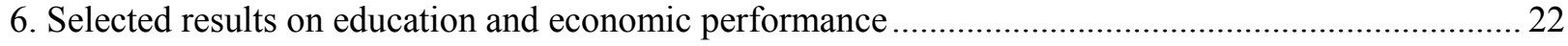

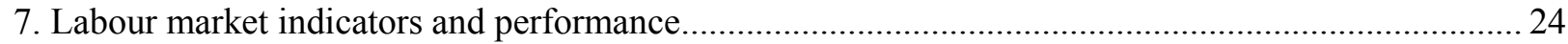

8. Product market indicators and economic performance ..................................................................... 27

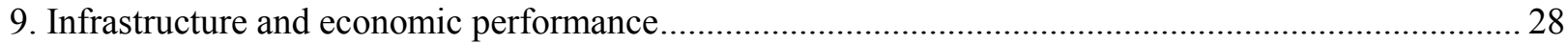

10. Growth and economic performance: effects of real export growth on real GDP growth................... 30

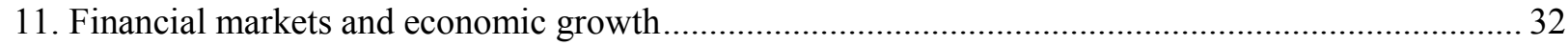

\section{Figures}

1. Correlation between selected Governance Matters indicators and GDP per capita 
2. Correlation between Doing Business property right and GDP per capita ......................................... 14

3. Correlation between Polity IV political indicator and GDP per capita ............................................ 15

4. Correlation between selected indicators of corruption and GDP per capita........................................ 16

5. Correlation between life expectancy and GDP per capita ............................................................ 21

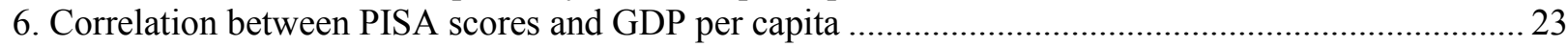

7. Correlation between selected indicators of financial developments and GDP per capita .................... 31 


\section{ABSTRACT/RÉSUMÉ}

\section{Taking stock of existing structural policy and outcome indicators}

This paper reviews and assesses in terms of availability, reliability and transparency existing policy and outcome indicators that have been found to be linked both directly and indirectly to economic growth and living standards. Indicators aiming at capturing the political and social situation of countries, as well as governance-related issues, are examined (e.g. political system, political stability, corruption, crime and violence). Topics also include product and labour markets, infrastructure, trade, financial indicators and composite indices of reform.

Keywords: Structural indicators; economic performance; policy; outcome; governance

JEL Classification: $\mathrm{O} 4$; P50

$$
* * * * *
$$

\section{Un inventaire des indicateurs structurels de politique et de performance}

Ce document passe en revue et évalue en termes de disponibilité, fiabilité et transparence les indicateurs de politiques et de performance qui existent actuellement et sont liés directement ou indirectement à la croissance économique et au niveau de vie. Des indicateurs cherchant à mesurer la situation sociale et politique des pays, de même que des sujets liés à la gouvernance sont examinés (par exemple, le système politique, la corruption, le crime et la violence). Sont aussi couverts les marchés des produits et du travail, les infrastructures, le commerce, les indicateurs financiers et les indicateurs composites de réforme.

Mots Clefs : Indicateurs structurels; performance économique; politique; résultats; gouvernance

Classification JEL : O4; P50

\section{Copyright OECD 2009}

Application for permission to reproduce or translate all; or part of; this material should be made to: Head of Publications Service; OECD; 2 rue André Pascal; 75775 Paris CEDEX 16. 
ECO/WKP(2009)17

\title{
TAKING STOCK OF EXISTING STRUCTURAL POLICY AND OUTCOME INDICATORS
}

\author{
By Davide Furceri and Annabelle Mourougane ${ }^{1}$
}

\section{Introduction}

1. Differences in living standards (generally proxied by income) across OECD countries reflect both different structural policy settings and institutional characteristics. Although there is a broad consensus that institutions and policy stance matter for living standards, these are not always easily captured through reliable and timely structural indicators. In recent years, a large number of indicators have been developed to fill this gap.

2. The last three decades have witnessed an intensive effort, both in the production of policy and outcome indicators and in linking these indicators to economic growth and living standards. This work has contributed to develop a better understanding on growth-enhancing policies, but has sometimes relied on the misuse of these indicators. For this reason, it is useful to undertake an evaluation of these indicators and their potential use in empirical work relating them to growth and living standards.

3. Following and expanding the work by Loayza and Soto (2003), this paper reviews and assesses in terms of availability, reliability and transparency existing policy and outcome indicators that have been used and found to be linked both, directly and indirectly, to economic growth and living standards.

4. In more detail, the focus of the paper is on indicators produced by international organisations (including the OECD), think tanks and researchers. Special attention is given to indicators that are widely used in the literature. Topics include product and labour markets, infrastructure, trade, financial indicators and composite indices of reform are examined. Moreover, indicators aiming at capturing the political and social situation of countries, as well as governance-related issues, are assessed (e.g. political system, political stability, corruption, crime and violence).

5. The rest of the paper is organised as follows. The next section presents a typology of indicators that will be used throughout the paper. The second section reviews existing policy and outcome indicators. Finally, a detailed annex documents the main features of these indicators.

1. The authors are working at the OECD Economics Department. They would like to thank Rüdiger Ahrend, Sven Blondal, Jonathan Coppel, Sean Dougherty, Giuseppe Nicoletti, Joaquim Oliveira Martins and Klaus SchmidtHebbel and other colleagues for helpful discussions and suggestions. They would also like to thank Mika Yamanaka for excellent editorial support. The views expressed in this paper do not necessarily reflect those of the OECD or its member countries. 


\section{Typology of indicators}

6. A wide range of indicators are currently produced by international organisations as well as individual researchers. They differ not only on their time and geographical coverage, but also by their intrinsic nature. Structural indicators can be differentiated according to a number of criteria which are discussed in turn below.

\section{Perception-based versus fact-based}

7. The distinction between perception-based and fact-based indicators is important not least because fact-based indicators are replicable (Table 1). Yet fact-based does not mean objective as these indicators also embody a significant degree of subjectivity (e.g. in the choice of questions). Moreover, assessments of complicated rules are subject to errors of fact and judgement, particularly when the analyst has to determine the net effect of conflicting rules and regulations. Perception-based and fact-based indicators are complementary sources of information. Perception-based information can be internal (results based upon the views of respondents from within the country) or external (results based upon assessments made by non residents of the country).

Table 1. Fact and perception-based measures

\begin{tabular}{lll}
\hline & Fact-based measures & Perception-based measures \\
\hline Advantages & Do not rely on personal judgement & Easier to assemble a database \\
Can be subject to peer review & Answers reflect in part the way \\
Exogenous to economic & regulations are enforced \\
developments occurring at the time & Can cover all level of regulations \\
the data are collected & \\
Free of noise (other than & \\
measurement errors) & \\
Ownership more distinguishable & \\
Require assembling a huge & Rely on personal judgements \\
database and assistance from & Issue of comparability of answers \\
governments and lawyers & between nations (most surveys ask \\
Often only focus on regulation at the & questions that are specific to the \\
national level (problem in federal & country) \\
countries where regulation can be & No control on the type of questions \\
carried out by local governments) & asked \\
& Such measures can not indicate & Context specific \\
certain ground-level features (how & \\
regulations are enforced) & \\
The quantification of regulations & \\
requires the construction and & \\
combination of various types of & \\
indexes raising the questions of how & \\
to code the laws and how to weight & \\
them (entry point for subjectivity) & \\
&
\end{tabular}

\section{Single versus composite indicator}

8. A composite indicator combines different sub-indicators into a single measure. Composite indicators have a number of advantages over single indicators (Table 2). If the same concept is measured by different data sources it is possible to increase the coverage and reliability by combining the sources. A widely cited example is the Governance Matters Reports from the World Bank, which draws together 25 data sources into six composite indicators. The downside of composite indicators is that unless the component data is shown, it is not clear how the rating is derived. Such a lack of clarity weakens the basis for inferring policy prescriptions. In addition all the existing composite indicators fail to capture the 
necessity to ensure coherence amongst various economic policies. In most cases, the composite indicator is simply the aggregation of unrelated sub-indicators and the existing interactions between these variables is ignored. A notable exception is the summary measure of tertiary education set-up developed by Oliveira Martins et al. (2007).

9. The choice of the weights is not straightforward. Weights can be derived either from theory or empirical analysis, usually principal component analysis. Alternatively equal weights could be applied. Although the first alternative is more attractive from an analytical point of view, it is not without drawbacks. Indeed, some indicators have weights varying over time and as a result, the ranking between countries can reflect more a change in weights than a change in policy. Robustness tests run in the context of the re-estimation of the OECD product market regulations suggest that it is preferable to use equal weights in the context of multilateral surveillance process (Woefl et al., 2009).

Table 2: Pros and cons of composite indicators

\begin{tabular}{ll}
\hline Advantages & Reduces multicollinearity \\
& Can summarise complex or multidimensional issues \\
& Easier to interpret than trying to find a trend in many separate indicators \\
& Facilitates the task of ranking countries \\
& Can assess progress of countries over time on complex issues \\
& Reduces the size of a set of indicators or includes more information \\
& Places issues of country performance and progress at the centre of the \\
& policy arena \\
& Facilitates communication with the general public and promotes \\
& accountability \\
\hline Drawbacks & May send misleading policy messages if they are poorly constructed or \\
& misinterpreted \\
& May invite simplistic policy conclusions \\
& May be misused if the construction is not transparent and lacks sound \\
& statistical or conceptual principles \\
& The selection of indicators and weights could be the target of political \\
challenge & May disguise serious failing in some dimensions of policy and increase the \\
difficulty of identifying proper remedial action \\
May lead to inappropriate policies if dimensions of performance that are \\
difficult to measure are ignored.
\end{tabular}

10. Given the complexity of composite indicators, a number of characteristics have been identified to help users and avoid misinterpretation. These relate to : relevance, accuracy, timeliness, accessibility, interpretability and coherence (OECD, 2005).

\section{Policy versus outcome measures}

11. Policy indicators are policy instruments on which policy makers can have a direct impact. However these measures are often an imperfect proxy of the policy lever. Outcome measures capture the country performance in a specific domain and reflect the effects of national policy measures and the international environment. The indicator can be an intermediate, or a final indicator of economic performance. In general reliable and timely measures are available, but policymakers can only influence indirectly such indicators via policy action. 


\section{Review of existing structural indicators}

12. This section reviews the main policy and outcome indicators that are currently produced by international and other organisations. Indicators are discussed by policy topics (See the Annex for a detailed and extensive description of the existing indicators by category).

\section{Governance}

13. The focus on governance has gained prominence over the last decade following the move toward more open markets and less direct governmental control of business activities. Governance can be broadly defined as a system of values, processes, policies and institutions by which a society manages its economic, political and social affairs. However, governance indicators are usually narrowed down to measure specific areas of governance, for instance electoral systems, corruption, human rights, public service provision, civil society, and gender equality.

14. Measuring governance is difficult as this involves many institutions and players. Formal rules can be easily observed, but informal rules are non-observable although they may have a greater influence on the quality of governance and require a deep understanding of the society. Moreover, because the concepts are so broad, the same terms may be used in different ways.

15. Despite these difficulties, a large number of indicators have been constructed in recent years (see Annex) and cover both developed and developing economies. Among the hundreds of indicators that have emerged the most widely-used are policy, composite and perception-based indicators.

\section{Institutional factors}

16. The first strand of governance indicators aims to measure some aspects of good governance through institutional factors. By shaping the economic environment and influencing the behaviour of economic agents, formal and informal institutions impact on long-term growth. They are also associated with good development outcomes, in particular poverty reduction. The World Bank Governance Matters indicators have been pioneers in this area. They are based on expert assessments and surveys on firms and are updated every year. They cover different areas of governance, ranging from the citizens' freedom to political stability and regulatory effectiveness. These indicators are constructed in a way such that their average across all countries is always zero and the standard deviation is always one. As a result, their scale is arbitrary and they can not be used to monitor changes in governance levels for a given country. Moreover, these indicators are subject to very large measurement errors. To address this issue, they are usually reported together with confidence intervals. However, despite all the precautions taken in the publications, these indicators are sometimes misused in comparisons over time or time-series analysis. The World Bank also publishes country information through its country policy and institutional assessment, which are based on the World Bank staff's assessment, but only part of the assessment is publicly available.

17. The composite and sub-indicators of Governance Matters are now widely reported in the press and used in academic research. These indicators are timely and cover a wide range of countries. Transparency in the methodology and in the source used has significantly improved over the years. Since 2006, underlying data from virtually all of the individual data sources are available so that it is possible to replicate the data. 
Table 3 : Correlation between governance indicators and GDP per capita

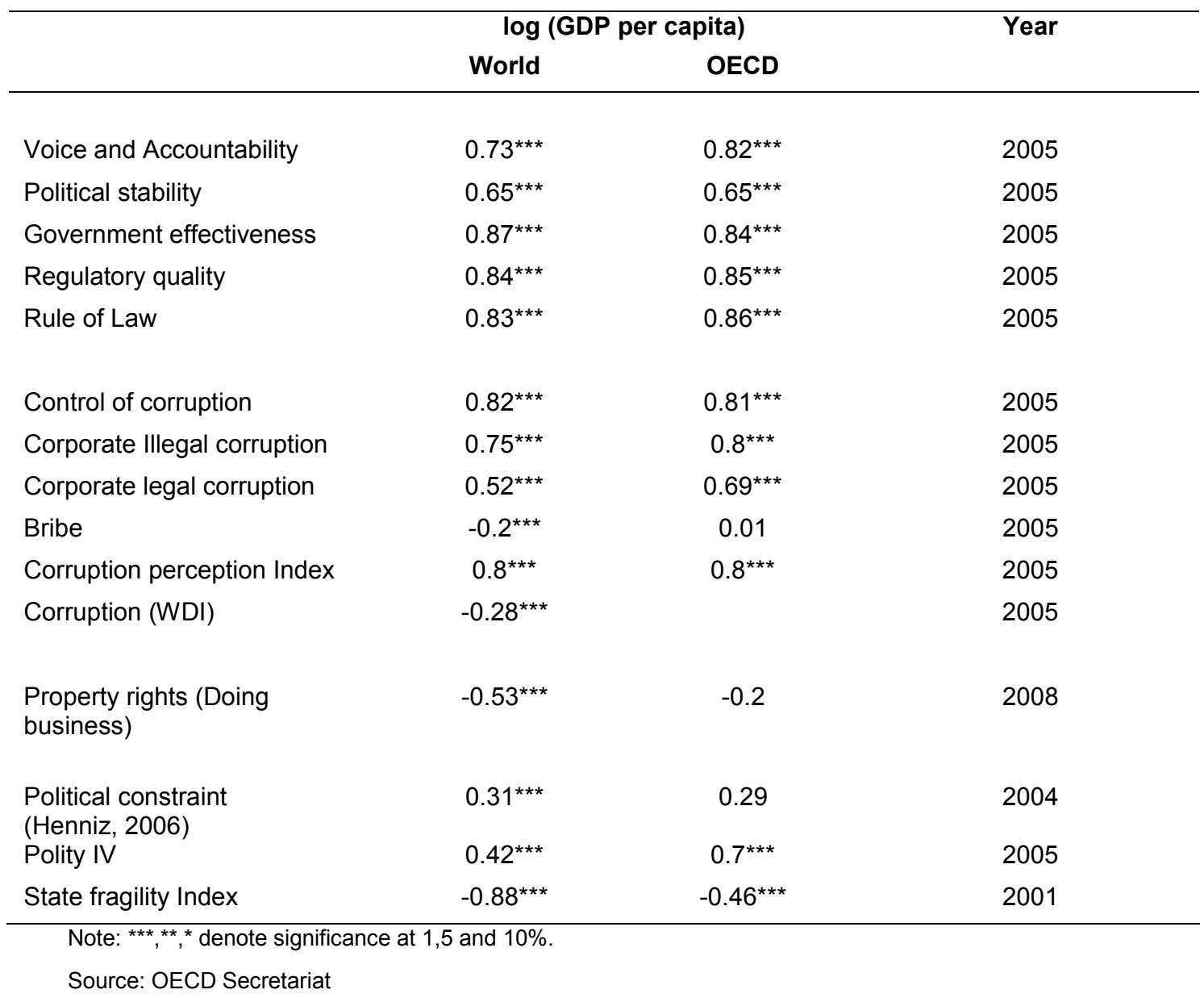

18. Governance indicators are strongly correlated with the current level of national income per capita (Table 3, Figure 1), whether the sample covers the world or is restricted to the OECD. By contrast, correlations between those indicators and GDP per capita growth are much lower, and sometimes not significant. This is consistent with the concepts of absolute and conditional convergence (Barro and Sala-iMartin, 1991; Sala-i-Martin, 1995, Furceri, 2006).

19. As the amplitude of the correlation is similar across different indicators, it may be sufficient to focus on one dimension of institutional governance. ${ }^{2}$

2. An alternative would be to construct a summary measure, but this would raise the issue of interpretation and choice of weights. 
Figure 1: Correlation between selected Governance Matters indicators and GDP per capita

World 2005, correlation $=0.73^{* * *}$

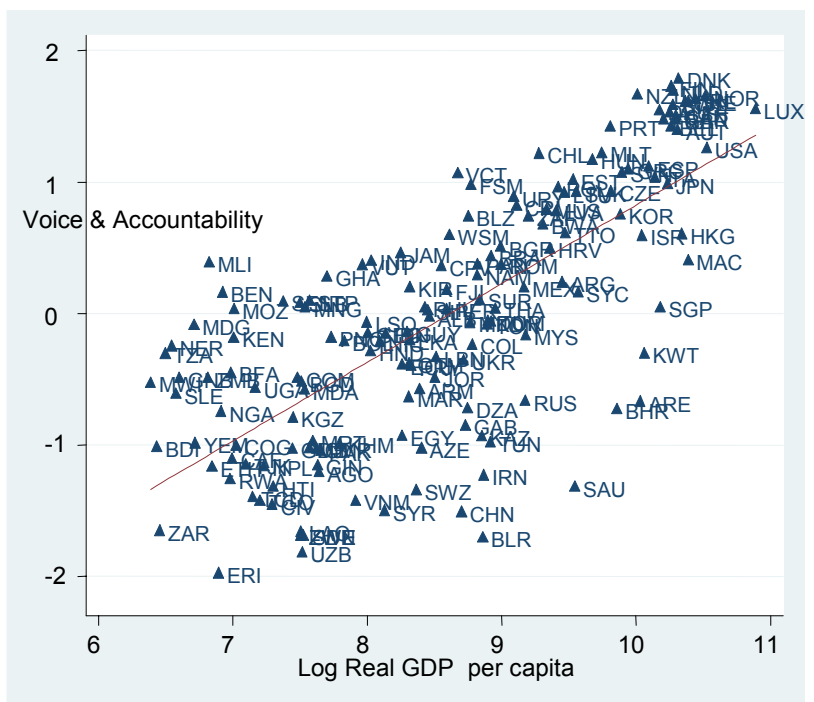

World 2005, correlation $=0.65^{\star * *}$

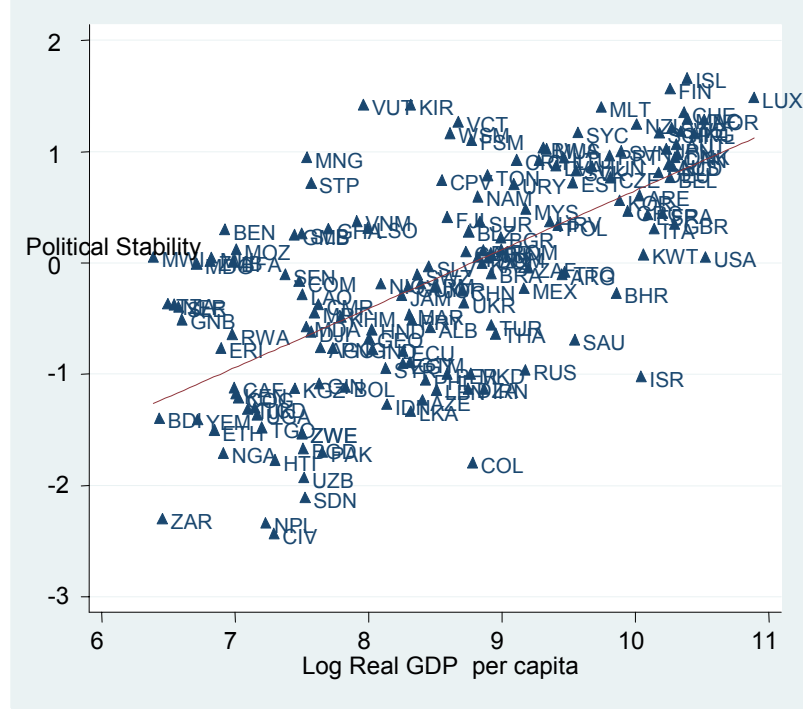

OECD 2005, correlation $=0.82^{\star \star *}$

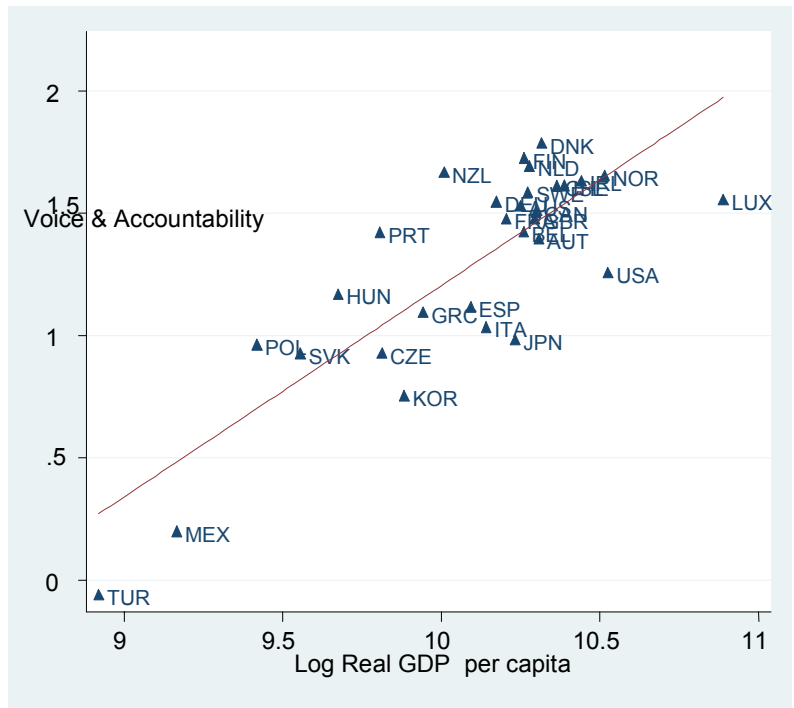

OECD 2005, correlation $=0.65^{* * *}$

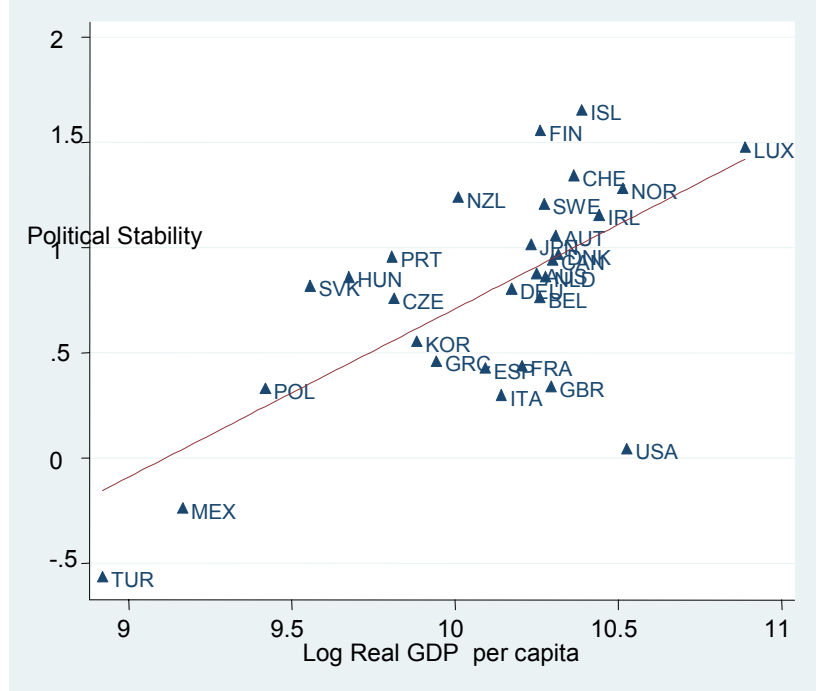


World 2005, correlation $=0.87^{\star * *}$

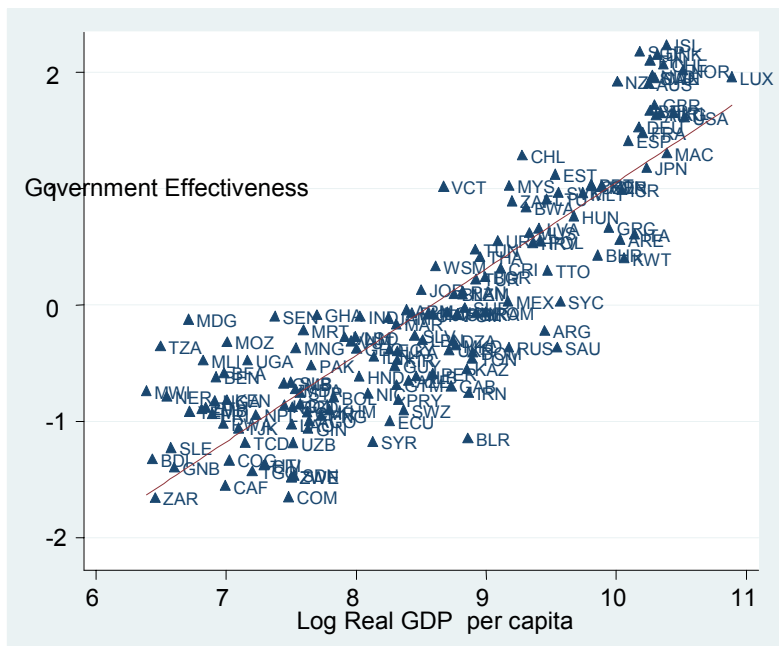

World 2005, correlation $=0.84^{\star \star *}$

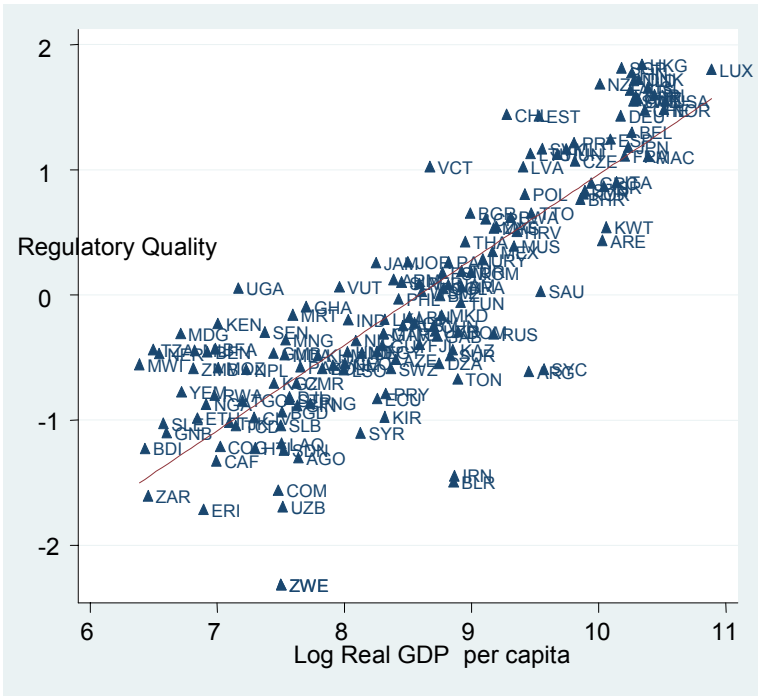

OECD 2005, correlation $=0.84^{* * *}$

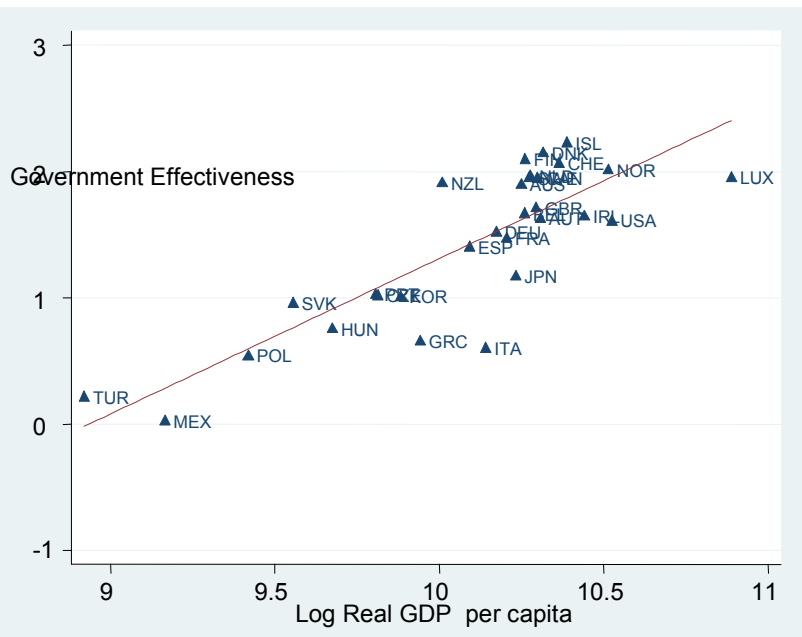

OECD 2005,

correlation $=0.85^{* * *}$

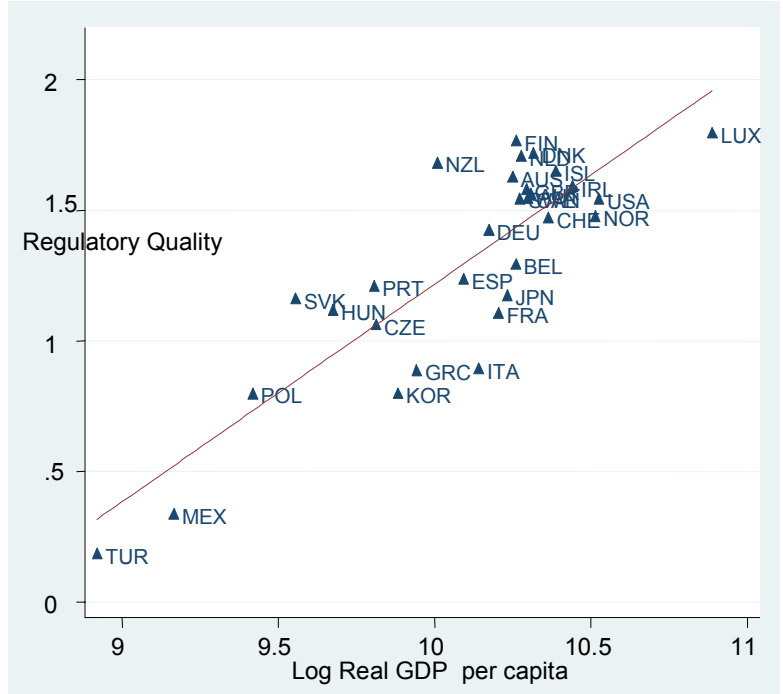



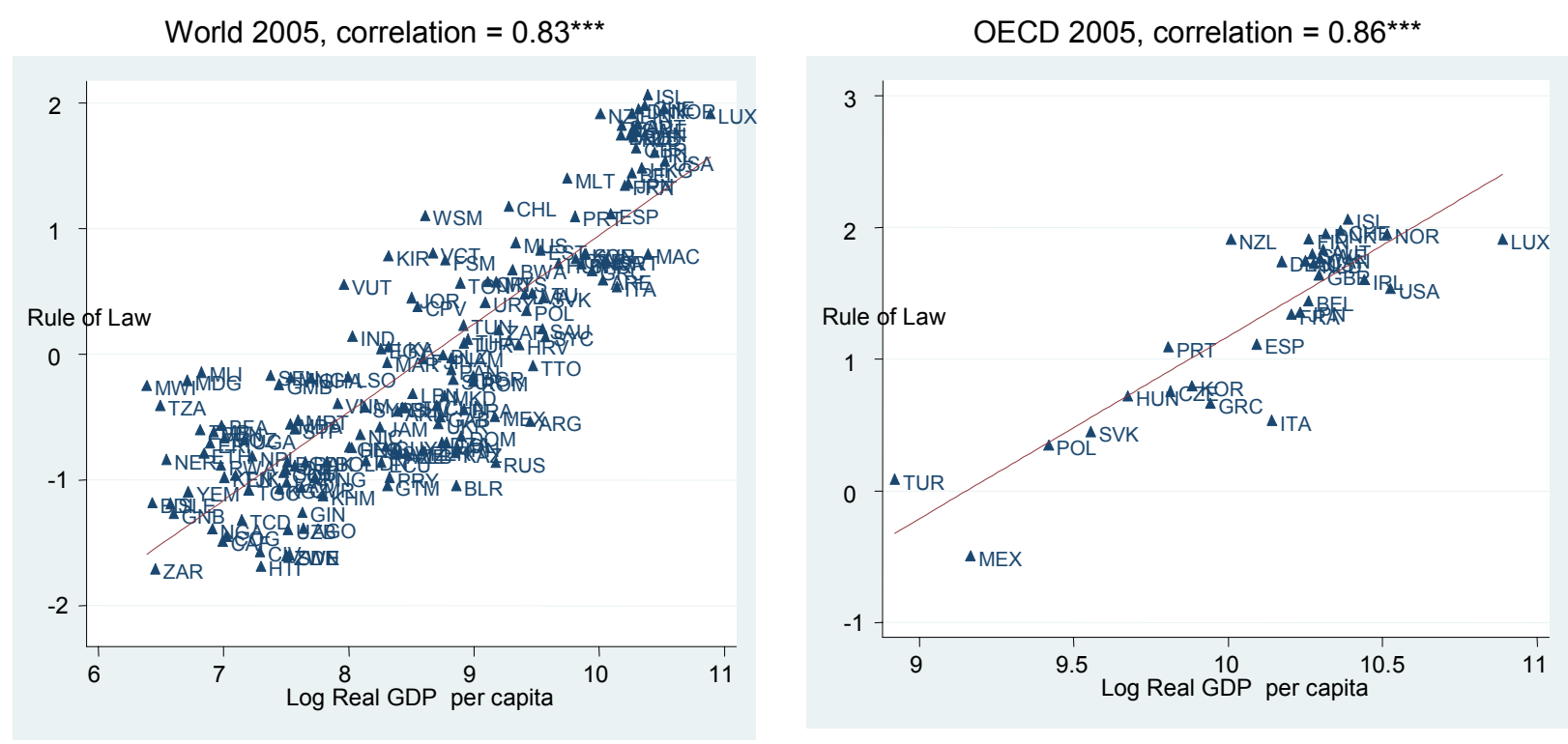

Note: ${ }^{* * *},{ }^{* *},{ }^{*}$ denote significance at 1,5 and $10 \%$.

Source: World Bank.

20. However, the use of these indicators can be questioned on a number of grounds (Arndt and Oman, 2006):

- The indicators are inherently subjective and not grounded in theory. As a result the same indicator can lead to very different interpretations.

- The data rely on a large variety of sources consisting of surveys of firms and individuals, as well as the assessments of commercial risk rating agencies, non-governmental organisations, and a number of multilateral aid agencies and other public sector organisations. The reliability of these sources is variable. In total the dataset draws on 33 sources.

- The indicators embody large measurement errors. For some developing countries, the indicator relies on a limited number of surveys, increasing further the risk of measurement error. To partially address these issues, confidence intervals around the main World Bank indicators are published. A change in an indicator over time is only significant when the confidence intervals of the new and old indicator do not overlap.

- The indicators do not permit the identification of trends over time. The changing composition of many of the indicators over time means that the indicator can not be reliably used to compare levels of governance over time in a given country or among countries. This implies that monitoring of progress over time is not possible.

- The aggregation procedure assigns less weight to the sources that are less correlated with other sources. Typically more weight is given to expert assessment and firm surveys than to population surveys which carry often no weight. This suggests that measurement errors are uncorrelated across sources and is a questionable assumption. Moreover weights attributed to different sources vary between countries, lowering cross-country comparability. 
ECO/WKP(2009)17

\section{Public finances and tax}

21. Given the size of government and its role in the economy, the contribution of government to national economic growth is of great significance (Folster and Henrekson, 2001; Alfonso and Furceri, 2008). Moreover transparent budgeting institutions foster debate between different alternative policies. However, there are few reliable sources of comparative public management data. To fill this gap, the OECD will publish a bi-annual Government at a Glance publication, starting in 2009. Information on the budget process, decentralisation, public sector efficiency have been gathered through questionnaires collected by the OECD. In addition, composite indicators measuring compliance with OECD good practice for the quality of regulatory management systems according to 16 dimensions. The indicators rely on a principal component analysis using 1998 and 2005 data and have then been interpolated to cover the period 1998-2006. The data will be updated using the 2008 questionnaire. Data are available for all OECD countries except Luxembourg, Poland and Slovakia and are subject to peer review. The first component of the principal component analysis gathers information on institution, tool and capacity building, and preliminary results suggest that this indicator is well-correlated with economic outcomes such as employment, GDP or labour productivity.

22. Another promising project to measure the quality of public finances along several dimensions is underway at the European Commission. Some composite measures have also been developed by the centre of budget and policy priorities (open budget index) and the Heritage Foundation (fiscal freedom) but their simplicity renders their interpretation difficult. Lastly, the World Bank has constructed a perception-based indicator of government effectiveness in its Governance Matters publication.

23. The structure of tax systems also matters for growth (Johansson et al., 2008; Arnold, 2008). A lot of data are available on the structure of the tax system, its efficiency and its redistributive impact (at least for some types of tax) in OECD publications. Updated information on the level and the structure of tax is available in Tax and Benefit and in Revenue Statistics for OECD countries. This includes standard data on corporate, income or consumption tax revenue and rates. More sophisticated indices such as the Cefficiency index, which seeks to capture the efficiency of consumption taxes are also constructed at the OECD. Information on tax rates can also be found in the OECD Tax database, but the country coverage is usually limited and corporate rates are only available for specific groups of firms.

\section{Property rights}

24. (Intellectual) property rights refer to the degree to which (intellectual) private property is protected by institutions and policy. Strong perceived property rights encourage firms to invest, but at the same time may slowdown the diffusion of technology. The overall effect on investment remains an empirical question. Moreover the cost of reforming property rights can be high and slow the reform process. Several measures of property rights are available. The first indicator was developed by Ginarte and Park (1997). The Heritage Foundation index is the most widely used and is an assessment of the degree to which the country protects property rights and facilitates private contracting. Other indicators of property rights are commonly used in the literature, such as the indicator of protection against the risk of expropriation from the International Country Guide Risk. An indicator of investor protection is also available in the World Bank's Doing Business database. This indicator is updated every year and covers a large number of countries and is based on official or quasi-official sources. The data are also subject to peer review. It is correlated with the level of GDP per capita, but the coefficient of correlation is small, especially when the analysis is restricted to the group of OECD countries (Figure 2). In addition, the Doing Business database focus on specific geographical areas, and types of firms and may thus not be fully representative of property rights at the national level. 


\section{Political institutions}

25. Political institutions, including the type of regime or the electoral system through their effect on the country political stability and or government spending, are also crucial in investment decisions and long-term growth. Coding on the form of government and measure of government stability are currently available in many databases. In particular, the Polity IV project and the World Bank database of political institutions gather updated information on a large set of countries. Other frequently indicators cover civil and political rights and are based on expert assessments.

\section{Figure 2: Correlation between Doing business property right and GDP per capita}
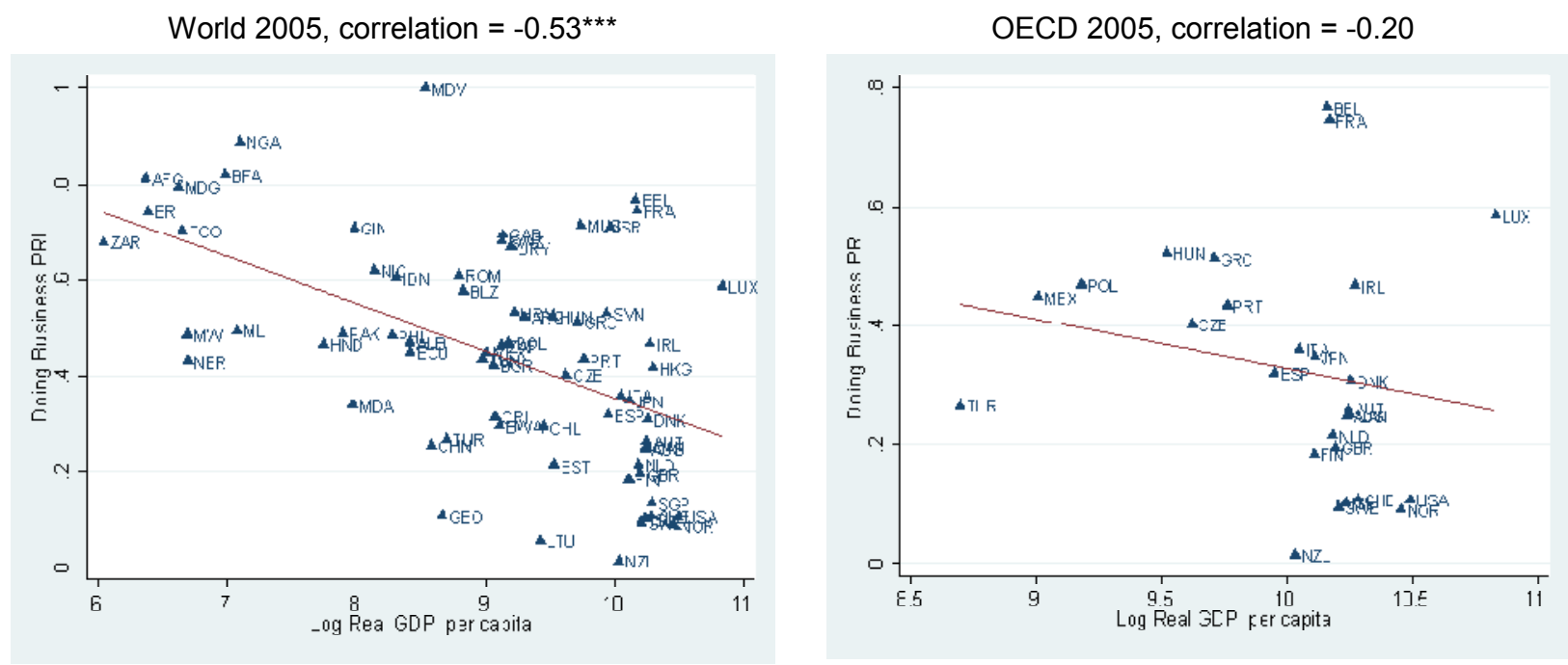

Note: ${ }^{* * *},{ }^{* *},{ }^{*}$ denote significance at 1,5 and $10 \%$.

Source: World Bank.

26. The Polity IV dataset has a broad geographical and temporal scope. The correlation with the level of GDP per capita for countries is significant but not high. Each annual update of the Polity data series includes a systematic re-examination of country coding over the previous five years and a review of cases that have raised concerns and resulted in specific inquiries by data users. The underlying methodology is transparent. The construction of the overall Polity IV indicator ultimately relies on points which are assigned to qualify certain features of the political system (e.g. on competitiveness of executive recruitment). This has the benefit of ensuring an equal treatment across countries and comparability over time, but also means the weights are arbitrarily imposed.

27. The World Bank's Database on Political Institutions dataset contains objective information on different feature of the political system and electoral rules. It is based on official sources. The more aggregate variable in this database codes the political regime using only three categories: direct presidential, strong president elected by assembly and parliamentary. This indicator may not be sufficiently precise to help discriminating between political systems in OECD countries (Figure 3).

\section{Corruption}

28. Another strand of governance indicators have sought to measure corruption, i.e. the abuse of public office for private gains. This is an outcome of poor governance. It is found to influence a number of fundamental economic aggregates (Lambsdorff, 1999). In particular, corruption discourages private investment and distorts resource allocation. Reducing corruption is also found to have positive side effects 
such as increasing the effectiveness of public spending. But measuring corruption is difficult, as those with direct knowledge of corruption are likely to keep silent on it. In particular, the extent to which political decisions are influenced by corruption is very difficult to estimate as it lies outside the direct experience of citizens and small businesses.

Figure 3: Correlation between Polity IV political indicator and GDP per capita
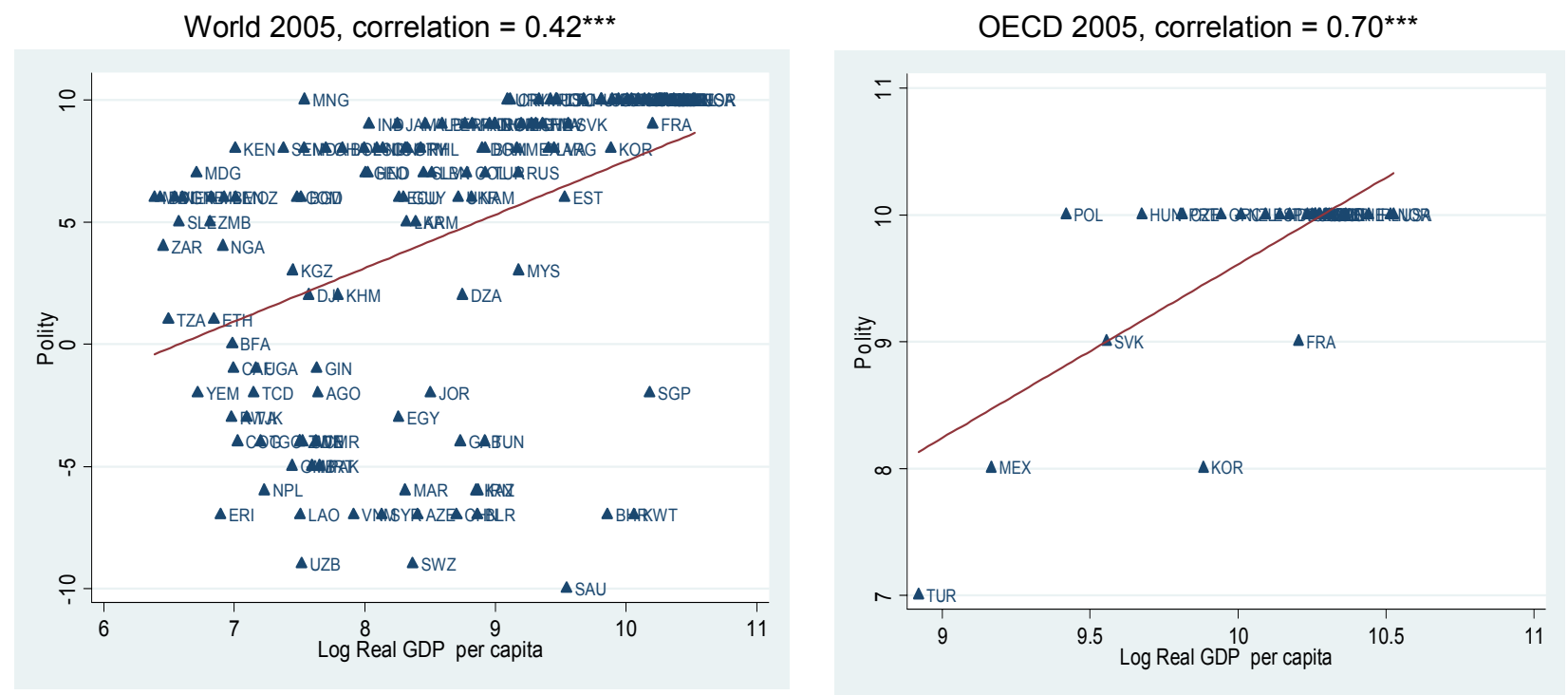

Note: ${ }^{* * *}, * *,{ }^{*}$ denote significance at 1,5 and $10 \%$.

Source: Polity IV project and World Bank.

29. A wide range of perception-based corruption indicators are currently available, using information from expert and business surveys. Two indicators are worth mentioning: the Corruption Perception Index (CPI) from Transparency International and the control of corruption index from Governance Matters. In response to the criticism that corruption indicators underestimate the extent of corruption in developed economies, Kaufmann et al. (2008) have also assessed the importance of legal ${ }^{3}$ and illegal corruption. Both the CPI and the control of corruption indicators are timely and appear well correlated with the level of GDP per capita, although clear income threshold effects are visible (Figure 4). The control of corruption index suffers nonetheless from the same limitations as the other indicators of Governance Matters (see above).

30. The corruption perception index from Transparency International is probably the most widely used and the one with the broadest geographical coverage, though the coverage can vary overtime. It is a subjective index. Despite its label, this indicator does not measure the actual level of corruption, but provides a country ranking according to the degree of perceived corruption among public officials and politicians. The indicator is published together with standard errors, casting some light on the uncertainties surrounding the data. Information on its methodology and sources is easily accessible. However, the measure lacks consistency over time. The sources used for the CPI is indeed sometimes discontinued over the years with no reason and even though the source is available: only two sources have been used in every years the index has been published. It is also difficult to interpret the year-on-year change of score in the CPI which could reflect the fact that different points of views have been collected and different questions asked rather than a change in the reality of corruption in a country. According to Transparency

3. Legal corruption is corruption that is undertaken within the legal framework. 
International, the CPI measure is a ranking that can not be used as a measure of corruption: indeed it emphasised the rank ordering of countries over internal reforms in countries. This means that this indicator can not be used as an indicator of reform effort. In addition, this indicator suffers from selection bias (OECD, 2006). Finally the indicator draws on 12 sources, with different degrees of reliability.

Figure 4: Correlation between selected indicators of corruption and GDP per capita
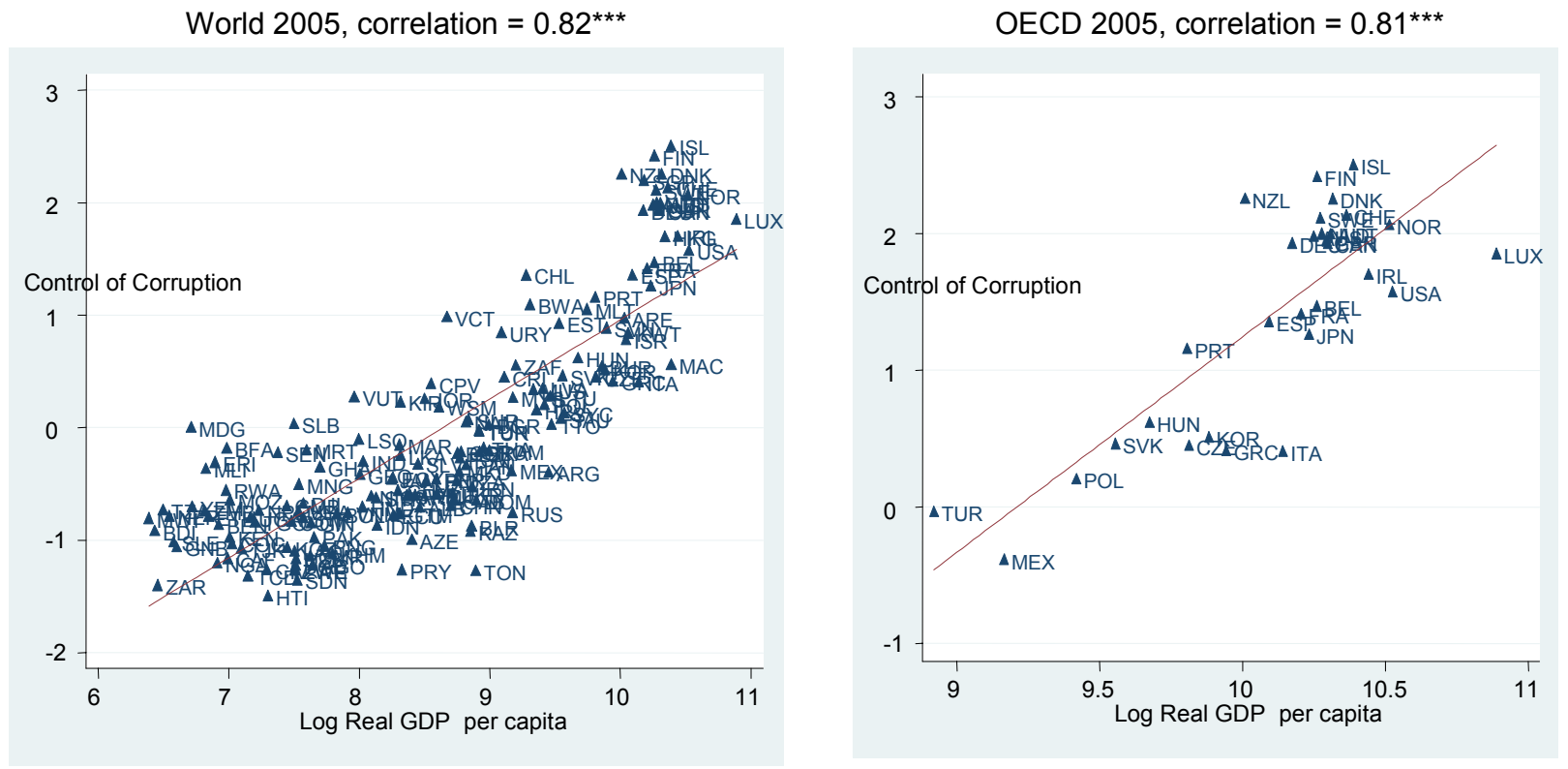

World 2005, correlation $=0.80^{\star * *}$
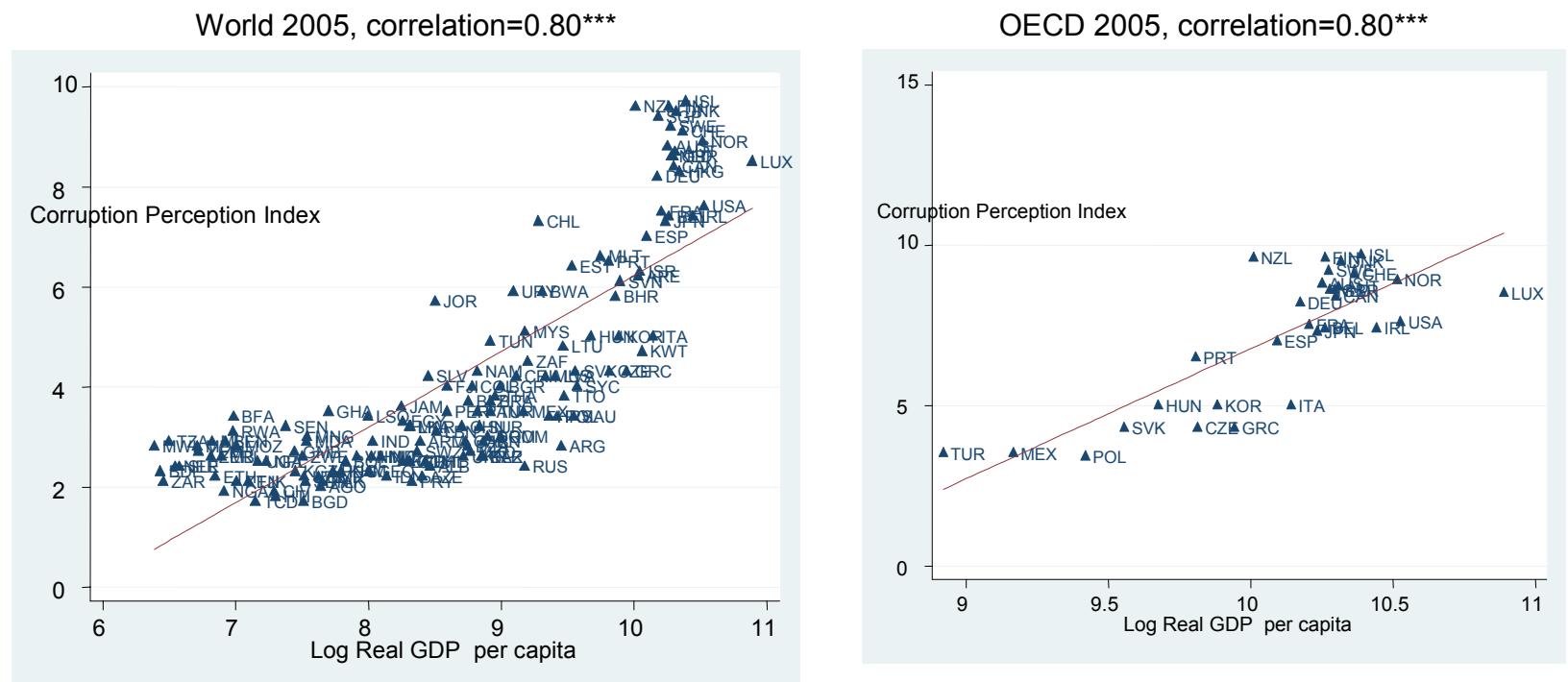

Note: ${ }^{* * *},{ }^{* *},{ }^{*}$ denote significance at 1,5 and $10 \%$.

Source: World Bank, Transparency International. 


\section{Link with economic performance}

31. The link between selected governance indicators and economic growth, or other measures of economic performance has been examined in depth (Easterly, 2005). In general, high quality governance institutions are found to matter for economic performance (Table 4). However, the direction of causality is not always clear: 'deep' institutions are also highly endogenous, and it is not at all easy to identify their causal role with respect to income levels or economic growth (Glaeser et al., 2004; Acemoglu et al., 2005). Moreover, the role of geographic factors and trade openness appears to be closely inter-related with institutions, making their identification difficult (Rodrick et al., 2004; Boulhol and de Serres., 2008). In addition, there appear to be important threshold effects, with good institutions (e.g. the absence of corruption) having very little effect at the two extremes of the income scale. Finally, it should be noted that the nature and limits of composite governance indicators are not always fully grasped by users, weakening the rigour and credibility of many studies. In addition, the results found in the literature are usually sensitive to changes in the econometric model used, and to the variables included and the underlying assumptions.

Table 4. Governance and economic growth

\section{Indicator or methodology and main results}

\section{Institutional factors}

North $(1990,2005)$

Globerman and Shapiro (2002)

Kaufmann and Kraay (2002)

Kaufmann et al. ( 2008)

Johansson et al (2008)

\section{Property rights}

Jaumotte and Pain (2005)

Knack and Keefer (1995);Mauro (1995); Acemoglu, Johnson and Robinson ( 2001)

Political factors

Przeworski et al (2000)

Persson and Tabellini (2004)

Persson and Tabellini (2003)
Indicator: Formal and informal institutions (culture and unwritten values) The paper demonstrates the importance of a system of governance and their interaction with the behaviour of economic and political organisations for longterm economic growth, enhancement of human welfare and societal development. Indicator: Aggregate of the 6 Governance Matters indicators Countries that fail to achieve a minimum threshold of effective governance are unlikely to receive much FDI, and above that threshold the quality of governance infrastructure is an important determinant of the amount received. Indicator: 6 Governance Matters indicators

Good governance tends to promote growth. However growth, per se, does not tend to promote better governance.

Institutions appear to play an important role in economic development, and countries with higher levels of GDP per capita have much higher quality institutions according to many measures.

Methodology: Macro and micro-based analysis

The structure of the tax system has an impact on growth.

Indicator: Cross-country index of intellectual property rights developed in Ginarte and Park (1997) and updated in Park and Singh (2002).

Intellectual property rights have little effect on R\&D spending.

Less secure property rights are correlated with lower aggregate investment and slower economic growth.

Indicator: Use objective criteria for distinguishing on a yearly basis between democratic and non-democratic governments (with 2 sub-categories: authoritarian and bureaucratic dictatorship) for 141 countries between 1950 and 1990.

Democratic and non-democratic governments tend to grow on average at the same rate, but population grows faster in non democraties so that GDP per capita grow more rapidly in democraties. Existence of a poverty trap: in the poorest countries, democracy makes no difference to economic growth. Constitutional rules shape economy policy. Methodology: Panel data from 1960 covering about 500 elections in over 50 
$\mathrm{ECO} / \mathrm{WKP}(2009) 17$

Milesi-Ferretti, Perotti and Rostagno (2002) ;Persson and Tabellini (2003, 2004)

Gradstein (2008)

Marshall and Cole (2008)

\section{Corruption}

Lambsdorff (1999)

Kraay and Nehru (2004)

Welsh (2008)

Kaufmann et al. (2008) democracies.

A broad classification of electoral rules into proportional and majoritarian does not seem to be strongly correlated with economic performance. It appears nonetheless that a parliamentary form of government is associated with better performance and better growth promoting policies, measured by indexes for broad protection of property rights and of open borders in trade and finance. The negative effect of presidentialism is only present among the democracies with lowest scores for the quality of democracy;

The authors classify countries in two groups according to the electoral formula and estimate the extent of electoral cycles in different specifications, including fixed country and time effects as well as a number of time-varying regressors. Governments in democracies that use plurality rule cut taxes, and government spending during election years-the magnitude of both cuts is of the order of 0.5 percent of GDP. In proportional representation democracies, tax cuts are less pronounced, and no spending cuts are observed.

Relying on different data, these papers show that a statistically significant (but smaller) effect of the electoral systems remains after controlling for other determinants of social security and welfare spending, such as the percentage of the elderly in the population, per capita income, the age and quality of democracy.

Method: Theoretical model

Low-quality institutions, concentration of political power and material wealth and underdevelopment are persistent over time. The possibility of two developmental paths is exhibited: with concentration of political and economic power, low-quality institutions, and slow growth; and a more equal distribution of political and economic resources, high-quality institutions, and faster growth.

Indicator of state fragility

A fairly strong relationship is found between income and the fragility of states in the global system. However, a wide variance in fragility scores at any level of incomes is also observed.

Method: Overview of the literature

Corruption affects a variety of economic indicators such as government expenditures, total investment, capital flows and foreign direct investment, international trade, foreign aid and GDP per capita.

Indicator: CPIA indicators from 1997 to 2001

Significant inverse correlation between the quality of a country's institutions and probability of debt distress

Indicator: Transparency International average perceived corruption indicators This article uses self-rated subjective well-being as an empirical approximation to general welfare and shows that cross-national welfare is affected by corruption not only indirectly through GDP, but also directly through non-material factors.

Indicator of legal corruption

Governance and corruption issues are key constraints to investment and business and are particularly significant in assessing country's overall positions

Source: OECD Secretariat

\section{Society}

Health

32. Health can affect growth through several channels. First, health affects labour productivity, since healthier workers can work harder and for a longer period of time. Second, health favours human capital accumulation, since healthier students on average have higher cognitive functioning. Third, health encourages physical capital accumulation, since healthier workers that work for a longer period of time 
increases saving (for retirement) and thus investment, and since the increase in labour input from healthier workers will increase the marginal product of capital. Fourth, health influences population growth.

33. Health indicators can be subdivided into policy and outcome indicators. Health policy indicators are a combination of health care resources, lifestyle and socio-economic factors. Health care resources usually are separated into monetary (public spending on health) and non-monetary resources (number of physicians, hospitals, medical machinery, etc). While from a theoretical point of view health care resources are positively linked to health outcome indicators, the evidence is not conclusive from an empirical point of view ${ }^{4}$. In contrast, socio-economic factors (such as education) and lifestyle factors (tobacco, alcohol and nutrition) have been found to be strongly related to health outcomes. Data on health policy indicators are easily accessible and can be used to assess their impact on health outcomes (see Annex). However, they suffer from endogeneity problems in relation to outcome indicators and GDP growth. Thereby, they have to be used very carefully in that context.

34. Outcome indicators aim to measure health outcomes. Those that have been usually considered in the literature are: mortality/longevity indicators (life expectancy at various ages), mortality indicators adjusted for the presence of a particular disease and quality of life, and other health-related indicators, such as public satisfaction for the health care system ${ }^{5}$. Different international organisations such as OECD, World Health Organization and World Bank publish data on many of these outcome indicators, and data are available for a long time span. The variable that has been mostly used in the literature on health and growth is a performance measure, life expectancy at birth. Data on life expectancy are available from official sources (OECD, IMF, World Bank) and over a large time span and for a broad set of countries.

35. These indicators have been found in many studies to be positively linked to GDP per capita, GDP growth and TFP growth, although it is unclear in which direction the causality goes (Table 5). ${ }^{6}$ On the one hand, life expectancy at birth clearly improves when living standards increase, on the other hand life expectancy at birth can raise incentives to invest in education and increases labour supply if it extends the working life. The latter effect could be particularly important in economies where the population is ageing rapidly. Although micro studies based on individual and household data found a positive link between health outcomes and economic performance, the evidence of a link at the aggregate level is much less clear for developed countries (Price et al. 2008; Dormont et al. 2008). The weaker evidence found for developed countries could be due to a non-linear relationship, positive at low levels of development and insignificant or negative at higher levels. Moreover, it should be noted that the use of these indicators to assess the impact on growth has to be dealt with carefully, since problems of endogeneity and omitted variables bias may arise.

4. See for example, Berger and Messer (2002), Self and Grabowski (2003), Soares et al. (2007), Joumard et al. (2008).

5. See Joumard et al. (2008).

6. See Bloom et al. (2004) and Jamison et al. (2005) for a review of studies assessing the impact of health on economic growth. 
ECO/WKP(2009)17

Table 5: Selected results on health and economic performance

\begin{tabular}{|c|c|}
\hline & Indicator or methodology and main results \\
\hline \multirow[t]{2}{*}{ Barro (1996) } & $\begin{array}{l}\text { Indicator: Life expectancy } \\
\text { Main result: The paper showa significant effects of health on growh for a panel } \\
\text { of } 84 \text { countries from } 1965 \text { to } 1990 \text {. }\end{array}$ \\
\hline & $\begin{array}{l}\text { Methodology: 3SLS; controlling for human capital and other covariates. } \\
\text { Indicator: Life expectancy }\end{array}$ \\
\hline \multirow[t]{2}{*}{ Barro and Lee (1994) } & $\begin{array}{l}\text { Main result: The paper show significant effects of health on growh for a panel } \\
\text { of } 90 \text { countries from } 1965 \text { to } 1985 \text {. }\end{array}$ \\
\hline & $\begin{array}{l}\text { Methodology: SUR and random effects; controlling for human capital and } \\
\text { other covariates. } \\
\text { Indicator: Life expectancy }\end{array}$ \\
\hline \multirow[t]{2}{*}{ Barro and Sala-i-Martin (1995) } & $\begin{array}{l}\text { Main result: The paper shows significant effects of health on growh for a panel } \\
\text { of } 90 \text { countries from } 1965 \text { to } 1985 \text {. }\end{array}$ \\
\hline & $\begin{array}{l}\text { Methodology: SUR and random effects; controlling for human capital and } \\
\text { other growth and governance covariates. } \\
\text { Indicator: Adult survival rate }\end{array}$ \\
\hline \multirow[t]{3}{*}{$\begin{array}{l}\text { Bhargava, Jamison, } \\
\text { Lau, and Murray (2001) }\end{array}$} & $\begin{array}{l}\text { Main result: The paper show significant effects of health on growth for a panel } \\
\text { of } 92 \text { countries from } 1965 \text { to } 1990 \text {. }\end{array}$ \\
\hline & $\begin{array}{l}\text { Methodology: Dynamic random effects; controlling for fertility and other growth } \\
\text { covariates. }\end{array}$ \\
\hline & Indicator: Life expectancy \\
\hline $\begin{array}{l}\text { Bloom, Canning, } \\
\text { and Malaney (2000) }\end{array}$ & $\begin{array}{l}\text { Main result: The paper shows significant effects of health on growth for a } \\
\text { panel of } 92 \text { countries from } 1965 \text { to } 1990 .\end{array}$ \\
\hline
\end{tabular}

Methodology: Pooled OLS; controlling for working age and growth covariates. Indicator: Life expectancy

Bloom and Williamson (1998)

Main result: The paper shows significant effects of health on growth for a panel of 78 countries from 1965 to 1990.

Methodology: Pooled OLS; controlling for growth covariates Indicator: Life expectancy

Caselli, Esquivel and Lefort (1996)

Main result: The paper shows significant effects of health on growth for a panel of 91 countries from 1960 to 1985.

Methodology: GMM; controlling for human capital Indicator: Adult mortality

Finlay (2007)

Main result: The paper shows significant effects of health on growth for a panel of 62 countries from 1960 to 2000.

Methodology: 2SLS; controlling for human capital, fertility and other growth covariates

Indicator: Life expectancy

Gallup and Sachs (2000)

Main result: The paper shows significant effects of health on growth for a panel of 91 countries from 1960 to 1985.

Methodology: GMM; controlling for human capital

Indicator: Life expectancy and life expectancy squared

Sachs and Warner (1997)

Main result: The paper shows significant effects of health on growth for a 
panel of 97 countries from 1965 to 1990.

Methodology: OLS; controlling for human capital, governance and growth covariates.

Suhrcke and Urban (2006)

Indicator: Cardio-vascular disease

Main result: The paper shows significant effects of health on growth for a panel of 74 countries from 1960 to 2000 , especially for rich countries. Methodology: GMM; controlling for growth covariates.

Source: OECD Secretariat

Figure 5: Correlation between life expectancy and GDP per capita

World 2005, correlation $=0.80^{* * *}$

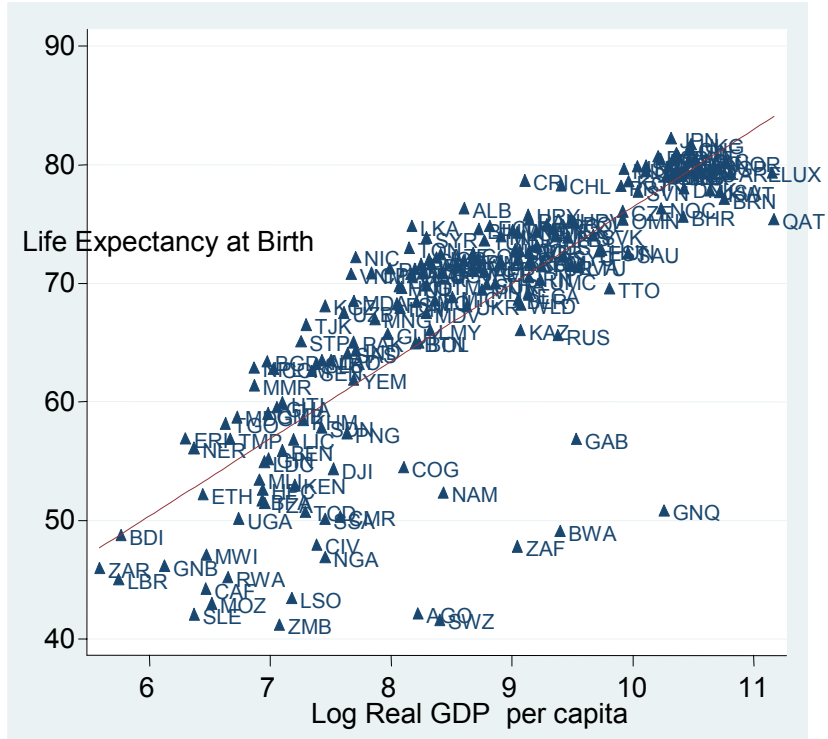

Note: ${ }^{* * *}, * *,{ }^{*}$ denote significance at 1,5 and $10 \%$.
OECD, 2005, correlation $=0.70^{\star * *}$

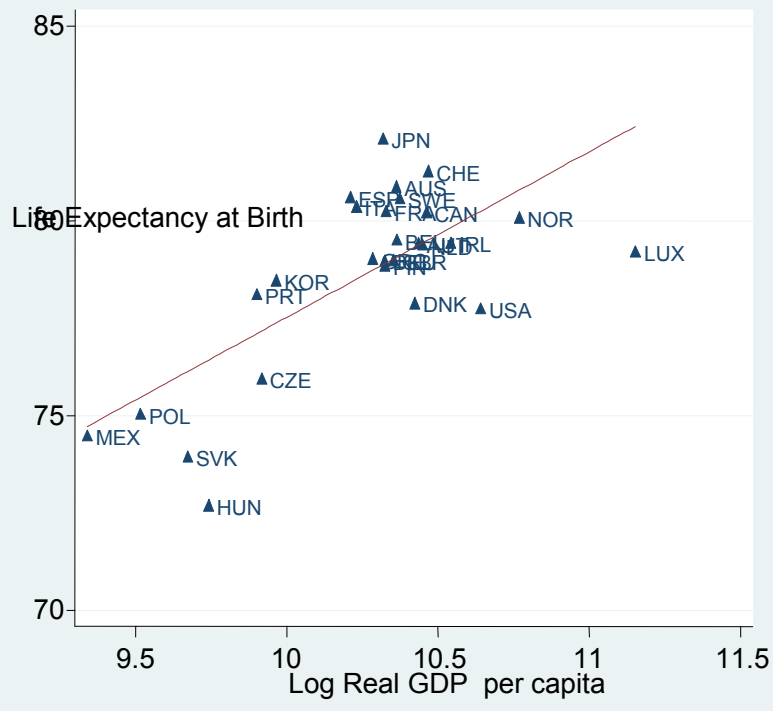

Source: World Bank, OECD.

\section{Education}

36. Investment in human capital at all ages is crucial for long term growth and is often considered as a pre-requisite to development (Table 6). 
$\mathrm{ECO} / \mathrm{WKP}(2009) 17$

Table 6: Selected results on education and economic performance

\begin{tabular}{ll}
\hline & Results \\
\hline $\begin{array}{l}\text { Barro (1991), Mankiw et al } \\
\text { Barro (1997) }\end{array}$ & Educational factors have a positive impact on output levels \\
Toppel (1999), Oulton (1997) & $\begin{array}{l}\text { An extra year of education raises economic growth by } 1.2 \% \\
\text { per annum }\end{array}$ \\
$\begin{array}{l}\text { The impat of an extra year of schooling is much smaller than } \\
\text { in Barro (1997) }\end{array}$ \\
An additional year of schooling increases wage by around \\
Krueger and Lindhal (2001) & $\begin{array}{l}\text { Find a significant effect of education on growth only for } \\
\text { countries with the lowest level of education }\end{array}$ \\
Cohen and Soto (2001), de la & $\begin{array}{l}\text { Schooling indicators have an impact in standard growth } \\
\text { specifications }\end{array}$ \\
Fuentes and Domenech (2006) & $\begin{array}{l}\text { Using indicator of skills, the effect of education on output is } \\
\text { found to be stronger than those estimated using attainment } \\
\text { Hanuchek and Kimbo (2001); }\end{array}$ \\
Coulombe (2004) &
\end{tabular}

37. Data on early education and childcare are available in the OECD Family database, though it is mostly limited to childcare support, public spending on childcare or enrollments. No indication on the quality of the services is currently available on a cross-country basis.

38. For primary and secondary education, the OECD Education at a Glance database is a rich source of information and is updated every year. This data can be complemented by UNESCO data for non OECD countries. In addition the PISA score, which is based on series of tests passed by 15 -year old students, is now regularly published for different topics. The aggregate score is found to be well correlated with the level of GDP per capita, especially when developed countries are incorporated in the sample (Figure 6).

39. Investment in tertiary education is usually measured through indicators of education output (and not quality) such as enrollment, literacy, graduation ratios or the number of years of schooling. The main difficulty in using this data is generally their lack of comparability across countries. Harmonised graduation ratios have been produced by the OECD and UNESCO. Consistent time series for a relatively long period (usually 1991-2004) can be derived by combining these two sources. Data on international student enrollments can also be found in the UNESCO-OECD-Eurostat (UOE) data collection on education statistics. In addition, composite indicators have been built to measure supply-side factors, such as a summary measure of the institutional set-up of tertiary education, or demand-side factors such as the internal rate of return to education (Oliveira Martins et al., 2007). These data are available for many OECD countries, but only for some years (2005-2006 for the supply-side indicator and 2001 for the internal rate of return). 
Figure 6: Correlation between PISA scores and GDP per capita
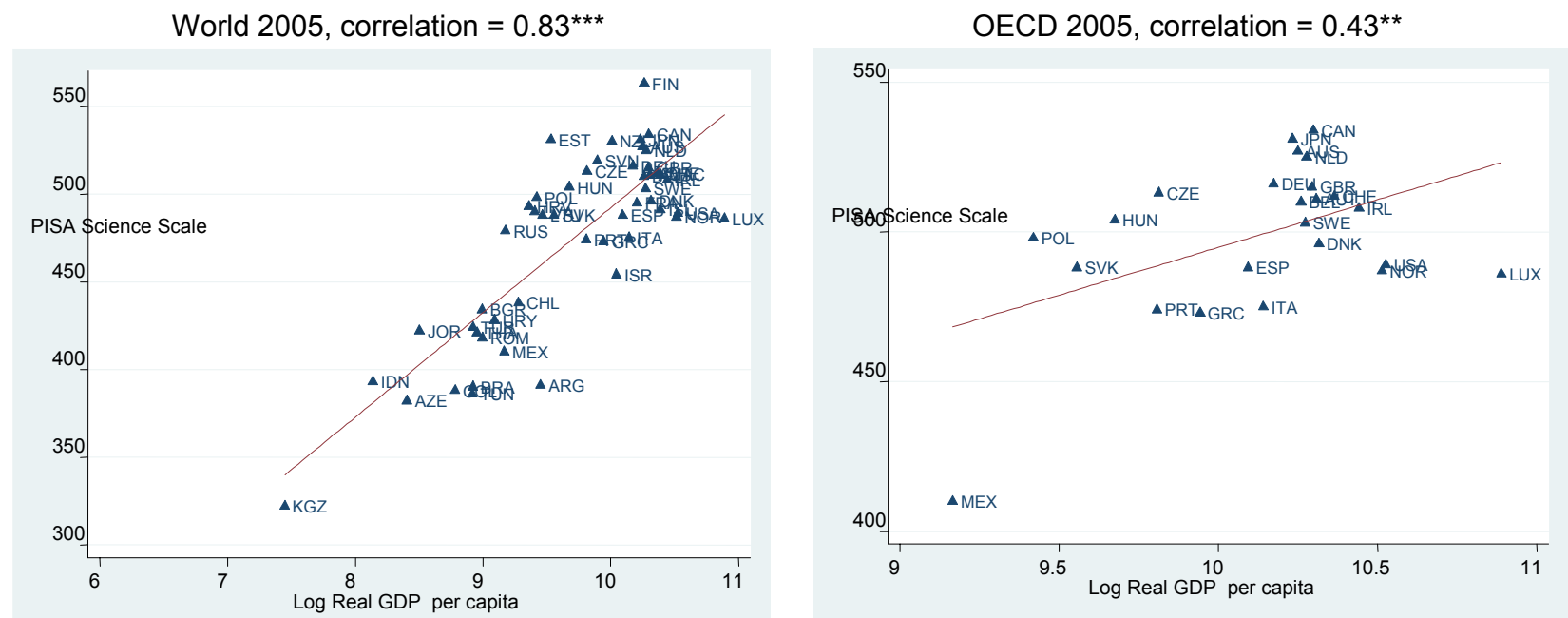

Note: ${ }^{* * *, * *, *}$ denote significance at 1,5 and $10 \%$.

Source: World Bank, OECD.

\section{Labour market}

40. Labour markets matter for growth through their impact on both labour utilisation and to a lesser extent labour productivity. A very large body of the literature has examined these effects from a theoretical and empirical point of view. In particular, institutions are usually found to affect the structural unemployment rate, although some of these results sometimes suffer from a lack of robustness (Table 7). 
$\mathrm{ECO} / \mathrm{WKP}(2009) 17$

Table 7: Labour market indicators and performance

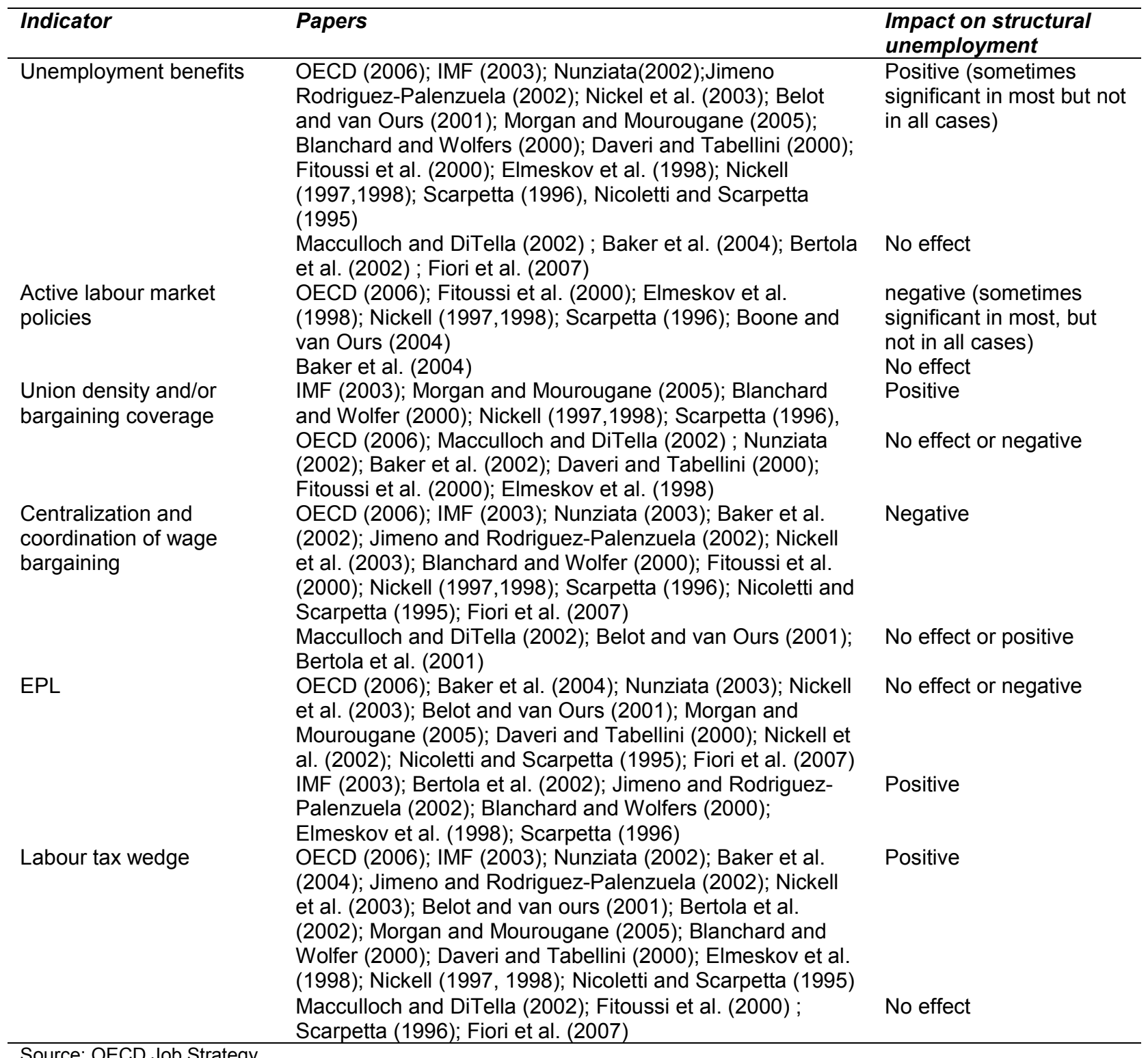

41. Both policy and outcome indicators have been developed to monitor labour markets and are already well covered in the literature and in works published by international organisations (such as Going for Growth published by the OECD). Policy indicators produced at the OECD cover a vast range of labour market institutions ranging from employment protection legislation to data on trade unions. These data are generally available for specific years only and suffer from serious limitations (e.g. EPL measure is a de jure measure and does not reflect effective employment protection). These data are usually only constructed for OECD countries and sometimes for large non-member countries. Other institutional variables such as unemployment benefit generosity or replacement rates are more timely but usually constructed for certain household or worker types. By contrast, a lot of detailed information is available for OECD countries and on a long time span on active labour markets policies and labour taxes. Marginal effective tax rates are also regularly computed for different household types. Data on minimum wages are 
available in the OECD minimum wage database for countries that have a national statutory minimum wage.

42. Other international institutions also publish data on labour market institutions. A large set of institutional variables is collected in the European Commission's LABREF database and the ILO Laborsta database. Qualitative information on the wage system is freely available on the EIRO website. Perceptionbased measures on worker motivations and industrial disputes can also be found in the World competitiveness report which is updated every year. In addition, time-series for selected institutional data such as EPL have been constructed by Allard (2005) and Amable et al. (2007), but the method applied to construct these indicators can be questioned ${ }^{7}$.

43. Outcome indicators include data on employment, unemployment, hours worked and labour force participation. Data are usually fact-based, timely and have a broad country coverage. Efforts have been made over the years to harmonise the data across countries. Moreover, a breakdown by gender, age, skill and sector is also available. The structural (or equilibrium) unemployment rate is a different type of outcome indicator as it is non-observable. It can be estimated using different methodologies, e.g. the OECD Economics Department uses a core price Phillips curve and Kalman filter technique. Indicators of the implicit tax on retirement have also been developed and regularly updated by the OECD.

\section{Product market}

44. Well-functioning product markets affect positively productivity and consumer welfare through various channels (Table 8). Indeed, competition in product markets boosts efficiency in three ways. First, it enhances allocative efficiency. Second, productive efficiency or x-efficiency i.e. the ability of firms to produce output at minimum resource costs can also be increased. Third, competition influences the incentives to innovate and invest - so-called dynamic efficiency. In addition, increased competitive pressures can spur employment growth. At the same time, regulations are important to address market failures stemming for instance from asymmetries of information and externalities. But they also increase firms' compliance costs.

45. A large number of indicators have been developed to measure access to markets and the degree of competition. They are usually based on questionnaires and can be either perception- or fact-based. Although they are usually considered as policy indicators, composite measures sometimes aggregate policy and performance sub-indicators.

46. Among the policy indicators, the World Bank's Doing Business report has attracted a lot of attention because of its broad country coverage and its annual updates. Its objective is to track reforms aimed at simplifying business regulations, strengthening property rights, opening up access to credit and enforcing contracts by measuring their impact on 10 indicator sets. The indicators are then aggregated into an overall ranking comparing ease of doing business across countries. One of the main advantages of this database is that the methodology is transparent, data are comparable across countries, easily replicable and reliability checks are done through the production process. However, the data may not be fully representative of the extent of regulation at the national level as they focus on some specific regions or types of firms. Some data on administrative burdens and labour market institutions have been criticized as being too rough. In addition, some of the data are perception-based. The data also cover only domestically owned, limited liability companies and a limited set of transactions. Moreover, it is assumed that firms have full information on requirements and procedures and the data may underestimate firms' compliance burden.

7. In particular, it can be argued that the additional information used to derive the new indicator can not be easily assigned to EPL sub-indicators. 
47. Another well-known indicator is the Product Market Regulation indicator (PMR) published by the OECD, and its sectoral time-series variants. These are composite indicators summarising information on laws and regulations, as well as the compliance burden born by firms. These indicators are already extensively used in the context of multilateral structural surveillance, in the Going for Growth report or in country Economic Surveys. They have also been extensively used in academic research. They are based on a combination of responses to a questionnaire filled in by country officials and external data sources. The data are thus fact-based, and highly transparent so that it is possible to reproduce the score of the indicator from the results used to derive it. The final outcomes, as well as the underlying data and the methodology are subject to peer review. The weighting procedure has recently been simplified but comparability over time has been ensured through the construction of past data using the same methodology. Moreover, confidence bands are provided, helping the users to assess the reliability of the data. The data are regularly updated every two to three years, with usually improvements in the methodology. Lately non-tariff data in the service sector have been included and complement the tariff data already included in the PMR indicator. The country coverage has been extended over the years and covers now also China and India. Looking forward, the indicator will be enriched by the integration of the indicator of sectoral regulator independence which is found to be closely related to investment in infrastructure (Sutherland et al., forthcoming).

48. The Business Competitiveness Index (BCI) produced by the World Economic Forum is a composite indicator constructed using a combination of survey and hard indicators, including a measure of intellectual property protection and the stringency of environmental regulation. Their focus is on capturing factors that matter for competitiveness at the micro-economic level. The construction process is fully transparent. However, the selection of the different indicators is nonetheless not straightforward and some may be strongly inter-correlated (e.g. intellectual property protection and property rights). Lastly the weights are determined using factor analysis at a lower level of aggregation and regression on GDP per capita at a higher level of aggregation. It is unclear whether the ranking from the BCI is robust to an alternative weighting choice. Finally, there is no information on measurement errors.

49. Overall, past analysis points to a strong correlation between these various indicators for the OECD countries. The correlation between the ease of doing business and the OECD product market regulation indicator is 0.7 .

50. A new indicator is the questionnaire-based measure of whether a sector is subject to incentive price regulation, generally in the form of a price $\mathrm{cap}^{8}$, constructed by the OECD. The indicator is available for all OECD countries except Poland and Greece over the period end 2007- early 2008. The sectoral coverage varies across countries. There is no plan to update the questionnaire so far. The methodology is transparent and the data have been subject to peer review. One main limitation of this indicator is that it does not account for quality changes. There is, however, evidence that this indicator has a positive impact on investment in infrastructure in the presence of an independent regulator (Sutherland et al., forthcoming). Indicators summarising the main features of the regulatory institutions have been constructed in Hoj (2007a). The indicators cover both general and sector-specific competition polices.

8. The regulator specifies a price basket that can increase in line with an exogenous measure of input costs minus measures of efficiency gains. 
ECO/WKP(2009)17

Table 8: Product market indicators and economic performance

\begin{tabular}{|c|c|}
\hline & Results \\
\hline $\begin{array}{l}\text { Nicoletti et al. (2001), } \\
\text { Blanchard and Giavazzi } \\
\text { (2003), Baissanini and } \\
\text { Duval, Griffith et al. (2007) }\end{array}$ & $\begin{array}{l}\text { Anticompetitive product market regulations have significant negative } \\
\text { effects on employment rates. }\end{array}$ \\
\hline $\begin{array}{l}\text { OECD (2003a), Aghion } \\
\text { and Griffith (2005), } \\
\text { Conway et al. (2006), } \\
\text { Arnold et al. (2008), } \\
\text { Nicoletti and Scarpetta } \\
\text { (2005), Scarpetta and } \\
\text { Tressel (2002), Fiori et al. } \\
(2007)\end{array}$ & $\begin{array}{l}\text { Anti-competitive product market regulations are negatively associated } \\
\text { with productivity performance. }\end{array}$ \\
\hline Bayoumi et al (2004) & $\begin{array}{l}\text { Greater competition produces large effects on macroeconomic } \\
\text { performance, as measured by standard indicators. It may also improve } \\
\text { macroeconomic management by increasing the responsiveness of } \\
\text { wages and prices to market conditions. Finally, greater competition can } \\
\text { generate positive spillovers to the rest of the world through its impact on } \\
\text { the terms-of-trade. }\end{array}$ \\
\hline Bassaini and Ernst (2002) & Positive impact of deregulation on R\&D activity. \\
\hline $\begin{array}{l}\text { Scarpetta and Tressel } \\
(2002)\end{array}$ & $\begin{array}{l}\text { Strict regulation hinders the adoption of exiting technologies, possibly by } \\
\text { reducing competitive pressures, technology spillovers, or the entry of } \\
\text { new high-tech firms. }\end{array}$ \\
\hline Bartelman et al. (2003) & Deregulation has a positive impact on the expansion of successful firms. \\
\hline
\end{tabular}

51. A large number of outcome indicators (e.g. firm creation and destruction etc...) are also available but most of the time at a national or sectoral level, and only updated infrequently. Indices of concentration (such as the Herfindal index) are sometimes computed, but not on a regular basis or for a sufficient number of countries. Mark-ups have also been developed in OECD studies and elsewhere (Hoj et al, 2007b).

\section{Infrastructure}

52. The impact of infrastructure on output (and output growth) is difficult to pin down and the direction of causality hard to determine empirically (Table 9). However, there is some empirical evidence that investment has positive effects that go beyond the impact to be expected from a larger capital stock (Sutherland et al., forthcoming). In particular, infrastructure investment appears to have on average a stronger long-term effect on growth at lower levels of provision, though the effect is different between developing and developed countries.

53. Data on infrastructure available over a relatively long time period and comparable across countries are scarce. Capital stock data published by national statistical offices lack harmonisation. They can usually be complemented by physical measures of infrastructure provision, but the latter can not be easily aggregated. Moreover these measures fail to capture the quality of infrastructure.

54. A composite indicator measuring how countries exploit the potential benefits of Public and Private Partnerships (PPPs) have recently been developed by the OECD. The data are available for 19 countries, though not for the United Kingdom which has made extensive use of PPPs in the past. Data are questionnaire- based. No update is, however, currently planned. 
Table 9: Infrastructure and economic performance

\begin{tabular}{|c|c|}
\hline & Results \\
\hline $\begin{array}{l}\text { Ford and Poret } \\
\text { (1991) }\end{array}$ & $\begin{array}{l}\text { Infrastucture can have growth enhancing effect but the relation is weak } \\
\text { and unstable }\end{array}$ \\
\hline Bonaglia et al. (2000) & $\begin{array}{l}\text { Infrastructure makes a positive contribution to productivity in some } \\
\text { Italian regions }\end{array}$ \\
\hline Kozerec et al. (2001) & $\begin{array}{l}\text { Strong positive contribution of telecom and electricity, gas and water on } \\
\text { productivity in the United States and Europe }\end{array}$ \\
\hline $\begin{array}{l}\text { Sutherland et al. } \\
\text { (forthcoming) }\end{array}$ & $\begin{array}{l}\text { Evidence that infrastructure has a positive effect that goes beyong the } \\
\text { expected impact from capital stock. }\end{array}$ \\
\hline $\begin{array}{l}\text { Hurlein (2006), } \\
\text { Bougheas et al. } \\
\text { (2000), Sutherland et } \\
\text { al. (forthcoming) }\end{array}$ & Evidence that the link between infrastructure and growth is non-linear \\
\hline
\end{tabular}

\section{International trade}

55. The last three decades have witnessed rapid economic integration. This has spurred an economic on trade and its effects on growth and living standards, both from a theoretical and an empirical point of view.

56. From a theoretical point of view, there are different channels through which trade can stimulate growth and improve living standards. First, according to the theory of comparative advantages, trade based on specialisation increases domestic output due to higher productivity. Second, trade is a means to increase worldwide competition in production, and to enhance efficiency. Third, trade guarantees a greater choice of products. Fourth, it expands potential markets and permits domestic firms to take advantage of economies of scale. Fifth, trade allows the diffusion of knowledge and technological innovation.

57. From an empirical point of view there is a large literature showing that economies that are more open to international trade have higher rates of growth, as a result of higher investment, human capital accumulation, higher technology diffusion and sustained gains in factor productivity ${ }^{9}$.

58. These empirical works, however, differ in the approach of measuring trade openness. In particular, it is possible to classify the empirical research investigating the relation between trade and growth in two branches: those that use policy indicators as measures of trade openness, and those that use outcome indicators (in terms of trade intensity).

59. Trade policy indicators describe the institutional features of a country's attitude toward the rest of the world. The most common policy indicators are tariff barriers (or the effective tariff). However, there are many different policy instruments, i.e. non-tariff barriers (such as quotas, exemptions, special permits, and discriminatory practices) that can affect trade and which can be considered a better proxy for trade openness, especially in developed countries. ${ }^{10}$ Thus, other indicators such as the one provided by the

9. In particular, Wacziarg (2001) considers six channels trough which trade affects growth: (1) macroeconomic policy quality, (2) government size, (3) price distortions from the existence of black market premium, (4) investment share of GDP, (5) technology, and (6) foreign direct investment. His results show that the most important channel is investment, accounting for 63 percent of trade's total effect on growth, while the technology channel and the stabilizing channel account for the rest of the effect. For other empirical results see Lewer and Van den Berg (2003) which presents a critical survey of the literature on this topic.

10. Existing standards or regulation regarding safety or environmental issues are another form of non-tariff barriers. These barriers may be more stringent for developed countries than more traditional forms of non-barriers. 
Heritage foundation, Sachs and Warner (1995) and Wacziarg (2001) have used both tariff and non-tariff barriers to construct an indicator for trade openness. The main advantage of these indicators is the (almost) absent problem of endogeneity with respect to growth. In contrast, the main limitation is their limited availability, and the fact that they usually reflect the legal framework in which agents operate, but not the effective degree of protection they face.

60. A policy indicator of trade openness has been constructed by the Heritage Foundation. The indicator is transparent in the way it is constructed and data are available for a very broad set of countries (161) from 1995 to 2007 , based on well documented sources ${ }^{11}$. The indicator is based on both trade and non-tariff barriers. While this is an advantage to other indicators based exclusively on tariff barriers, it has the main disadvantage that non-tariffs barriers are difficult to construct and often require subjective judgments. However, the indicator is positively correlated with outcome indicator such as GDP's share of total exports and imports and it shows a strong and positive correlation with GDP per capita ${ }^{12}$.This suggests that the indicator is reliable (measure what it pretends) and matters for living standards.

61. An alternative would be to restrict the construction of the indicator to tariff barriers. The OECD collects tariff data for most of its member countries. However, the outcome does not seem to be well correlated with openness, suggesting that abstracting from non-tariff barriers would lead to a serious bias and lower the usefulness of the data.

62. Another policy indicator is the FDI restrictiveness index constructed by Golub (2003) and updated in Koyama and Golub (2006). The indicator is available for OECD economies and 13 non OECD economies. It covers three categories of restrictions: limitations on foreign ownership, screening or notification procedures and management or operational restrictions.

63. Outcome indicators describe the volumes and values of existing trade. The outcome indicator that has been mostly used to investigate the relation between trade and growth are export growth (see Table 10) and the share of total exports and imports to GDP. Other indicators of the same type are the structureadjusted trade intensity (which is the ratio of real imports plus real exports to real GDP, corrected for transportation costs, country size and country income) and the ratio of imports to aggregate consumption. These indicators are all fact-based, and easy to construct. Moreover, many international organisations collect data on exports and imports (differentiated by structure, destination and origin) and these indicators are easy to compute. The main drawback of this type of indicator is the endogeneity problem with respect to growth (Frankel and Romer, 1995).

11. The authors used the following sources to determine scores for trade policy, in order of priority: World Bank, World Development Indicators 2007 and Data on Trade and Import Barriers: Trends in Average Tariff for Developing and Industrial Countries 1981-2005; World Trade Organization, Trade Policy Reviews, 1995-2007; Office of the U.S. Trade Representative, 2007 National Trade Estimate Report on Foreign Trade Barriers; World Bank, Doing Business 2008; U.S. Department of Commerce, Country Commercial Guide, 2004-2007; Economist Intelligence Unit, Country Report, Country Profile, and Country Commerce, 2004-2007; and official government publications of each country.

12. The indicator has astrong and positive relation both overtime and cross country with GDP per capita. It is important to stress, however, that cross country variation is the most important source of variability. 
Table 10: Trade growth and economic performance: effects of real export growth on real GDP growth

\begin{tabular}{ll}
\hline Average coefficient value & 0.220 \\
Median coefficient value & 0.189 \\
Average t-Statistic & $3.460 * *$ \\
Maximum coefficient value & 1.851 \\
Minimum coefficient calue & -1.433 \\
Average standard error & 0.021 \\
Average 95\% eonfidence interval & \pm 0.042 \\
Average Kurtosis distribution & 11.502 \\
Average skewness & -0.134 \\
Notes: **Significant at the 95\% level. Based on 196 regressions. & \\
Source: Levewr and Van den Berg (2003) &
\end{tabular}

\section{Financial markets}

64. Financial markets influence capital accumulation and productivity growth through their intermediation role. They foster the efficient allocation of capital, facilitate international capital flows and allow the pooling of risks and spreading of information about investment opportunities.

65. From an empirical point of view there is a large literature finding that economies with more developed financial markets have higher rates of growth. In particular, according to cross-country comparisons, individual country studies as well as industry and firm level analyses, a positive link exists between the sophistication, the deepness and the well functioning of the financial system and economic growth (see Table 11).

66. To assess the effect of financial markets on economic growth two sets of indicators have been used: policy indicators and outcome indicators.

67. Financial policy indicators try to measure aspects of domestic and financial markets mostly related to the regulatory stance, both as regards stability, competition and liberalisation. The main advantage of these indicators is the (almost) absent problem of endogeneity with respect to growth. Moreover, while until the last decade data were not easily available, today many organisations have undertaken (IMF, World Bank) or in the process of undertaking (OECD) projects to construct databases on financial policy indicators. Similarly, the importance of financial liberalisation for living standards and economic growth has encouraged independent organisations (such as the Heritage Foundation) to build their own policy indicators.

68. Outcome indicators describe the deepness, the efficiency, the concentration of domestic financial markets, and the degree of financial liberalisation. The Fraser Institute has constructed an index that measures the freedom to exchange with foreigners called Economic Freedom of the World. With regard to the domestic financial market, Beck et al. (2007) construct perhaps the most comprehensive dataset of indicators that measure the size, activity, and efficiency of financial intermediaries and markets (some of these indicators are, for example, financial market capitalisation, bank concentration, net interest rate margin, credit and bank deposit, and other measures of financial deepness). With regards to international finance, outcome indicators often follow the same methodology of trade outcome indicators. Examples of these indicators are: the financial liberation indicator (overall stock of external liabilities and assets to GDP) and the financial freedom indicator (the share of portfolio equity and FDI to GDP, and the share of equity liabilities in total liabilities). ${ }^{13}$ Data on the variables used to calculate the indicators are from official

13. See Lane and Milessi-Ferretti (2007). 
sources (IMF, World Bank) and are available for a large time span and very broad set of countries. Moreover, the indicators seem to matter for living standards. In fact, they are positively and significantly associated with GDP, both across countries and over time (Figure 7).

69. While all these indicators are easy to measure and can be used to assess the implication of the financial structure and liberalisation on growth, their main drawback is the presence of endogeneity problems with respect to growth. Thus, their use to assess the impact of financial markets on growth has to be considered jointly with the use of policy indicators (as instruments).

\section{Figure 7: Correlation between selected indicators of financial developments and GDP per capita}

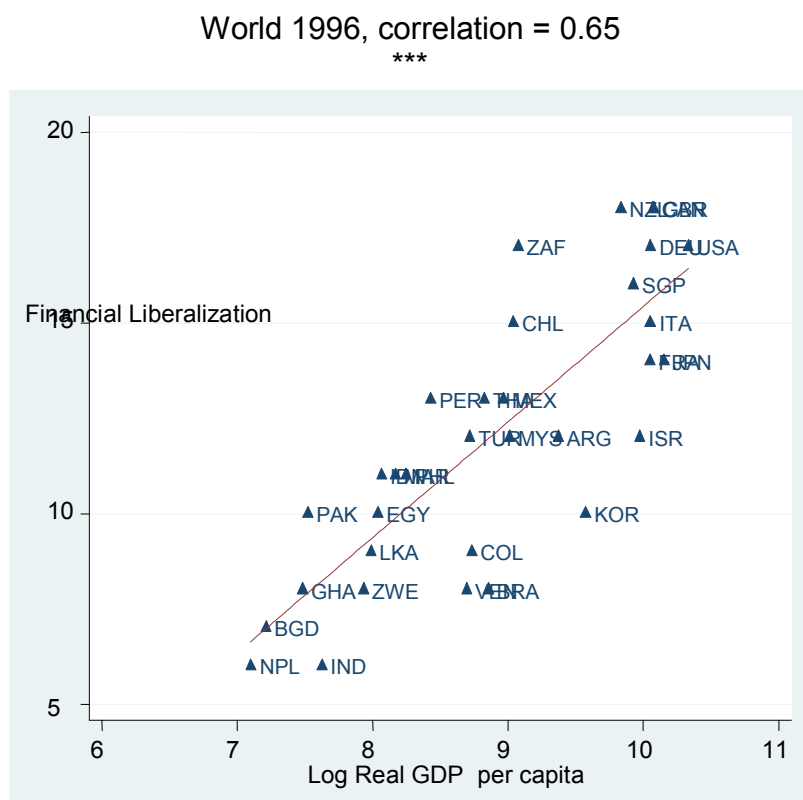

World 2005, correlation $=-0.21^{* \star *}$

OECD 2005 correlation $=-0.32^{*}$
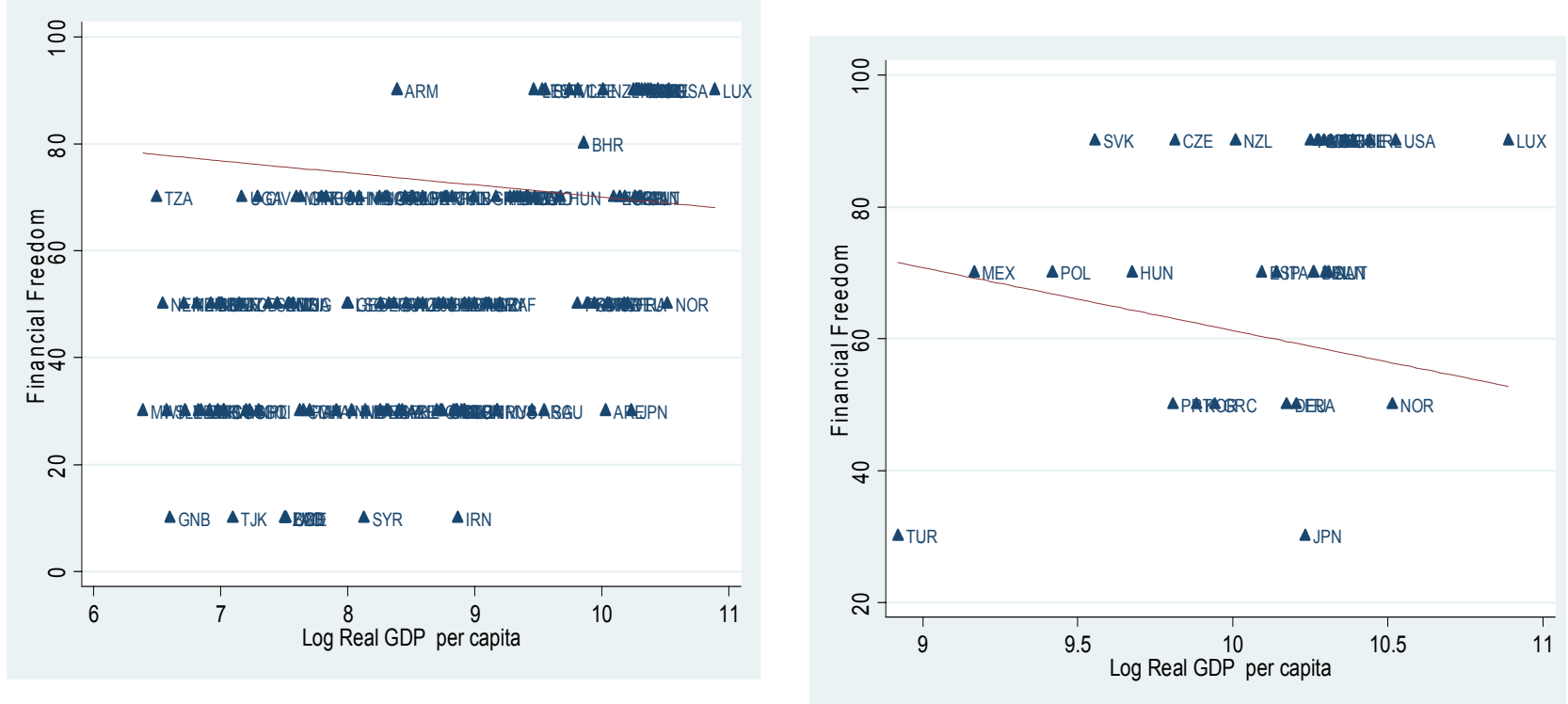

Note: ${ }^{* * *}, * *,{ }^{*}$ denote significance at 1,5 and $10 \%$.

Source: World Bank, IMF. 
ECO/WKP(2009)17

Table 11: Financial markets and economic growth

\begin{tabular}{l}
\hline De Serre et al. (2007) \\
Atje and Jovanovic (1993) and \\
Levine and Zervos (1998) \\
Levine (1998, 1999) and Levine et al. \\
(2000)
\end{tabular}

Aghion et al. (2005)

Indicator used or methodology and results

A set of indicators of banking and regulation created from the World Bank

Regulation and Supervision database for 25 OECD countries.

Regulation which is more conducive to competitive and efficient financial

markets have a positive impact on output and productivity.

Stock market trading as a share of GDP

Positive correlation between stock market trading and growth.

Use GMM and a country's legal origin as an instrument for financial

development.

Establish a causal link between finance and growth.

Same technique as in Levine et al. (2000)

Financial development influences the speed of growth convergence rather than the steady state.

Benhabib and Spiegel (2000)

Indicators of financial development are correlated to both TFP growth and to the accumulation of physical and human capital. But the indicators that are strongly correlated with total factor productivity growth differ from those boosting investment.

Rioja and Valev (2004a, 2004b) The impact of financial development on growth may vary with the level of financial development and of income.

Loayza and Rancière (2005)

Evidence that a positive long-run relationship between financial intermediation and output growth can co-exist with a negative short-run relationship.

Use a wide variety of measures of international financial integration and of equity market liberalisation. Introduce an interaction variable : GDP*capital account liberalisation.

International financial integration does not in general accelerate economic growth after controlling for financial and institutional characteristics. But interaction variables are found to be significant.

Rajan and Zingales (1998)

Estimate measures of the financial dependence of industries (i.e. a reliance on financing from outside) and interact this measure with measure of financial development.

There is a significant and sizeable causal effect from the state of financial markets to economic growth.

Demirguc-Kunt and Maksimovic In countries with better financial development, relatively more firms grow faster than predicted by internal accounting data.

(1998)

Financial development exerts a positive growth effect on industries that are technologically more dependent on small firms.

Becker and Sivadasan (2006) Financial development may mitigate financial constraints of firms and enhance investment.

Source: OECD Secretariat

\section{Reform and composite indicators}

70. Measuring progress in structural reforms is crucial to formulate policy recommendations. Information on individual reforms is currently collected by the European Commission in its MICREF database for EU countries. These data often come from other international organisations or one-off studies. Indicators of reform intensity have been constructed as the average of labour (or product) market institutions for OECD countries (Hoj et al., 2006). There has been some interesting attempts to construct summary measures of reform progress by aggregating variables in different areas (Lora and Panizza, 2002; Eicher and Röhn, 2007). These indicators suffer from the drawbacks associated with composite indicators, in particular the difficulty of interpreting them and the arbitrariness of the chosen weights. It remains also to be seen whether these indicators could be updated at a sufficient frequency to allow a regular monitoring of progress.

71. Among the composite indicators that cover a large number of areas, it is worth mentioning the Global Competitiveness index from the World Economic Forum which takes into account both macroeconomic and microeconomic foundations of competitiveness. Its scope is very large in terms of 
areas covered and country coverage. The indicator is a weighted average of indicators gathered in 12 pillars ${ }^{14}$. Weights of the different pillars depend on the country's level of development, but robustness checks suggest that the index is not sensitive to the weights. This indicator is regularly updated. However, regular changes in the methodology (in terms of data source or composition of the index ${ }^{15}$ ) cast doubts on its comparability over time.

\section{Conclusion}

72. The analysis undertaken in this paper has identified a number of areas which matter for living standards, but are currently not well captured by existing indicators. Although numerous indicators in these areas are currently available, these do not always meet the standards required in the context of international benchmarking exercise. Governance is clearly a domain that matters for living standards, but is currently absent in the framework. However, existing good governance measures are mostly perception based and cannot be credibly used for policy recommendations. Further work will be required to develop fact-based indicators in several dimensions of governance. It will be particularly helpful to construct an indicator of property rights and continue work on developing indicators of government management systems.

73. Depending on their use, the question of the regular update of these indicators can also be vital. Most of the structural indicators are, however usually developed in the context of a one-off study and/or not updated at regular intervals. This prevents their use in empirical work where time series are needed or in a surveillance process where reform progress is closely monitored.

14. Institutions, macroeconomy, health, primary education, higher education and training, goods market efficiency, labour market efficiency, financial market sophistication, technological readiness, market size, business sophistication and innovation.

15. For instance the exchange rate has been recently removed from the index. 


\section{REFERENCES}

\section{General}

Loayza, N. and R. Soto (2003), "On the Measurement of Market-Oriented Reforms”, World Bank research paper, December.

Woelf, A. (forthcoming), "Product Market Regulation in OECD Countries 1998-2007: Update and extension of the OECD PMR Indicator", OECD Economics Department Working Paper.

\section{Governance}

Acemoglu, D., S. Johnson, and J. Robinson 2001. "The Colonial Origins of Comparative

Development: An Empirical Investigation.” American Economic Review 91(5): 1369-1401.

Acemoglu, D., S. Johnson and J. Robinson (2005), "Institutions as the Fundamental Causes of Long-Run Growth", in Handbook of Economic Growth, eds P. Aghion and S. Durlauf, Elsevier Book, Oxford.

Alfonso, A. and Furceri, D (2008). "Government Size, Composition, Volatility and Economic growth," European Central Bank Working Paper Series 849.

Arndt, C. and C. Oman (2006), "Use and Abuse of Governance Indicators", Development Center Studies.

Arnold, J. (2008), "Do Tax Structures Affect Aggregate Economic Growth? Empirical evidence from a panel of OECD countries", OECD Economics Department Working Paper, No. 643.

Barro, R. and X. Sala-i-Martin (1991), "Convergence Across States and Regions," Papers 629, Yale Economic Growth Center.

Boulhol, H. and A. de Serres (2008), "Have developed countries escaped the curse of distance?", OECD Economics Department Working Paper, No. 610.

Easterly, W. (2005), "National Policies and Economic Growth: A Reappraisal”, in the Handbook of Economic Growth, edited by P. Aghion and S. Durlauf.

Folster, S. and Henrekson, M. (2001). "Growth Effects of Government Expenditure and Taxation in Rich Countries," European Economic Review, Elsevier, vol. 45(8), pages 1501-1520.

Furceri, D. (2006), "Beta and Sigma-convergence: A Mathematical Relation of Causality", Economics Letters, 89 (2), 212-215.

Glaeser, E., F. Lopez-de-Silanes and A. Schleifer (2004), “Do Institutions Cause Growth?”, Journal of Economic Growth, 9, 271-303.

Globerman, S. and D. Shapiro (2002), "Global Foreign Direct Investment Flows: The Role of Governance Infrastructure", World Development, Vol. 30.

Gradstein, M. (2008), "Institutional Traps and Economic Growth", International Economic Review, Vol. 49, No. 3, August 2008. 
Jaumotte, F. and N. Pain (2005), "Innovation in the Business Sector", OECD Economics Department Working Paper, No. 459.

Johansson, A., C. Heady, J. Arnold, B. and L. Vartia (2008), “Taxation and Economic Growth”, OECD Economics Department Working Paper, No. 620.

Kaufmann, D. and A. Kraay (2002), Growth without Governance, Economia, 3, pp. 169-229.

Kaufmann, D., A. Kraay and M. Mastruzzi. ( 2008), "Governance Matters VII:Aggregate and Individual Governance Indicators 1996-2007”, World Bank Policy Research Working Paper 4654.

Kaufmann, D. (2008), "Corruption, Governance and Security: Challenges for the Rich Countries and the World”, World Bank Governance Matters, Chapter 2.1.

Kraay, A. and V. Nehru (2004), "When is External Debt Sustainable?”, World Bank Policy Research Working Paper No. 3200.

Knack, S. and P. Keefer. 1995. "Institution and Economic Performance: Cross-Country Tests Using Alternative Institutional Measures.", Economics and Politics, 7: 207-227.

Lambsdorff, J. (1999), "Corruption in Empirical Research - A Review”, Transparency International Working Paper.

Marshall, M. and B. Cole (2008), Global Report on Conflict, Governance and State Fragility 2008, Foreign Policy Bulletin: The Documentary Record of United States Foreign Policy (2008), 18:3-21 Cambridge University Press

Mauro, P. (1995), "Corruption and Growth", Quarterly Journal of Economics, CX, 681-712.

Milesi-Ferretti, G. M., R. Perotti and M. Rostagno (2002), "Electoral Systems and Public Spending", The Quarterly Journal of Economics, May.

Nicoletti, G. and F. Pryor (2006), "Subjective and Objective Measures of Governmental regulations in OECD nations", Journal of Economic Behaviour and Organization, Vol 59 (2006) 433-449.

North, D.C. (1990), Institutions, Institutional Change and Economic Performance, Cambridge University Press, Cambridge, United Kingdom.

North, D.C. (2005), Understanding the Process of Economic Change, Princeton University Press, New Jersey.

OECD (2005), "Handbook on Constructing Composite Indicators: Methodology and User Guide", OECD Statistics Working Papers 2005/3.

Persson, T. and G. Tabellini (2003), The Economic Effects of Constitutions. Cambridge, MA: MIT Press.

Persson, T. and G. Tabellini (2004), "Constitutional Rules and Economic Policy Outcomes", American Economic Review, 94:25-46.

Przeworski, A., M.E. Alvarez, J.A. Cheibub and F. Limongi (2000), Democracy and Development: Political Institutions and Well-Being in the World, 1950-1990, Cambridge University Press, Cambridge, United Kingdom.

Rodrick D., A. Subramanian and F. Trebbi (2004), "Institution Rule: The primary of institutions over Geography and Integration in Economic Development", Journal of economic growth 9, 131-165.

Sala-i-Martin, Xavier X (1996),"The Classical Approach to Convergence Analysis," Economic Journal, vol. 106(437), 1019-36.

Welsh H. (2008), “The Welfare Costs of Corruption”, Applied Economics, 2008, 40, 1839-1849. 


\section{Society}

Barro, R.J (2001). "Human Capital and Growth," American Economic Review, vol. 91(2), 12-17.

Barro, R. (1996). "Health and economic growth" Mimeo. Cambridge, MA: Harvard University.

Barro, R. (1997), Determinants of Economic Growth: a Cross-Country Study, MIT Press, Cambridge.

Barro, R., and Lee, J. (1994), "Sources of economic growth". Carnegie-Rochester Conference Series on Public Policy 40, 1-46.

Barro, R., and Sala-I-Martin, X. (1995). Economic growth. New York: McGraw-Hill.

Bhargava, A., Jamison, D., Lau, L., and Murray, C. (2001), "Modeling the effects of health on economic growth". Journal of Health Economics, 20(3), 423-440.

Berger, M. and J. Messer (2002), "Public Financing of Health Expenditure, Insurance, and Health Outcomes", Applied Economics, Vol. 34, No. 17, pp. 2105-2113.

Bloom, D.E. and D.,Canning,(2005) "Health and Economic Growth: Reconciling the Micro and Macro Evidence," mimeo, Harvard School of Public Health, 2005.

Bloom, D. E., Canning, D., and Malaney, P. N. (2000). Demographic change and economic growth in Asia. Population and Development Review, 26, 257-290.

Bloom, D, E., Canning, D. and Sevilla,J. (2004) "The Effect of Health on Economic Growth: A production Function Approach," World Development XXXII, 1-13.

Bloom, D. E., and Williamson, J. G. (1998). "Demographic transitions and economic miracles in emerging Asia". World Bank Economic Review, 12(3), 419-455.

Caselli, F., Esquivel, G., and Lefort, F. (1996). Reopening the convergence debate: a new look at cross country growth empirics. Journal of Economic Growth, 1,363-389.

Cohen, D. and M. Soto (2001). "Growth and Human Capital: Good Data, Good Results", CEPR Discussion Paper no. 3025.

Coulombe, S., J. F. Tremblay and S. Marchand (2004), "Literacy Scores, Human Capital and Growth across Fourteen OECD Countries." Statistics Canada.

de la Fuente, A. and R. Doménech ( 2006), "Human Capital in Growth Regressions: How much Difference does Data Quality Make?", Journal of the European Economic Association 4(1), pp. 1-36.

Dormont, B., J. Oliveira Martins, F. Pelgrin and M. Suhrcke (2008), "Health Expanditure, longevity and Growth", prepared for the IX Annual Conference of the Fondazione Rodolfo de Benedetti on Health, Longevity and Productivity, held at Limone sul Garda May 2007.

Finlay, J. (2007), "The role of health in economic development”, PGDA Working Papers

Jamison, Dean, T., Lawrence J. Lau, and Jia Wang (2005), "Health's Contribution to Economic Growth in an Environment of Partially Endogenous Technological Progress" in Guillem Lopez- Casasnovas, Berta Rivera, and Luis Currais, eds., Health and Economic Growth, (Cambridge, MA: MIT Press, 2005).

Gallup, J., and Sachs, J. (2000), “The economic burden of malaria”. Working Paper No. 52, Center for International Development, Harvard University, Cambridge,MA.

Hanushek, E. and D. Kimko (2000). "Schooling, Labor-Force Quality and the Growth of Nations." American Economic Review 90(5), pp. 1184-208.

Harmon, C., I. Walker and N. Westergaard-Nielsen (2001), "Introduction," in C. Harmon, I. Walker and N. Westergaard-Nielsen, editors, Education and earnings in Europe: A cross-country analysis of the returns to education, Edward Elgar, Cheltenham, pp. 1-37. 
Joumard, I., André, C., Nicq, C., and O. Chatal, (2008). "Health Status Determinants: Lifestyle, Environment, Health Care Resources and Efficiency," OECD Economics Department Working Paper No. 627.

Krueger, A. \& Lindahl, M. (2001), 'Education for Growth: Why and for Whom?', Journal of Economic Literature 39, 1101-1136.

Mankiw, G., D. Romer and D. Weil (1992). "A Contribution to the Empirics of Economic Growth." Quartely Journal of Economics, pp. 407-37.

Oliveira Martins, J., R. Boarini, H. Strauss, C. de la Maisonneuve and C. Saadi (2007), "The Policy Determinants of Investment in Tertiary Education, OECD Economics Department Working Paper No. 576.

Oulton, N. (1997), 'Total Factor Productivity Growth and the Role of Externalities', National Institute Economic Review (162), 99-111.

Price, R., E. Erlandsen and I. Joumard (2008), "Spending Efficiency in Health Care and Economic Growth", Osaka economic Papers, Vol. 58, No. 2, September.Self, S. and R. Grabowski (2003), "How Effective is Public Health Expenditure in Improving Overall Health? A Cross-country Analysis", Applied Economics, Vol. 35, pp. 835-845.

Sachs, J. and A. Warner. (1997). "Sources of slow growth in African economies". Journal of African Economics, 6, 335-337.

Soares, R.R. (2007), "Health and the Evolution of Welfare across Brazilian Municipalities", Journal of Development Economics, Vol. 84, pp. 590-608.

Suhrcke, M. and D. Urban (2006), “Are Caridiovascular diseases bad fir economic growth?”, CEifo working paper 1845 .

Topel, R. (1999), The Labour Market and Economic Growth, in O. Ashenfelter \& D. Card, eds, 'The Handbook of Labour Economics', North Holland, Amsterdam, Ch. 44.

\section{Labour markets}

Allard, G. (2005), "Measuring Job Security over time: In search of a historical Indicator"

Amable, B., L. Demmou and D. Gatti (2007), "Employment Performance and Institutions: New Answers to Old Question”, IZA Discussion Paper 2731.

Baker, D., A. Glyn, D. Howell and J. Schmitt (2004), "Labour Market Institutions and Unemployment: a Critical assessment of cross-country evidence", forthcoming in D. Howell (ed.), Fighting Unemployment: the limits of free market orthodoxy, Oxford University Press, Oxford.

Belot, M. and J. Van Ours (2001), "Unemployment and Labor Market Institutions: An Empirical Analysis", Journal of the Japanese and International Economy, Vol. 15, No. 4.

Blanchard, O. and Wolfers, J. (2000), "The role of shocks and institutions in the rise of European Unemployment: The aggregate evidence", The Economic Journal, Vol. 110, pp. C1-C33.

Bertola G., F. Blau and L. Kahn (2002), "Labor Market Institutions and Demographic Employment Patterns", NBER Working Paper No. 9043, July.

Boone, J. and J. Van Ours (2004), "Effective Active Labor Market Policies", IZA Discussion Paper, No. 1335 , November.

Daveri, F. and G. Tabellini (2000), "Unemployment, Growth and Taxation in Industrial Countries", Economic Policy, Vol. 0, Issue 30, April. 
Fitoussi, J.P., D. Djestaz, E. S. Phelps, G. Zoega (2000), "Roots of the Recent Recoveries:Labor Reforms or Private Sector Forces?", Brookings Papers on Economic Activity, 1:2000, p 237-256.

Elmeskov, J., Martin, J.P. and Scarpetta, S. (1998) 'Key Lessons for labour Market Reforms: Evidence from OECD Countries' Experiences', Swedish Economic Policy Review, Vol. 5, pp. 205-252.

International Monetary Fund (2003), "Unemployment and Labor Market Institutions: Why Reforms Pay Off", World Economic Outlook, Chapter IV, April.

Jimeno, J. F. and D. Rodriguez-Palenzuela (2002). "Youth Unemployment in the OECD : Demographic Shifts, Labour Market Institutions, and Macroeconomic Shocks", European Central Bank Working paper 155. OECD (2006), Restated Job Strategy.

Macculloch, R. and R. Di Tella (2002), "The Consequences of Labor Market Flexibility: Panel Evidence Based on Survey Data", Harvard NOM Research Paper No. 03-47.

Morgan, J. and A. Mourougane (2005), "Structural unemployment and labour market institutions in Europe", Scottish Journal of Political Economy, Vol. 52, No 1, February.

Nickell, S., L. Nunziata and W. Ochel (2003), "Unemployment in the OECD since the 1960s: What do we know?", mimeo, Bank of England.

Nickell, S. J. (1997), 'Unemployment and labor market rigidities: Europe versus North America', Journal of Economic Perspectives, Vol. 11, No. 3, pp. 55-74.

Nickell, S. (1998), "Unemployment: Questions and Some Answers", The Economic Journal, Vol. 108, Issue 448, May.

Nunziata, L. (2002), "Unemployment, Labour Market Institutions and Shocks”, Nuffield College Working Papers in Economics, 2002-W16.

Scarpetta, S. (1996), 'Assessing the Role of Labour Market Policies and Institutional Settings on Unemployment: a Cross Country Study’, OECD Economic Studies, No. 26 1996/1, pp. 43-97.

\section{Product markets}

Arnold, J., G. Nicoletti and S. Scarpetta (2008), "Regulation, Allocative Efficiency and Productivity in OECD Countries: Industry and Firm-Level Evidence", OECD Economics Department Working Paper, No. 616.

Aghion, P. and Griffith (2005), Competition and Growth Reconciling Theory and Evidence, MIT Press.

Baissanini, A. and R. Duval (2006) , "Employment Patterns in OECD Countries: Reassessing the Role of Policies and Institutions", OECD Economics Department Working Paper, No 486, June.

Bassanini, A. and E. Ernst (2002), "Labour Market Institution, Product Market Regulation and Innovation: Cross-countries Evidence", OECD Economics Department Working Paper, No. 316, January.

Blanchard, O. and F. Giavazzi (2003), "Macroeconomic Effects of Regulation and Deregulation on Goods and Labour Markets", Quarterly Journal of Economics, Vol. 118, No. 3, pp. 879-907.

Bayoumi, T., D. Laxton and P. Pesenti (2004), "Benefits and spillovers of greater competition in Europe: a macroeconomic assessment”, NBER Working paper No. 10416, April, Cambridge.

Bartelsman, E., S. Scarpetta and F. Schivardi (2003), "Comparative Analysis of Firm Demographics and Survival Micro-level Evidence for the OECD Countries", OECD Economic Department Working Paper, No. 348.

Conway, P., D. De Rosa, G. Nicoletti and F. Steiner. (2006), "Regulation, Competition and Productivity Convergence", OECD Economics Department Working Paper No. 509, September. 
Griffith, R., R. Harrison and G. Macartney (2007), "Product Market Reforms, Labour Market Institutions and Unemployment", Economic Journal, 117, March, C142-C166.

Hoj J. (2007a), “The Competition Law and policy Indicator, OECD Economics department Working Paper No. 568.

Hoj J., M. Jimenez, M. Maher, G. Nicoletti and M. Wise (2007b), "Product Market competition in the OECD Countries: Taking Stock and Moving Forward", OECD Economics department Working Paper No. 575.

OECD (2003a), "What Drives Productivity Growth at the Industry Level?", in The Source of Economic Growth in OECD Countries, Chapter 3, Paris.

Nicoletti, G., A. Bassanini, E. Ernst, S. Jean, P. Santiago and P. Swaim. (2001), "Product and Labour Market Interaction in OECD Countries", OECD Economics Department Working Paper No. 312, December.

Nicoletti, G. and S. Scarpetta (2003), "Regulation Productivity and Growth: OECD Evidence", OECD Economics Department Working Paper No. 347, January.

Scarpetta, S. and T. Tressel (2002), "Productivity and convergence in a panel of OECD industries: do regulations and institutions matter?", OECD Economics Department working paper No. 342, September.

\section{Infrastructure}

Bougheas, S., P. Demetriades and T. Mamuneas (2000), "Infrastructure, Specialization, and Economic Growth", Canadian Journal of Economics, 33 (2), pp. 506-522.

Ford, R., and P. Poret (1991), "Infrastructure and Private-Sector Productivity", OECD Department of Economics and Statistics Working Paper, No. 91.

Bonaglia, F., E. La Ferrara and M. Marcellino (2000), "Public Capital and Economic Performance: Evidence from Italy", Giornale degli Economisti, 60.

Koszerek, D., K. Havik, K. McMorrow, W. Röger, and F. Schönborn (2007), "An Overview of the EU KLEMS Growth and Productivity Accounts”, European Economy Economic Papers, No. 290.

Hurlin, C. (2006), "Network Effects of the Productivity of Infrastructure in Developing Countries," World Bank Policy Research Working Paper Series No. 3808.

Sutherland D. , S. Araujo, B, Egert and T. Kozluk (forthcoming), "Infrastructure Investment: Links to Growth and the Role of Public Policies", OECD Economics Department working paper.

\section{Financial markets}

Aghion, P., P. Howitt and D. Mayer-Foulkes (2005), "The Effect of Financial Development on Convergence: Theory and Evidence", Quarterly Journal of Economics, Vol. 120.

Atje, R. and B. Jovanovic (1993), "Stock Markets and Development", European Economic Review, Vol. 37.

Beck, T., A. Demirguc-Kunt, L. Laeven, and R. Levine (2004), "Finance, Firm Size, and Growth", NBER Working Paper 10983.

Becker, Bo and J. Sivadasan (2006), "The Effect of Financial Development on the Investment Cash Flow Relationship: Cross-Country Evidence from Europe", European Central Bank Working Paper No. 689.

Benhabib, J. and M.M. Spiegel (2000), "The Role of Financial Development in Growth and Investment", Journal of Economic Growth, Vol. 5.

Demirgüç-Kunt, A. and V. Maksimovic (1998), "Law, Finance and Firm Growth”, Journal of Finance, Vol. 53. 
de Serres, A., S. Kobayakawa, T. Sløk and L. Vartia (2006), "Regulation of Financial Systems and Economic Growth", OECD Economics Department Working Paper No. 506.

Edison, H., M. Klein, L. Ricci and T. Sløk, (2004), "Capital Account Liberalization and Economic Performance: Survey and Synthesis", IMF Staff Paper, Vol. 51.

Edison, H., R. Levine, L. Ricci and T. Sløk, (2002), "International Financial Integration and Economic Growth", Journal of International Money and Finance, Vol. 21.

Levine, R. and S. Zervos (1998), "Stock Markets, Banks and Economic Growth", American Economic Review, Vol. 88 .

Levine, R. (1998), “The Legal Environment, Banks and Long-run Economic Growth”, Journal of Money Credit and Banking, Vol. 30.

Levine, R. (1999), “Law, Finance and Economic Growth”, Journal of Financial Intermediation, Vol. 8.

Levine, R., N. Loayza and T. Beck (2000), "Financial Intermediation and Growth: Causality and Causes", Journal of Monetary Economics, Vol. 46.

Loayza, N. and R. Ranciere (2005), "Financial Development, Financial Fragility and Growth", IMF Working Paper No. WP/05/170.

Rajan, R. G., and L. Zingales, (1998), "Financial Dependence and Growth.", American Economic Review, Vol. 88.

Rioja, F. and N. Valev (2004a), "Finance and the Sources of Growth at Various Stages of Economic Development", Economic Inquiry, Vol. 42.

Rioja, F. and N. Valev (2004b), "Does One Size Fits All? A Re-examination of the Finance and Growth Relationship", Journal of Development Economics, Vol. 74.

\section{International Trade}

Frankel, J. and Romer, D. 1995. "Trade and Growth: An Empirical Investigation," NBER Working Papers 5476.

Golub S. (2003),"Measures of restrictions on inward foreign direct investments for OECD countries", OECD Economics Department Working Paper No.357.

Koyama T. and S. Golub (2006), “OECD's FDI regulatory restrictiveness index: Revisions and extensions too more OECD economies", OECD Economics Department Working Paper No. 525.

Lewer, J. and H. Van den Berg (2003) "How large is international trade's effect on economic growth?", Journal of Economic Surveys, 17 (3), 363-396.

Sachs, J. and Warner, D. 1995. "Economic Reform and the Progress of Global Integration," Harvard Institute of Economic Research Working Papers 1733, Harvard - Institute of Economic Research.

Wacziarg, R. (2001) "Measuring the dynamic gains from trade”, World Bank Policy Research Paper 2001.

\section{Reform and composite indicator}

Eicher, T. and O. Röhm (2007), "Institutional determinants of economic Performance in OECD Countries - An Institutions Climate Index", CESifo DICE Report 1/2007.

Hoj J., V. Galasso, G. Nicoletti and T-T. Dang (2006), "The political Economy of Structural Refoms : Emprirical Evidence from OECD Countries", OECD Economic Department No. 501.

Lora, E. and U. Panizza (2002), "Structural reforms in Latin America Under Scrutiny", Inter-American Development Bank research Department. 
ANNEX: DESCRIPTION OF THE INDICATORS

\section{POLITICS AND GOVERNANCE}

\begin{tabular}{|c|c|c|c|c|}
\hline SOURCE & INDICATOR & SHORT DESCRIPTION & SCOPE & TYPE \\
\hline \multirow[t]{5}{*}{$\begin{array}{l}\text { *World Bank } \\
\text { Governance matters } \\
\text { http://info.worldbank.org/governa } \\
\text { nce/wgi/resources.htm }\end{array}$} & & $\begin{array}{l}\text { Composite indicators - weighted averages of the underlying } \\
\text { data, with weights reflecting the precision of the individual data } \\
\text { sources. Underlying data are coming from expert assessment } \\
\text { and surveys of firms and individuals from different data sources } \\
\text { and produced by different institutions. } \\
\text { Confidence interval for each score for a given year is given. }\end{array}$ & $\begin{array}{l}\text { Between 204 and } 207 \\
\text { countries in } 2004 \\
\text { Period: } 1996-2007 \\
\text { But indicators are not } \\
\text { comparable over time } \\
\text { Update: Bi-annual } \\
\text { The first "Governance } \\
\text { Matters" paper was released } \\
\text { in 1999. Since then five } \\
\text { updates of "Governance } \\
\text { Matters" have been } \\
\text { published. }\end{array}$ & \\
\hline & Voice and accountability & $\begin{array}{l}\text { The extent to which a country's citizens are able to participate } \\
\text { in selecting their government, as well as freedom of expression, } \\
\text { freedom of association, and a free media. }\end{array}$ & & $\begin{array}{l}\text { Perception-based } \\
\text { Policy Indicator }\end{array}$ \\
\hline & $\begin{array}{l}\text { Political stability and } \\
\text { violence }\end{array}$ & $\begin{array}{l}\text { Perceptions of the likelihood that the government will be } \\
\text { destabilized or overthrown by unconstitutional or violent means, } \\
\text { including domestic violence and terrorism. }\end{array}$ & & $\begin{array}{l}\text { Perception-based } \\
\text { Policy Indicator }\end{array}$ \\
\hline & Government effectiveness & $\begin{array}{l}\text { The quality of public services, the quality of the civil service } \\
\text { and the degree of its independence from political pressures, the } \\
\text { quality of policy formulation and implementation, and the } \\
\text { credibility of the government's commitment to such policies. }\end{array}$ & & $\begin{array}{l}\text { Perception-based } \\
\text { Policy Indicator }\end{array}$ \\
\hline & Regulatory quality & The ability of the government to formulate and implement & & Perception-based \\
\hline
\end{tabular}




\begin{tabular}{|c|c|c|c|c|}
\hline & & $\begin{array}{l}\text { sound policies and regulations that permit and promote private } \\
\text { sector development. }\end{array}$ & & Policy Indicator \\
\hline & Rule of law & $\begin{array}{l}\text { The extent to which agents have confidence in and abide by the } \\
\text { rules of society, and in particular the quality of contract } \\
\text { enforcement, the police, and the courts, as well as the likelihood } \\
\text { of crime and violence. }\end{array}$ & & $\begin{array}{l}\text { Perception-based } \\
\text { Policy Indicator }\end{array}$ \\
\hline & Control of corruption & $\begin{array}{l}\text { The extent to which public power is exercised for private gain, } \\
\text { including both petty and grand forms of corruption, as well as } \\
\text { "capture" of the state by elites and private interests. }\end{array}$ & & $\begin{array}{l}\text { Perception-based } \\
\text { Policy Indicator }\end{array}$ \\
\hline World Bank & $\begin{array}{l}\text { Country Policy and } \\
\text { Institutional Assessment } \\
\text { (CPIA) } \\
\text { http://web.worldbank.org/ } \\
\text { WBSITE/EXTERNAL/EXT } \\
\text { ABOUTUS/IDA/0,,content } \\
\text { MDK:20189503 menuPK: } \\
\text { 2607492 pagePK:512361 } \\
\text { 75 piPK:437394 theSiteP } \\
\text { K:73154,00.html }\end{array}$ & $\begin{array}{l}16 \text { criteria divided in } 4 \text { clusters: economic management; } \\
\text { structural policies; policies for social inclusion and equity; } \\
\text { public sector management and institutions. } \\
\text { The World Bank country team gives a score from } 1 \text { to } 6 \text { to each } \\
\text { criterion and give each cluster the same weight. }\end{array}$ & $\begin{array}{l}\text { Period: Since } 1977 \\
\text { But individual country data } \\
\text { were disclosed only since } \\
2005 \\
\text { Annual update }\end{array}$ & $\begin{array}{l}\text { Perception-based } \\
\text { Policy Indicator }\end{array}$ \\
\hline $\begin{array}{l}\text { International Country Guide Risk } \\
\text { (ICGR) } \\
\text { http://www.prsgroup.com/ICRG_ } \\
\text { Methodology.aspx }\end{array}$ & & $\begin{array}{l}\text { Predictive tool for international investments. } \\
\text { The International Country Risk Guide (ICRG) rating comprises } \\
22 \text { variables in three subcategories of risk: political, financial, } \\
\text { and economic. } \\
\text { ICRG's financial and economic-risk assessments rely entirely } \\
\text { on objective measurements. These include the ratios of a } \\
\text { country's foreign debt to its GDP, its foreign debt-service and } \\
\text { its current-account balance to its exports, its net international } \\
\text { liquidity to imports, its budget balance to GDP and its levels of } \\
\text { growth, inflation and GDP per capita. } \\
\text { ICRG's political-risk assessments rely entirely on experts' } \\
\text { subjective interpretations of pre-specified risk "components" } \\
\text { whose pre-determined weights are made the same for all } \\
\text { countries to facilitate comparison across countries and over } \\
\text { time. It comprises: the ability for the government to stay in }\end{array}$ & $\begin{array}{l}140 \text { countries ( }+20 \text { countries } \\
\text { on an annual basis) } \\
\text { Period: Annual Data from } \\
1984 \text { can be available for } \\
\text { research at a lower cost } \\
\text { (exclude the recent year) } \\
\text { Updated every month }\end{array}$ & $\begin{array}{l}\text { Fact and Perception- } \\
\text { based } \\
\text { Policy and Outcome } \\
\text { indicators }\end{array}$ \\
\hline
\end{tabular}




\begin{tabular}{|c|c|c|c|c|}
\hline & & $\begin{array}{l}\text { office and to carry out its declared programme; socio-economic } \\
\text { conditions (unemployment etc...), other factors affecting } \\
\text { investment risks (contract viability, expropriation...); internal } \\
\text { and external political violence and conflict; corruption; military } \\
\text { in politics; religious and ethnic tensions; democratic } \\
\text { accountability; bureaucratic quality; strength and impartiality of } \\
\text { the legal system and popular observance of the law. }\end{array}$ & & \\
\hline $\begin{array}{l}\text { Economist Intelligence Unit } \\
\text { http://www.eiu.com/site_info.asp? } \\
\text { info_name=sovereign_ratings }\end{array}$ & $\begin{array}{l}\text { *Sovereign ratings } \\
\text { (but not included in the } \\
\text { database) }\end{array}$ & $\begin{array}{l}\text { The Country Risk Service publishes regular ratings. The } \\
\text { sovereign rating measures the risk of a build-up in arrears of } \\
\text { principal and/or interest on foreign- and/or local-currency debt } \\
\text { that is the direct obligation of the sovereign or guaranteed by the } \\
\text { sovereign. }\end{array}$ & $\begin{array}{l}120 \text { Countries } \\
\text { The ratings for emerging } \\
\text { markets are updated } \\
\text { monthly while those for } \\
\text { most developed countries } \\
\text { are updated bi-annually. }\end{array}$ & $\begin{array}{l}\text { Fact and Perception- } \\
\text { based } \\
\text { Outcome indicators }\end{array}$ \\
\hline Global Insight & $\begin{array}{l}\text { Global Risk services } \\
\text { www.globalinsight.com }\end{array}$ & $\begin{array}{l}\text { It measures specific investment risks on a country-by-county } \\
\text { basis using } 51 \text { precisely defined risk factors-from immediate } \\
\text { risks such as tax policies and currency depreciation, to } \\
\text { secondary risks including terrorism and trade conflicts. } 12 \\
\text { investments types are assessed. }\end{array}$ & 140 countries & \\
\hline Ifo institute for economic research & $\begin{array}{l}\text { World Economic Survey } \\
\text { (WES) }\end{array}$ & $\begin{array}{l}\text { WES data survey different dimensions of economic } \\
\text { environment, such as "the lack of confidence in government's } \\
\text { economic policy", "political instability", and "legal and } \\
\text { administrative restrictions for foreign firms to invest in these } \\
\text { countries and/or repatriate profits". }\end{array}$ & $\begin{array}{l}\text { Period: Data available since } \\
1992\end{array}$ & $\begin{array}{l}\text { Perception-based } \\
\text { Policy Indicator }\end{array}$ \\
\hline $\begin{array}{l}\text { Gallup World Poll } \\
\text { www.gallupworldpoll.com }\end{array}$ & National Leadership Index & $\begin{array}{l}\text { Defined by the confidence people have in key institutions. } \\
\text { Questions in this index measure approval of national } \\
\text { governments and confidence in elections, judicial systems, and } \\
\text { the military. }\end{array}$ & $\begin{array}{l}140 \text { countries } \\
\text { The first round of data } \\
\text { collection was carried out in } \\
\text { late } 2005 \text { and } 2006 \text {. Citizens } \\
\text { are continuously surveyed } \\
\text { based on a telephone or } \\
\text { face-to-face interview. }\end{array}$ & $\begin{array}{l}\text { Perception-based } \\
\text { Policy Indicator }\end{array}$ \\
\hline $\begin{array}{l}\text { Gallup World Poll } \\
\text { www.gallupworldpoll.com }\end{array}$ & Law and Order Index & $\begin{array}{l}\text { This index represents the security level that citizens observe for } \\
\text { themselves and their families. Questions in this index measure } \\
\text { confidence in local police, perceptions of safety, and specific } \\
\text { problems such as money or property being stolen. }\end{array}$ & $\begin{array}{l}140 \text { countries } \\
\text { The first round of data } \\
\text { collection was carried out in } \\
\text { late } 2005 \text { and } 2006 \text {. Citizens }\end{array}$ & $\begin{array}{l}\text { Perception-based } \\
\text { Policy Indicator }\end{array}$ \\
\hline
\end{tabular}




\begin{tabular}{|c|c|c|c|c|}
\hline & & & $\begin{array}{l}\text { are continuously surveyed } \\
\text { based on a telephone or } \\
\text { face-to-face interview. }\end{array}$ & \\
\hline $\begin{array}{l}\text { Gallup World Poll } \\
\text { www.gallupworldpoll.com }\end{array}$ & Engaged Citizens Index & $\begin{array}{l}\text { Items in the Engaged Citizens Index focus on respondents' } \\
\text { satisfaction with their communities, and their inclination to } \\
\text { volunteer their time, money, or assistance to others. Questions } \\
\text { in this index gauge satisfaction with community, personal } \\
\text { freedoms, generosity, and respect for minorities and other social } \\
\text { groups. }\end{array}$ & $\begin{array}{l}140 \text { countries } \\
\text { The first round of data } \\
\text { collection was carried out in } \\
\text { late } 2005 \text { and } 2006 \text {. Citizens } \\
\text { are continuously surveyed } \\
\text { based on a telephone or } \\
\text { face-to-face interview. }\end{array}$ & $\begin{array}{l}\text { Perception-based } \\
\text { Policy Indicator }\end{array}$ \\
\hline $\begin{array}{l}\text { Gallup World Poll } \\
\text { www.gallupworldpoll.com }\end{array}$ & $\begin{array}{l}\text { Community Quality of } \\
\text { Life Index }\end{array}$ & $\begin{array}{l}\text { The Community Quality of Life Index is a combination of many } \\
\text { subindexes covering all aspects of community life from the } \\
\text { perspective of the people who live there. Questions in this index } \\
\text { measure overall satisfaction with community as well as } \\
\text { satisfaction with community jobs, healthcare, transportation, } \\
\text { appearance, education, leadership, housing, and environmental } \\
\text { quality. }\end{array}$ & $\begin{array}{l}140 \text { countries } \\
\text { The first round of data } \\
\text { collection was carried out in } \\
\text { late } 2005 \text { and } 2006 \text {. Citizens } \\
\text { are continuously surveyed } \\
\text { based on a telephone or } \\
\text { face-to-face interview }\end{array}$ & $\begin{array}{l}\text { Perception-based } \\
\text { Policy Indicator }\end{array}$ \\
\hline $\begin{array}{l}\text { Gallup World Poll } \\
\text { www.gallupworldpoll.com }\end{array}$ & Religiosity Index & $\begin{array}{l}\text { The Religiosity Index is a measure of the importance of religion } \\
\text { and attendance of religious services. Questions in this index } \\
\text { measure citizens' self-reported importance of religion and } \\
\text { religious service attendance. }\end{array}$ & $\begin{array}{l}140 \text { countries } \\
\text { The first round of data } \\
\text { collection was carried out in } \\
\text { late } 2005 \text { and } 2006 \text {. Citizens } \\
\text { are continuously surveyed } \\
\text { based on a telephone or } \\
\text { face-to-face interview }\end{array}$ & $\begin{array}{l}\text { Perception-based } \\
\text { Policy Indicator }\end{array}$ \\
\hline $\begin{array}{l}\text { Gallup World Poll } \\
\text { www.gallupworldpoll.com }\end{array}$ & Tolerance Index & $\begin{array}{l}\text { The Tolerance Index measures overall perceived openness to } \\
\text { diversity in respondents' communities. Questions in this index } \\
\text { gauge citizens' opinions about helping strangers and whether } \\
\text { their communities are good places for racial and ethnic } \\
\text { minorities, gay and lesbian people, and immigrants to live. }\end{array}$ & $\begin{array}{l}140 \text { countries } \\
\text { The first round of data } \\
\text { collection was carried out in } \\
\text { late } 2005 \text { and } 2006 \text {. Citizens } \\
\text { are continuously surveyed } \\
\text { based on a telephone or } \\
\text { face-to-face interview }\end{array}$ & $\begin{array}{l}\text { Perception-based } \\
\text { Policy Indicator }\end{array}$ \\
\hline Word Development Indicator & ${ }^{*}$ Corruption index & $\begin{array}{l}\text { It is the percentage of managers surveyed ranking this as a } \\
\text { major business constraint. }\end{array}$ & $\begin{array}{l}2006 \text { for } 36 \text { countries } \\
\text { (mostly non-OECD) }\end{array}$ & Perception-based \\
\hline
\end{tabular}


ECO/WKP(2009)17

\begin{tabular}{|c|c|c|c|c|}
\hline & & & & Policy Indicator \\
\hline Transparency International & $\begin{array}{l}{ }^{*} \text { Corruption perceptions } \\
\text { index } \\
\text { http://www.transparency.o } \\
\text { rg/policy_research/surveys } \\
\text { _indices/about }\end{array}$ & $\begin{array}{l}\text { The Transparency International Corruption Perceptions Index } \\
\text { ranks countries in terms of the degree to which corruption is } \\
\text { perceived to exist among public officials and politicians. It is a } \\
\text { composite index, a poll of polls, drawing on corruption-related } \\
\text { data from expert and business surveys carried out by a variety of } \\
\text { independent and reputable institutions. The CPI reflects views } \\
\text { from around the world, including those of experts who are } \\
\text { living in the countries evaluated. }\end{array}$ & $\begin{array}{l}\text { The } 2007 \text { CPI ranks } 180 \\
\text { countries } \\
\text { The country sample change } \\
\text { every year } \\
\text { Period: first released in } \\
1995 \\
\text { Not comparable over time } \\
\begin{array}{l}\text { Every year but the coverage } \\
\text { of countries can differ }\end{array}\end{array}$ & $\begin{array}{l}\text { Perception-based } \\
\text { Policy Indicator }\end{array}$ \\
\hline Transparency International & $\begin{array}{l}\text { Global_ corruption } \\
\text { barometers } \\
\text { http://www.transparency.o } \\
\text { rg/policy_research/surveys } \\
\text { indices/about }\end{array}$ & $\begin{array}{l}\text { A public opinion survey that assesses the general public's } \\
\text { perception and experience of corruption and expectation about } \\
\text { future experience in more than } 60 \text { countries around the world } \\
\text { covering up to } 50000 \text { people. } \\
\text { Disaggregated data per countries and questions are provided. } \\
\text { The data distinguished between corruption in public and private } \\
\text { institutions and between petty and grand corruption. }\end{array}$ & 64 countries in 2003 & $\begin{array}{l}\text { Perception-based } \\
\text { Policy Indicator }\end{array}$ \\
\hline Transparency International & $\begin{array}{l}\text { *Bribe payer index } \\
\text { http://www.transparency.o } \\
\text { rg/policy_research/surveys } \\
\text { indices/bpi }\end{array}$ & $\begin{array}{l}\text { The supply side of corruption and ranks corruption by source } \\
\text { country and industry sector. The purpose is to rank leading } \\
\text { exporting countries in terms of the degree to which international } \\
\text { companies with their headquarters in those countries are likely } \\
\text { to pay bribes to senior public officials in key emerging market } \\
\text { economies. } \\
\text { The question 'In the business sectors with which you are most } \\
\text { familiar, please indicate how likely companies from the } \\
\text { following countries are to pay or offer bribes to win or retain } \\
\text { business in this country?' is used to determine the ranking on } \\
\text { the Bribe Payers Index. The survey asks respondents in } \\
\text { emerging markets to rate the bribe paying behaviour of } \\
\text { companies from developed countries. } \\
\text { The scale used runs from } 0 \text { (indicating certain to bribe) to } 10 \\
\text { (indicating no bribery will be offered). }\end{array}$ & $\begin{array}{l}29 \text { countries (not all OECD) } \\
\text { Period: } 2002 \text { and } 2006\end{array}$ & $\begin{array}{l}\text { Perception-based } \\
\text { Policy Indicator }\end{array}$ \\
\hline Global integrity & $\begin{array}{l}\text { *Global integrity index } \\
\text { (but not included in the } \\
\text { database) }\end{array}$ & $\begin{array}{l}\text { The Global Integrity Index assesses the existence, effectiveness, } \\
\text { and citizen access to key national-level anti-corruption } \\
\text { mechanisms used to hold governments accountable. The Global } \\
\text { Integrity Index is generated by aggregating more than } 300\end{array}$ & $\begin{array}{l}41 \text { countries } \\
\text { Updated every three years }\end{array}$ & $\begin{array}{l}\text { Fact and } \\
\text { Perception-based } \\
\text { Policy Indicator } \\
\end{array}$ \\
\hline
\end{tabular}




\begin{tabular}{|c|c|c|c|c|}
\hline & $\begin{array}{l}\text { http://report.globalintegrity } \\
\text {.org/globalIndex.cfm }\end{array}$ & $\begin{array}{l}\text { Integrity Indicators systematically gathered for each country } \\
\text { covered. } \\
\text { The Integrity Indicators break down that "access" into a number } \\
\text { of categories and questions, ranging from inquiries into electoral } \\
\text { practices and media freedom to budget transparency and } \\
\text { conflicts of interests regulations. These concepts are measured } \\
\text { by looking not only at what laws or institutions are "on the } \\
\text { books" but by assessing their staffing levels, budget levels, } \\
\text { political independence, and citizen access to the most important } \\
\text { anticorruption mechanisms. } \\
\text { Several rounds of review are conducted at the international level } \\
\text { to ensure that cross-country comparisons are valid. In addition, } \\
\text { all assessments are reviewed by a country-specific, double-blind } \\
\text { peer review panel comprising additional local and international } \\
\text { subject matter experts. } \\
\text { http://report.globalintegrity.org/methodology/whitepaper.cfm }\end{array}$ & & \\
\hline $\begin{array}{l}\text { Gallup World Poll } \\
\text { www.gallupworldpoll.com }\end{array}$ & Corruption Index & $\begin{array}{l}\text { The Corruption Index assesses the degree to which respondents } \\
\text { perceive corruption within public and private institutions. } \\
\text { Questions in this index measure corruption in businesses and } \\
\text { government, among other areas. }\end{array}$ & $\begin{array}{l}140 \text { countries } \\
\text { The first round of data } \\
\text { collection was carried out in } \\
\text { late } 2005 \text { and } 2006 \text {. Citizens } \\
\text { are continuously surveyed } \\
\text { based on a telephone or } \\
\text { face-to-face interview }\end{array}$ & Perception-based \\
\hline Kaufman (2004) & $\begin{array}{l}\text { Legal and } \\
\text { corruption indices }\end{array}$ & $\begin{array}{l}\text { These indices are constructed by averaging the answer to the } \\
\text { Executive Opinion Survey questionnaire from the World } \\
\text { Economic Forum. }\end{array}$ & 104 countries & $\begin{array}{l}\text { Perception-based } \\
\text { Policy indicator }\end{array}$ \\
\hline $\begin{array}{l}\text { OECD "Management in } \\
\text { Government: } \\
\text { Country Data" Comparative } \\
\text { November 2005 } \\
\text { launched in } \\
\text { http://www.oecd.org/document/12 } \\
\text { 10,3343,en_2649_33735_3768852 } \\
\text { 4_1_1_1_00.html }\end{array}$ & & $\begin{array}{l}\text { First publication of government at a glance is planned for } 2009 \text {. } \\
\text { The project will encompass six categories of variables: } \\
\text { revenues; inputs; public sector processes; outputs; outcomes; } \\
\text { and antecedents or constraints that contextualise government } \\
\text { efficiency and effectiveness. } \\
\text { The project's approach is incremental, starting from existing } \\
\text { data and statistics and gathering new data when and if necessary } \\
\text { and at minimal cost. }\end{array}$ & Bi-annual updates & $\begin{array}{l}\text { Perception-based } \\
\text { Policy and Outcome } \\
\text { indicators }\end{array}$ \\
\hline
\end{tabular}


ECO/WKP(2009)17

\begin{tabular}{|c|c|c|c|c|}
\hline & & & & \\
\hline $\begin{array}{l}\text { Center on Budget and policy } \\
\text { priorities }\end{array}$ & $\begin{array}{l}\text { *Open budget index } \\
\text { http://www.openbudgetind } \\
\text { ex.org/ }\end{array}$ & $\begin{array}{l}\text { The Open Budget Index provides comprehensive practical } \\
\text { information to gauge a government's commitment to budget } \\
\text { transparency and accountability. The } 2006 \text { Index was calculated } \\
\text { from the answers to a questionnaire completed by } 59 \text { in-country } \\
\text { researchers around the world. } \\
\text { http://www.openbudgetindex.org/materials.htm }\end{array}$ & $\begin{array}{l}59 \text { countries in } 2006 ; \\
\text { expected for } 2008 \\
\text { Period: } 2006\end{array}$ & $\begin{array}{l}\text { Perception-based } \\
\text { Policy Indicator }\end{array}$ \\
\hline Heritage Foundation & Index of fiscal freedom & $\begin{array}{l}\text { The index weights equally three quantitative components using } \\
\text { a quadratic cost function: the top tax rate on individual income, } \\
\text { the top tax rate on corporate income and total tax revenue as a } \\
\text { percentage of GDP. Data used from the computation are taken } \\
\text { from a variety of sources, inclusing OECD data. }\end{array}$ & $\begin{array}{l}\text { Country coverage varies but } \\
\text { in general around } 160 \\
\text { countries } \\
\text { Period } 1995 \text { to } 2008\end{array}$ & $\begin{array}{l}\text { Perception based } \\
\text { Policy indicator }\end{array}$ \\
\hline European Commission & $\begin{array}{l}\text { Index of public finance } \\
\text { quality }\end{array}$ & $\begin{array}{l}\text { Composite indicators have been constructed along several } \\
\text { dimensions: size of government, fiscal position and } \\
\text { sustainability, composition, efficiency and effectiveness of } \\
\text { expenditure, structure and efficiency of revenue systems and } \\
\text { fiscal governance. These indicators are constructed using } 81 \\
\text { variables. } \\
\text { Several weighting system have been tested and the methodolie } \\
\text { is still under discussion. }\end{array}$ & $\begin{array}{l}\text { EU countries } \\
\text { The project is underway }\end{array}$ & $\begin{array}{l}\text { Fact-based } \\
\text { Policy Indicator }\end{array}$ \\
\hline OECD & $\begin{array}{l}\text { Regulatory Management } \\
\text { System Database }\end{array}$ & $\begin{array}{l}\text { Include } 16 \text { dimension on regulatory policies, regulatory } \\
\text { institutions, regulatory procedures and regulator tools. A } \\
\text { summary indicator has been constructed using Principal } \\
\text { Analysis Component. }\end{array}$ & $\begin{array}{l}27 \text { countries } \\
\text { Data for } 1998 \text { and } 2005 \\
\text { Interpolated data in-between }\end{array}$ & $\begin{array}{l}\text { Fact based } \\
\text { Policy variable }\end{array}$ \\
\hline \multirow[t]{3}{*}{ OECD } & $\begin{array}{l}\text { Tax database } \\
\text { http://www.oecd.org/docu } \\
\text { ment/60/0,3343,en_2649_- } \\
\text { 34897_1942460_1_1_1_1, } \\
\text { 00.html }\end{array}$ & $\begin{array}{l}\text { This database compiles tax data from various OECD } \\
\text { publications, in particular Taxing wages. It gathered tax rates } \\
\text { regarding wage taxation, corporate and capital income taxation, } \\
\text { social contribution and value added tax. }\end{array}$ & $\begin{array}{l}\text { OECD countries } \\
\text { Period varies with the data }\end{array}$ & $\begin{array}{l}\text { Fact based } \\
\text { Policy variable }\end{array}$ \\
\hline & Consumption trends & $\begin{array}{l}\text { This publication presents data on different consumption taxes, } \\
\text { as well as an indicator of efficiency (c-index) and environmental } \\
\text { taxes. }\end{array}$ & $\begin{array}{l}\text { OECD countries } \\
\text { Period } 1995 \text { to } 2003\end{array}$ & $\begin{array}{l}\text { Fact-based } \\
\text { Policy and performace } \\
\text { indicator }\end{array}$ \\
\hline & Revenue statistics & This database contains data on tax levels and structures. Data & OECD countries & Fact-based \\
\hline
\end{tabular}




\begin{tabular}{|c|c|c|c|c|}
\hline & $\begin{array}{l}\text { http://www.oecd.org/docu } \\
\text { ment } / 58 / 0,3343 \text {,en_2649_- } \\
\text { 34533_39498298_1_1_1_- } \\
\text { 1,00.html }\end{array}$ & $\begin{array}{l}\text { are also avalaible by sub-sector, as well as data on non-tax } \\
\text { revenue and grants. }\end{array}$ & Period 1965-2005 & $\begin{array}{l}\text { Policy and performace } \\
\text { indicator }\end{array}$ \\
\hline CD Howe & $\begin{array}{l}\text { METR on capital } \\
\text { http://www.cdhowe.org/pd } \\
\text { f/ebrief_63.pdf }\end{array}$ & $\begin{array}{l}\text { Marginal effective tax rates on capital investments incorporate } \\
\text { corporate income taxes, sales taxes on capital purchases and } \\
\text { other capital-related taxes including asset and net worth taxes, } \\
\text { stamp duties on securities, taxes on contributions to equity. } \\
\text { Special tax holiday regimes operating in some countries are not } \\
\text { included in the analysis. Property taxes are not included due to } \\
\text { lack of data. }\end{array}$ & $\begin{array}{l}80 \text { countries } \\
\text { Period 2003-2008 } \\
\text { Updated every year }\end{array}$ & $\begin{array}{l}\text { Fat-based } \\
\text { Policy indicator }\end{array}$ \\
\hline *Heritage Foundation & Property right index & $\begin{array}{l}\text { This indicator scores the degree to which a country's laws } \\
\text { protect private property rights and the degree to which its } \\
\text { government enforces those laws. It also assesses the likelihood } \\
\text { that private property will be expropriated and analyses the } \\
\text { independence of the judiciary, the existence of corruption within } \\
\text { the juridiciary and the ability of individuals and business to } \\
\text { enforce contracts. The authors grade each countries using } \\
\text { information on whether private property is guaranteed by the } \\
\text { government, the court system enforces contracts efficiently and } \\
\text { quickly, the justice system punishes those who unlawfully } \\
\text { confiscate private property, there is no corruption or } \\
\text { expropriation. } \\
\text { The authors use several sources, in priority data from Economist } \\
\text { Intelligence Unit as from the US Department of Commerce or } \\
\text { of States. }\end{array}$ & $\begin{array}{l}103 \text { countries } \\
\text { Period: } 1997\end{array}$ & $\begin{array}{l}\text { Fact and Perception- } \\
\text { based } \\
\text { Policy Indicator }\end{array}$ \\
\hline $\begin{array}{l}\text { Ginarte and Park (1997) and } \\
\text { updated in Park and Singh (2002) }\end{array}$ & $\begin{array}{l}\text { Intellectual property right } \\
\text { index }\end{array}$ & $\begin{array}{l}\text { The index is based on five aspects of national patent systems, } \\
\text { with each country being assigned a score of between } 0 \text { and } 1 \\
\text { according to the coverage, the duration and the enforcement of } \\
\text { patent rights, membership of international treaties and } \\
\text { restrictions placed on the use of patent rights. The score for each } \\
\text { category is based on the weighted sum of the scores for a } \\
\text { number of additional subcomponents. }\end{array}$ & $\begin{array}{l}\text { Data are available at five- } \\
\text { year intervals since } 1980\end{array}$ & $\begin{array}{l}\text { Fact and perception } \\
\text { based } \\
\text { Policy Indicator }\end{array}$ \\
\hline Johnson et al. (2002) & $\begin{array}{l}\text { Insecurity of property right } \\
\text { index }\end{array}$ & $\begin{array}{l}\text { Different indices are constructed using the firms answers to a } \\
\text { questionnaire. The first one combines the three property-rights }\end{array}$ & $\begin{array}{lll}5 & \text { Eastern economies } \\
\text { (Poland, Slovakia, Romania, }\end{array}$ & $\begin{array}{l}\text { Perception based } \\
\text { Policy Indicator }\end{array}$ \\
\hline
\end{tabular}


ECO/WKP(2009)17

\begin{tabular}{|c|c|c|c|c|}
\hline & & $\begin{array}{l}\text { questions - extralegal payments for licenses, extralegal } \\
\text { payments for services, and paying for protection - into an } \\
\text { additive index of property-rights insecurity for each firm. A } \\
\text { higher value of this index therefore represents less secure } \\
\text { property rights. } \\
\text { An alternative index for property rights insecurity is equal to } \\
\text { one if firms make any one of the three types of payments and } \\
\text { zero otherwise. }\end{array}$ & $\begin{array}{l}\text { Russia and Ukraine) } \\
\text { One-off study } 1997\end{array}$ & \\
\hline World Bank Doing Business & $\begin{array}{l}\text { Strengh of investor } \\
\text { protection index }\end{array}$ & $\begin{array}{l}\text { The strength of investor protection index is the average of } \\
\text { the extent of disclosure index, the extent of director liability } \\
\text { index and the ease of shareholder suits index. The index } \\
\text { ranges from } 0 \text { to } 10 \text {, with higher values indicating more investor } \\
\text { protection. } \\
\text { Data come from a survey of corporate lawyers and are based on } \\
\text { security regulation, companies laws and court rules of evidence. }\end{array}$ & $\begin{array}{l}178 \text { economies } \\
\text { Updated every year }\end{array}$ & $\begin{array}{l}\text { Perception-based } \\
\text { Policy indicator }\end{array}$ \\
\hline Reporters Without Borders & $\begin{array}{l}\text { *Worldwide press freedom } \\
\text { index }\end{array}$ & $\begin{array}{l}\text { The report is based on a questionnaire sent to partner } \\
\text { organizations of Reporters Without Borders ( } 14 \text { freedom of } \\
\text { expression groups in five continents) and its } 130 \text { correspondents } \\
\text { around the world, as well as to journalists, researchers, jurists } \\
\text { and human rights activists. } \\
\text { The survey asks questions about direct attacks on journalists } \\
\text { and the media as well as other indirect sources of pressure } \\
\text { against the free press. RWB is careful to note that the index only } \\
\text { deals with press freedom, and does not measure the quality of } \\
\text { journalism. Due to the nature of the survey's methodology based } \\
\text { on individual perceptions, there are often wide contrasts in a } \\
\text { country's ranking from year to year. }\end{array}$ & $\begin{array}{l}172 \text { countries } \\
\text { Period: } 2002 \text { to } 2007\end{array}$ & $\begin{array}{l}\text { Perception-based } \\
\text { Policy Indicator }\end{array}$ \\
\hline Freedom House & & $\begin{array}{l}\text { Rating of political rights and civil liberty on a scale of } 1 \text { (the } \\
\text { highest) to } 7 \text { (the lowest). The average of the two rating is the } \\
\text { country's status: "free }(<3) \text {, partly free }(3<. .<5) \text { and not free } \\
(>5) \text {. The rating is calculated on the basis of in-house experts } \\
\text { subjective perceptions organised according to a checklist of } \\
\text { questions. The list on political rights comprises } 10 \text { questions on } \\
3 \text { categories: electoral process; pluralism and participation; the } \\
\text { functioning of the government. }\end{array}$ & $\begin{array}{l}192 \text { countries } \\
\text { Period: Every years but data } \\
\text { are not comparable over } \\
\text { time (change in } \\
\text { methodology) } \\
\text { Annual update }\end{array}$ & $\begin{array}{l}\text { Perception-based } \\
\text { Policy Indicator }\end{array}$ \\
\hline
\end{tabular}




\begin{tabular}{|c|c|c|c|c|}
\hline & & $\begin{array}{l}\text { The list on civil liberty comprises } 15 \text { questions in four } \\
\text { categories: the freedom of expression and belief; people rights } \\
\text { to associate and organise; the rule of law; and personal } \\
\text { autonomy and individual rights. }\end{array}$ & & \\
\hline $\begin{array}{l}\text { *Polity IV project } \\
\text { http://www.systemicpeace.org/pol } \\
\text { ity/polity4.htm }\end{array}$ & & $\begin{array}{l}\text { Political Regime Characteristics and Transitions, } 1800-2007 \text {, } \\
\text { annual, cross-national, time-series and polity-case formats } \\
\text { coding democratic and autocratic "patterns of authority" and } \\
\text { regime changes in all independent countries with total } \\
\text { population greater than } 500,000 \text { in } 2007 \text {. The aggregate Polity } \\
\text { IV indicator is computed as the difference between two } \\
\text { composite indicators measuring the degree of democracy and } \\
\text { autocracy in a country. Each composite indicator is calculated } \\
\text { by assigning points to institutional features (e.g. on } \\
\text { competitiveness of the executive recruitment). } \\
\text { http://www.systemicpeace.org/inscr/p4manualv2006.pdf }\end{array}$ & $\begin{array}{l}162 \text { countries in } 2007 \\
\text { Period: } 1800 \text { to } 2007\end{array}$ & $\begin{array}{l}\text { Fact-based } \\
\text { Policy Indicator }\end{array}$ \\
\hline $\begin{array}{l}\text { *Henisz (2006) } \\
\text { http://www- } \\
\text { management. wharton.upenn.edu/h } \\
\text { enisz/ }\end{array}$ & Political Constraint & $\begin{array}{l}\text { It is a composed indicator of political risk. It measures the } \\
\text { feasibility of a change in policy given the structure of a nation's } \\
\text { political institutions (the number of veto points) and the } \\
\text { preferences of the actors that inhabit them (the partisan } \\
\text { alignment of various veto points and the heterogeneity or } \\
\text { homogeneity of the preferences within each branch). }\end{array}$ & $\begin{array}{l}235 \text { countries (with some } \\
\text { missing for earlier years) } \\
\text { Period: } 1800-2004\end{array}$ & $\begin{array}{l}\text { Perception-based } \\
\text { Policy Indicator }\end{array}$ \\
\hline $\begin{array}{l}\text { *World Bank- Database of } \\
\text { Political Institutions (DPI) } \\
\text { http://econ.worldbank.org/WBSIT } \\
\text { E/EXTERNAL/EXTDEC/EXTR } \\
\text { ESEARCH/0,,contentMDK:2064 } \\
\text { 9465 pagePK:64214825 piPK:6 } \\
\text { 4214943 theSitePK:469382,00.ht } \\
\text { ml }\end{array}$ & & $\begin{array}{l}\text { DPI contains several indicators regarding Chief Executive } \\
\text { Variables ( i.e. parliamentary system, military chief, nationalist } \\
\text { chief, religious chief, etc.) Party Variables in the Legislature } \\
\text { (Herfindahl Index of parties' concentration, fractionalization, } \\
\text { largest government part that represents any special interest), } \\
\text { Electoral Rules and Number of Elections, Stability (longest } \\
\text { tenure of veto players; number of veto players who drop from } \\
\text { government in any given year) and Federalism. }\end{array}$ & $\begin{array}{l}178 \text { countries } \\
\text { Period: } 1975-2006\end{array}$ & $\begin{array}{l}\text { Fact-based } \\
\text { Policy Indicator }\end{array}$ \\
\hline $\begin{array}{l}\text { Comparative Data feature of ACE } \\
\text { Electoral Knowledge Network. } \\
\text { (formally EPIC project) }\end{array}$ & & $\begin{array}{l}\text { The survey covers } 11 \text { election related topics. It Provide } \\
\text { information about electoral systems, electoral management, } \\
\text { legislative framework, voter registration, voter education and } \\
\text { other related topics. }\end{array}$ & $\begin{array}{l}\text { Over } 180 \text { countries } \\
\text { Work in progress, results } \\
\text { online expected for end- } \\
2008\end{array}$ & $\begin{array}{l}\text { Perception-based } \\
\text { Policy Indicator }\end{array}$ \\
\hline
\end{tabular}


ECO/WKP(2009)17

\begin{tabular}{|c|c|c|c|c|}
\hline $\begin{array}{l}\text { http://aceproject.org/epic- } \\
\text { en/methodology }\end{array}$ & & $\begin{array}{l}\text { The information available on Comparative Data is compiled } \\
\text { through a comprehensive multiple-choice survey about national } \\
\text { elections on a country-by-country basis. The multiple-choice } \\
\text { aspect of the survey allows for comparative statistics. }\end{array}$ & & \\
\hline Global report on conflict & State fragility index & $\begin{array}{l}\text { It combines scores on two essential qualities of state } \\
\text { performance: effectiveness and legitimacy. These two quality } \\
\text { indices combine scores on distinct measures of the key } \\
\text { performance dimensions of security, governance, economics } \\
\text { and social development. }\end{array}$ & $\begin{array}{l}162 \text { countries } \\
\text { Data for } 1995,2001 \text { and } \\
2007\end{array}$ & $\begin{array}{l}\text { Fact-based } \\
\text { Policy Indicator }\end{array}$ \\
\hline $\begin{array}{l}\text { Cingranelli-Richards Human } \\
\text { Rights } \\
\text { www.humanrightsdata.com }\end{array}$ & & $\begin{array}{l}\text { The database describes a wide variety of government human } \\
\text { rights practices (13) including torture, workers' rights, women's } \\
\text { rights, and freedom of religion over a } 26 \text {-year period. } \\
\text { Contains both disaggregated measures of specific human rights } \\
\text { practices, which can either be analyzed separately or combined } \\
\text { into valid and reliable indices, as well as two already- } \\
\text { aggregated indices. } \\
\text { The primary source of information about human rights practices } \\
\text { is obtained from a careful reading of the annual United States } \\
\text { Department of State's Country Reports on Human Rights } \\
\text { Practices. }\end{array}$ & $\begin{array}{l}192 \text { countries } \\
\text { Annual } \\
1981-2006\end{array}$ & $\begin{array}{l}\text { Fact-based } \\
\text { Policy Indicator }\end{array}$ \\
\hline
\end{tabular}

\section{SOCIO ECONOMIC INDICATORS}

\begin{tabular}{|c|c|c|c|c|}
\hline SOURCE & INDICATOR & SHORT DESCRIPTION & SCOPE & TYPE \\
\hline World Bank & $\begin{array}{l}\text { World development } \\
\text { Indicators } 2008 \\
\text { Data available at: } \\
\text { http://ddp- } \\
\text { ext.worldbank.org/ext/DDP } \\
\text { QQ/member.do?method=get } \\
\text { Members }\end{array}$ & $\begin{array}{l}\text { WDI } 2008 \text { includes approx. } 800 \text { indicators in } 87 \text { tables, } \\
\text { organised in six sections: World View, People, Environment, } \\
\text { Economy, States and Markets, and Global Links. }\end{array}$ & $\begin{array}{l}54 \text { time series indicators for } \\
207 \text { countries and } 18 \\
\text { groups, data from } 1990 \text { to } \\
2006\end{array}$ & $\begin{array}{l}\text { Fact-based } \\
\text { Policy and Outcome } \\
\text { indicators }\end{array}$ \\
\hline
\end{tabular}




\begin{tabular}{|c|c|c|c|c|}
\hline $\begin{array}{l}\text { *World Bank, development } \\
\text { economic research group }\end{array}$ & Life expectancy at birth & & $\begin{array}{l}\text { Period:1960-2006 } \\
\text { Countries: } 208\end{array}$ & $\begin{array}{l}\text { Fact-Based } \\
\text { Outcome indicator }\end{array}$ \\
\hline $\begin{array}{l}\text { World bank, development } \\
\text { economic research group }\end{array}$ & Incidence of poverty & & Period: 1981-2004 & $\begin{array}{l}\text { Fact-based } \\
\text { Policy Indicator }\end{array}$ \\
\hline $\begin{array}{l}\text { United Nations Development } \\
\text { Programme } \\
\text { Human Development Index } \\
\text { http://hdr.undp.org/en/statistics/ } \\
\text { indices/hdi/ }\end{array}$ & $\begin{array}{l}\text { *Human development index } \\
\text { Education index }\end{array}$ & $\begin{array}{l}\text { The HDI is a summary composite index that measures a } \\
\text { country's average achievements in three basic aspects of human } \\
\text { development: health, knowledge, and a decent standard of } \\
\text { living. Health is measured by life expectancy at birth; } \\
\text { knowledge is measured by a combination of the adult literacy } \\
\text { rate and the combined primary, secondary, and tertiary gross } \\
\text { enrolment ratio; and standard of living by GDP per capita (PPP } \\
\text { US\$). } \\
\text { The HDI sets a minimum and a maximum for each dimension, } \\
\text { called goalposts, and then shows where each country stands in } \\
\text { relation to these goalposts, expressed as a value between } 0 \text { and } \\
1 \text {. } \\
\text { The educational component of the HDI is comprised of adult } \\
\text { literacy rates and the combined gross enrolment ratio for } \\
\text { primary, secondary and tertiary schooling, weighted to give } \\
\text { adult literacy more significance in the statistic. }\end{array}$ & $\begin{array}{l}176 \text { countries in } 2005 \\
\text { Period: Every five years } \\
\text { from } 1975\end{array}$ & $\begin{array}{l}\text { Fact-based } \\
\text { Policy Indicator }\end{array}$ \\
\hline OECD & $\begin{array}{l}\text { Society at a glance } \\
\text { http://www.oecd.org/docume } \\
\text { nt/24/0,3343,en_2649_34637 } \\
\text { 2671576_1_____1,00.html }\end{array}$ & $\begin{array}{l}\text { This publication reports a wide range of indicators } \\
\text { General Context Indicators: National Income per Capita, Age- } \\
\text { Dependency Rates, Fertility Rates, Migration, Marriage and } \\
\text { Divorce } \\
\text { Self-Sufficiency Indicators: Employment, Unemployment, } \\
\text { Mothers in Paid Employment, Childcare Costs, Tax Wedge on } \\
\text { Labour, Out-of-Work Benefits, Students' Performance } \\
\text { Equity Indicators: Material Deprivation, Earnings Inequality, } \\
\text { Gender Wage Gaps, Intergenerational Mobility, Public Social } \\
\text { Spending, Poverty Persistence, Housing Costs, Old-Age } \\
\text { Pension Replacement Rates } \\
\text { Health Indicators: Life Expectancy, Health Care Expenditure, } \\
\text { Low Birth Weight, Sick-Related Absences from Work, Long- } \\
\text { Term Care Recipients, Health IInequalities } \\
\text { Social Cohesion Indicators: Voting, Prisoners, Suicides, Work } \\
\text { Accidents, Trust in Political Institutions, Life Satisfaction. }\end{array}$ & $\begin{array}{l}\text { OECD countries } \\
\text { Availability depends on the } \\
\text { indicators }\end{array}$ & $\begin{array}{l}\text { Fact-based } \\
\text { Policy and Outcome } \\
\text { indicators }\end{array}$ \\
\hline
\end{tabular}


ECO/WKP(2009)17

\begin{tabular}{|c|c|c|c|c|}
\hline OECD & $\begin{array}{l}\text { Family database } \\
\text { http://www.oecd.org/docume } \\
\text { nt/4/0,3343,en_264934819 } \\
\text { 37836996_1_1_1_1,00.html }\end{array}$ & $\begin{array}{l}\text { The database brings together information from different OECD } \\
\text { databases (for example, the OECD Social Expenditure database, } \\
\text { the OECD Benefits and Wages database, or the OECD } \\
\text { Education database, and databases maintained by other } \\
\text { (international) organisations. In the April } 2008 \text { version } 23 \\
\text { indicators were available on the structure of families, the labour } \\
\text { market situations of families, public policies for families and } \\
\text { children and child outcomes (health, poverty, education, } \\
\text { societal participation). }\end{array}$ & $\begin{array}{l}\text { OECD countries } \\
\text { Availability depends on the } \\
\text { indicators }\end{array}$ & $\begin{array}{l}\text { Fact-based } \\
\text { Policy and Outcome } \\
\text { indicators }\end{array}$ \\
\hline OECD & $\begin{array}{l}\text { Programme for International } \\
\text { Student Assessment (PISA) } \\
\text { http://pisa2006.acer.edu.au/i } \\
\text { nteractive.php }\end{array}$ & $\begin{array}{l}\text { PISA assesses how far students near the end of compulsory } \\
\text { education have acquired some of the knowledge and skills that } \\
\text { are essential for full participation in society. In all cycles, the } \\
\text { domains of reading, mathematical and scientific literacy are } \\
\text { covered not merely in terms of mastery of the school } \\
\text { curriculum, but in terms of important knowledge and skills } \\
\text { needed in adult life. }\end{array}$ & $\begin{array}{l}\text { Coverage has increased over } \\
\text { time: } 43 \text { countries in the } 1 \text { st } \\
\text { assessment in } 2000 \text {, in } 41 \\
\text { countries in 2003, in } 57 \\
\text { countries in the 3rd } \\
\text { assessment in } 2006 \text { and } 62 \\
\text { countries have signed up to } \\
\text { participate in the } 4 \text { th } \\
\text { assessment in } 2009 \text {. } \\
2000,2003,2006 \text {, } \\
\text { Update: next issue will be in } \\
2009\end{array}$ & $\begin{array}{l}\text { Fact-based } \\
\text { Outcome indicator }\end{array}$ \\
\hline OECD & Education at a glance & $\begin{array}{l}\text { The database covers a numbers of areas including education } \\
\text { output and the impact of learning, financial investment in } \\
\text { education, access to education, the learning environment and } \\
\text { organisation of school. }\end{array}$ & $\begin{array}{l}\text { OECD countries } \\
\text { Availability varies variables } \\
\text { and countries } \\
\text { Annual update }\end{array}$ & Fact-based \\
\hline OECD & $\begin{array}{l}\text { Health data } 2008 \\
\text { http://www.ecosante.org/ind } \\
\text { ex2.php?base=OCDE\&langh } \\
=\text { ENG\&langs=ENG }\end{array}$ & $\begin{array}{l}\text { Detailed database covering all the aspects of health from health } \\
\text { status, to heath care resource, expenditure and utilisation and } \\
\text { financing. Social protection, pharmaceutical markets and } \\
\text { demographic aspects are also covered, as well as non medical } \\
\text { determinants of heath. }\end{array}$ & \begin{tabular}{|l} 
OECD countries \\
Period:1960 to 2007 \\
Updated every year
\end{tabular} & $\begin{array}{l}\text { Fact-based } \\
\text { Policy and Outcome } \\
\text { indicators }\end{array}$ \\
\hline OECD & Pensions at a glance & $\begin{array}{l}\text { Includes data on replacement rates, relative pensions levels and } \\
\text { pension wealth. }\end{array}$ & $\begin{array}{l}\text { OECD countries } \\
\text { Period: } \\
\text { Update every } 2 \text { years }\end{array}$ & $\begin{array}{l}\text { Fact based } \\
\text { Policy and performance. }\end{array}$ \\
\hline $\begin{array}{l}\text { UNESCO-OECD-Eurostat } \\
\text { (UOE) data collection }\end{array}$ & $\begin{array}{l}\text { Student enrolment } \\
\text { Foreign and international }\end{array}$ & $\begin{array}{l}\text { The UNESCO/OECD/EUROSTAT (UOE) database on } \\
\text { education statistics is compiled on the basis of national }\end{array}$ & $\begin{array}{l}\text { In general } 54 \text { (including } 30 \\
\text { OECD countries) }\end{array}$ & Fact-based \\
\hline
\end{tabular}


ECO/WKP(2009)17

\begin{tabular}{|c|c|c|c|c|}
\hline $\begin{array}{l}\text { http://www.oecd.org/document/ } \\
\text { 54/0,3343,en_2649_39263238_- } \\
\text { 38082166_1_1_1_1,00.html\#1 }\end{array}$ & $\begin{array}{l}\text { /mobile students enrolled } \\
\text { New entrants by sex and age } \\
\text { Graduates } \\
\text { Education personnel } \\
\text { Expenditure by funding } \\
\text { source and transaction type } \\
\text { Expenditure by nature and } \\
\text { resource category } \\
\text { Students aligned to finance } \\
\text { and personnel data } \\
\text { Total population by sex and } \\
\text { age }\end{array}$ & $\begin{array}{l}\text { administrative sources, reported by Ministries of Education or } \\
\text { National Statistical offices according to international standards, } \\
\text { definitions and classifications. The collected annual data cover } \\
\text { the outputs of educational institutions, the policy levers that } \\
\text { shape educational outputs, the human and financial resources } \\
\text { invested in education, structural characteristics of education } \\
\text { systems, and the economic and social outcomes of education. } \\
\text { The main purpose of this database is to produce and publish } \\
\text { indicators and analysis on the operation, evolution and impact } \\
\text { of education, from early childhood through formal education to } \\
\text { learning and training throughout life. }\end{array}$ & $\begin{array}{l}\text { Coverage of non-member is } \\
\text { less good } \\
\text { Period: } 1998 \text { to } 2005 \\
\text { Last update was done in } \\
\text { Sept } 2006\end{array}$ & $\begin{array}{l}\text { Policy and Outcome } \\
\text { indicators }\end{array}$ \\
\hline $\begin{array}{l}\text { Gallup World Poll } \\
\text { www.gallupworldpoll.com }\end{array}$ & Communications Index & $\begin{array}{l}\text { The intent of the Communications Index is to evaluate the } \\
\text { availability and penetration of communications technology. } \\
\text { Questions in this index measure whether citizens have } \\
\text { televisions, computers, and access to the Internet in their homes. }\end{array}$ & $\begin{array}{l}140 \text { countries } \\
\text { The first round of data } \\
\text { collection was carried out in } \\
\text { late } 2005 \text { and } 2006 \text {. Citizens } \\
\text { are continuously surveyed } \\
\text { based on a telephone or } \\
\text { face-to-face interview }\end{array}$ & $\begin{array}{l}\text { Perception-based } \\
\text { Policy Indicators }\end{array}$ \\
\hline $\begin{array}{l}\text { Gallup World Poll } \\
\text { www.gallupworldpoll.com }\end{array}$ & Economics Index & $\begin{array}{l}\text { The key issues included in this index focus on people's } \\
\text { evaluations and outlook for their standard of living and the } \\
\text { national economic situation. Questions in this index measure } \\
\text { satisfaction with and improvements in standards of living, as } \\
\text { well as national economic conditions. }\end{array}$ & $\begin{array}{l}140 \text { countries } \\
\text { The first round of data } \\
\text { collection was carried out in } \\
\text { late } 2005 \text { and } 2006 \text {. Citizens } \\
\text { are continuously surveyed } \\
\text { based on a telephone or } \\
\text { face-to-face interview }\end{array}$ & $\begin{array}{l}\text { Perception-based } \\
\text { Outcome indicator }\end{array}$ \\
\hline $\begin{array}{l}\text { Gallup World Poll } \\
\text { www.gallupworldpoll.com }\end{array}$ & Health Index & $\begin{array}{l}\text { This index measures personal perceptions of physical and } \\
\text { emotional health. Questions in this index gauge satisfaction } \\
\text { with personal health and citizens' self-reported levels of health, } \\
\text { rest, worry, sadness, and pain. }\end{array}$ & $\begin{array}{l}140 \text { countries } \\
\text { The first round of data } \\
\text { collection was carried out in } \\
\text { late } 2005 \text { and } 2006 \text {. Citizens }\end{array}$ & $\begin{array}{l}\text { Perception-based } \\
\text { Outcome indicator }\end{array}$ \\
\hline
\end{tabular}




\begin{tabular}{|c|c|c|c|c|}
\hline & & & $\begin{array}{l}\text { are continuously surveyed } \\
\text { based on a telephone or } \\
\text { face-to-face interview }\end{array}$ & \\
\hline $\begin{array}{l}\text { Gallup World Poll } \\
\text { www.gallupworldpoll.com }\end{array}$ & Well-Being Index & $\begin{array}{l}\text { Developed in collaboration with the world's foremost } \\
\text { behavioural economists, the Well-Being Index items are used to } \\
\text { rate citizens' current and past quality of life. Questions in this } \\
\text { index measure overall life quality now and five years from now, } \\
\text { as well as citizens' reported incidences of laughter, learning, and } \\
\text { being treated with respect. }\end{array}$ & $\begin{array}{l}140 \text { countries } \\
\text { The first round of data } \\
\text { collection was carried out in } \\
\text { late } 2005 \text { and } 2006 \text {. Citizens } \\
\text { are continuously surveyed } \\
\text { based on a telephone or } \\
\text { face-to-face interview }\end{array}$ & $\begin{array}{l}\text { Perception-based } \\
\text { Outcome indicator }\end{array}$ \\
\hline $\begin{array}{l}\text { Gallup World Poll } \\
\text { www.gallupworldpoll.com }\end{array}$ & Youth Development Index & $\begin{array}{l}\text { The Youth Development Index includes general measures of } \\
\text { "development of youth" and "respect for youth," along with } \\
\text { satisfaction with the educational system. Questions in this index } \\
\text { gauge child treatment, learning opportunities for children, and } \\
\text { satisfaction with schools and education. }\end{array}$ & $\begin{array}{l}140 \text { countries } \\
\text { The first round of data } \\
\text { collection was carried out in } \\
\text { late } 2005 \text { and } 2006 \text {. Citizens } \\
\text { are continuously surveyed } \\
\text { based on a telephone or } \\
\text { face-to-face interview }\end{array}$ & $\begin{array}{l}\text { Perception-based } \\
\text { Outcome indicator }\end{array}$ \\
\hline $\begin{array}{l}\text { Gallup World Poll } \\
\text { www.gallupworldpoll.com }\end{array}$ & Environment Index & $\begin{array}{l}\text { The purpose of the Environment Index is to measure satisfaction } \\
\text { with efforts to deal with environmental issues. Questions in this } \\
\text { index gauge satisfaction with air quality, water quality, and the } \\
\text { overall environmental system. }\end{array}$ & $\begin{array}{l}140 \text { countries } \\
\text { The first round of data } \\
\text { collection was carried out in } \\
\text { late } 2005 \text { and } 2006 \text {. Citizens } \\
\text { are continuously surveyed } \\
\text { based on a telephone or } \\
\text { face-to-face interview }\end{array}$ & $\begin{array}{l}\text { Perception-based } \\
\text { Outcome indicator }\end{array}$ \\
\hline $\begin{array}{l}\text { IEA, Edition } 2007 \\
\text { Available in oecd.stat }\end{array}$ & $\begin{array}{l}\text { CO2 emission from fuel } \\
\text { combustion per capita by } \\
\text { sector (name in oecd.stat: per } \\
\text { capita emission by sector) }\end{array}$ & Emission from fuel combustion & $\begin{array}{l}166 \text { countries } \\
\text { Period: } 1998 \text { to } 2005\end{array}$ & $\begin{array}{l}\text { Fact-based } \\
\text { Perforamnce Indicator }\end{array}$ \\
\hline
\end{tabular}


ECO/WKP(2009)17

\section{LABOUR MARKET}

\begin{tabular}{|c|c|c|c|c|}
\hline SOURCE & INDICATOR & SHORT DESCRIPTION & SCOPE & TYPE \\
\hline \multicolumn{5}{|c|}{$\begin{array}{l}\text { OECD Employment Outlook } \\
\text { http://www.oecd.org/document/ } \\
\text { 34/0,3343,en_2649_33927_409 } \\
\text { 17154_1_1_1_1,00.html\#lmp }\end{array}$} \\
\hline & $\begin{array}{l}\text { Employment protection } \\
\text { legislation }\end{array}$ & $\begin{array}{l}\text { The measure of employment protection developed here refers to } \\
\text { the protection of regular employment and the regulation of } \\
\text { temporary work and is intended to measure the strictness of } \\
\text { EPL. }\end{array}$ & $\begin{array}{l}\text { OECD countries } \\
19901998,2003 \text { and } 2008\end{array}$ & $\begin{array}{l}\text { Fact and } \\
\text { Perception-based } \\
\text { Policy indicator }\end{array}$ \\
\hline & Union Coverage & & & $\begin{array}{l}\text { Fact-based } \\
\text { Policy Indicator }\end{array}$ \\
\hline & Union density & $\begin{array}{l}\text { Trade union density is defined as the percentage of employees } \\
\text { who are members of a trade-union. }\end{array}$ & $\begin{array}{l}\text { OECD countries } \\
1960-2002\end{array}$ & $\begin{array}{l}\text { Fact-based } \\
\text { Policy Indicator }\end{array}$ \\
\hline & Replacement ratio & & & $\begin{array}{l}\text { Fact-based } \\
\text { Outcome indicator }\end{array}$ \\
\hline & Labour market programmes & $\begin{array}{l}\text { Labour market programmes include public employment } \\
\text { services, training, hiring subsidies and direct job creations in the } \\
\text { public sector, as well as unemployment benefits. }\end{array}$ & $\begin{array}{l}\text { OECD countries } \\
\text { Data from } 1998 \text { to } 2006 \text { (vary } \\
\text { depending on the country) }\end{array}$ & $\begin{array}{l}\text { Fact-based } \\
\text { Policy indicator }\end{array}$ \\
\hline & $\begin{array}{l}\text { Involuntary part-time } \\
\text { workers }\end{array}$ & $\begin{array}{l}\text { Involuntary part-time workers are part-timers (working less than } \\
30 \text {-usual hours per week) because they could not find a full-time } \\
\text { job. }\end{array}$ & $\begin{array}{l}\text { OECD countries } \\
2000 \text { to } 2007\end{array}$ & $\begin{array}{l}\text { Fact-based } \\
\text { Outcome indicator }\end{array}$ \\
\hline Economic Outlook & $\begin{array}{l}\text { Hours worked, employment, } \\
\text { unemployment rate, labour } \\
\text { force }\end{array}$ & & $\begin{array}{l}\text { OECD countries and some non- } \\
\text { member } \\
1960-2008 \text {, quarterly data }\end{array}$ & $\begin{array}{l}\text { Fact-based } \\
\text { Outcome indicator }\end{array}$ \\
\hline OECD & Marginal tax on retirement & & Most OECD countries & $\begin{array}{l}\text { Fact-Based } \\
\text { Policy indicator }\end{array}$ \\
\hline Tax and Benefits & Marginal tax rate & $\begin{array}{l}\text { The analysis is done for different family types and income } \\
\text { levels. An individual called average production worker who } \\
\text { works full-time in the manufacturing sector and earns an }\end{array}$ & & $\begin{array}{l}\text { Fact-based } \\
\text { Policy Indicator }\end{array}$ \\
\hline
\end{tabular}


ECO/WKP(2009)17

\begin{tabular}{|c|c|c|c|c|}
\hline & & $\begin{array}{l}\text { average wage is first identified. This worker may claim different } \\
\text { tax reliefs and benefits depending on the personal circumstances } \\
\text { such as marriage and children. For each country, the tax code is } \\
\text { then applied and the worker's net income is computed. }\end{array}$ & & \\
\hline \multirow[t]{2}{*}{ Tax and Benefits } & Marginal tax rate & & & $\begin{array}{l}\text { Fact-based } \\
\text { Policy Indicator }\end{array}$ \\
\hline & $\begin{array}{l}\text { Labour market outcome } \\
\text { indicators }\end{array}$ & $\begin{array}{l}\text { This includes, participation rates, employment rates, } \\
\text { unemployment by age and categories. } \\
\text { Most data are coming from MEI. }\end{array}$ & $\begin{array}{l}\text { OECD countries } \\
\text { Monthly or quarterly updates }\end{array}$ & $\begin{array}{l}\text { Fact based } \\
\text { Outcome indicator }\end{array}$ \\
\hline \multirow[t]{3}{*}{ Social spending database } & & & $\begin{array}{l}24 \text { OECD countries } \\
1980 \text { to } 2003\end{array}$ & $\begin{array}{l}\text { Fact based } \\
\text { Policy indicator }\end{array}$ \\
\hline & $\begin{array}{lll}\begin{array}{l}\text { Active } \\
\text { policies }\end{array} & \text { labour market } \\
\end{array}$ & & & \\
\hline & $\begin{array}{l}\begin{array}{l}\text { Sickness and disability } \\
\text { benefits }\end{array} \\
\end{array}$ & & & \\
\hline Economic Outlook & NAIRU & $\begin{array}{l}\text { Estimated by the Economics Department using a price Phillips } \\
\text { curve estimated using a Kalman filter approach. }\end{array}$ & $\begin{array}{l}\text { 23 OECD countries } \\
\text { Irregular update }\end{array}$ & Estimation \\
\hline OECD & $\begin{array}{l}\text { Minimum wage database } \\
\text { (Info:Himmervol (2007) }\end{array}$ & $\begin{array}{l}\text { Data on gross statutory minimum wage, on relative minimum } \\
\text { wage as a percentage of average wage, labour costs for full-time } \\
\text { minimum wage workers, labour tax on full-time minimum wage } \\
\text { workers. }\end{array}$ & $\begin{array}{l}21 \text { OECD countries } \\
2000-2005\end{array}$ & Fact-based \\
\hline $\begin{array}{l}\text { Allard (2005) Measuring Job } \\
\text { Security Over Time: In Search } \\
\text { of a Historical Indicator. }\end{array}$ & EPL & $\begin{array}{l}\text { Based on the OECD methodology and scoring system, Allard } \\
\text { (2005a) reviews EPL changes and derives time-series for OECD } \\
\text { countries, based on the ILO's International Encyclopedia for } \\
\text { Labor Law and Industrial Relations and offers country scores } \\
\text { for } 1950-2003 \text { at the aggregate level. }\end{array}$ & $\begin{array}{l}\text { OECD countries } \\
1950-2003\end{array}$ & $\begin{array}{l}\text { Fact and } \\
\text { Perception-based }\end{array}$ \\
\hline $\begin{array}{l}\text { Amable et al. (2007) } \\
\text { Employment Performance and } \\
\text { Institutions:New Answers to an } \\
\text { Old Question. IZA Discussion } \\
\text { Paper 2731. }\end{array}$ & EPL & $\begin{array}{l}\text { They use the OECD data as a starting point. To fill the gaps, } \\
\text { they look at the Social Reforms Database maintained by the } \\
\text { Fondazione Rodolfo Debenedetti (FRDB) that collects } \\
\text { information on labor market reforms and assesses their impact } \\
\text { to see whether they have increased or decreased the flexibility } \\
\text { of the system. The authors run OLS regressions with this data to } \\
\text { predict the evolution of the EPL indicator between } 1980 \text { and } \\
2004 \text {. }\end{array}$ & $\begin{array}{l}18 \text { OECD countries } \\
1980-2004\end{array}$ & \\
\hline
\end{tabular}




\begin{tabular}{|c|c|c|c|c|}
\hline $\begin{array}{l}\text { ILO } \\
\text { http://www.ilo.org/global/What } \\
\text {-we_do/Statistics/lang-- } \\
\text { en/index.htm }\end{array}$ & $\begin{array}{l}\text { LABORSTA } \\
\text { http://laborsta.ilo.org/ }\end{array}$ & $\begin{array}{l}\text { Information on employment, unemployment, wages, hours of } \\
\text { work, labor cost, consumer price indices, occupational } \\
\text { injuries,strikes, lockouts, labor protection, worker living } \\
\text { conditions. }\end{array}$ & $\begin{array}{l}200 \text { countries } \\
\text { Period } 1969-2006\end{array}$ & $\begin{array}{l}\text { Fact-based } \\
\text { Policy and } \\
\text { Outcome indicators }\end{array}$ \\
\hline $\begin{array}{l}\text { World competitiveness report } \\
\text { http://www.imd.ch/research/pub } \\
\text { lications/wcy/World- } \\
\text { Competitiveness-Yearbook- } \\
\text { 2008-Results.cfm }\end{array}$ & & $\begin{array}{l}\text { Data on Working hours, Labor relations, Worker motivation, } \\
\text { industrial disputes and employee training are collected through } \\
\text { a questionnaire. Data on costs and avalaibility of skills are also } \\
\text { avalaible. } \\
\text { The WCY uses different types of data to measure quantify able } \\
\text { and qualitative issues separately. Statistical indicators are } \\
\text { acquired from international, national and regional organisations, } \\
\text { private institutions and } 52 \text { Partner Institutes worldwide. An } \\
\text { Executive Opinion Survey is also used to complement the } \\
\text { statistics. }\end{array}$ & $\begin{array}{l}55 \text { countries } \\
\text { Since } 1989 \\
\text { Updated every year }\end{array}$ & $\begin{array}{l}\text { Fact and } \\
\text { perception based } \\
\text { indicators }\end{array}$ \\
\hline $\begin{array}{l}\text { Gallup World Poll } \\
\text { www.gallupworldpoll.com }\end{array}$ & Work Index & $\begin{array}{l}\text { Items in this index focus on the degree of personal engagement } \\
\text { at work -- whether it is paid labor or a part of day-to-day family } \\
\text { subsistence. Questions in this index measure citizens' work and } \\
\text { job classifications, their job satisfaction, and their ability to do } \\
\text { what they do best every day. }\end{array}$ & $\begin{array}{l}140 \text { countries } \\
\text { The first round of data } \\
\text { collection was carried out in late } \\
2005 \text { and } 2006 \text {. Citizens are } \\
\text { continuously surveyed based on } \\
\text { a telephone or face-to-face } \\
\text { interview }\end{array}$ & $\begin{array}{l}\text { Perception-based } \\
\text { Outcome indicator }\end{array}$ \\
\hline European Commission & $\begin{array}{l}\text { LABREF database } \\
\text { http://ec.europa.eu/economy } \\
\text { finance/db_indicators/db_in } \\
\text { dicators8638_en.htm }\end{array}$ & $\begin{array}{l}\text { LABREF covers nine broad policy areas: labour taxation, } \\
\text { unemployment and welfare-related benefits, active labour } \\
\text { market programmes, employment protection legislation, early- } \\
\text { retirement and disability schemes, pension systems, wage- } \\
\text { bargaining framework, working time organisation, immigration } \\
\text { and labour-mobility policies. } \\
\text { LABREF compile difference databases from the OECD, the } \\
\text { IMF, ILO, EIRO as well as questionnaires filled in by member } \\
\text { states }\end{array}$ & $\begin{array}{l}25 \text { EU Member States and the } \\
\text { years } 2000-2006 \\
\text { Annually updated }\end{array}$ & $\begin{array}{l}\text { Perception-based } \\
\text { Policy and } \\
\text { outcome indicator }\end{array}$ \\
\hline Heritage Foundation & $\begin{array}{l}\text { Index of Economic } \\
\text { Freedom }\end{array}$ & $\begin{array}{l}\text { It provides information on the relative degree of government } \\
\text { control over wages and prices. }\end{array}$ & $\begin{array}{l}\text { Annual data available since } \\
1995 \text { for } 161 \text { countries }\end{array}$ & $\begin{array}{l}\text { Fact and } \\
\text { Perception-based } \\
\text { Policy Indicator }\end{array}$ \\
\hline
\end{tabular}


PRODUCT MARKET

\begin{tabular}{|c|c|c|c|c|}
\hline SOURCE & INDICATOR & SHORT DESCRIPTION & SCOPE & TYPE \\
\hline \multirow[t]{2}{*}{ OECD } & $\begin{array}{l}\text { Product Market Regulation } \\
\text { index }\end{array}$ & $\begin{array}{l}\text { These are economy-wide indicators } \\
\text { The indicators are based on qualitative information collected } \\
\text { through an ad hoc questionnaire to OECD countries. This } \\
\text { information is coded by assigning a numerical value to each of } \\
\text { the possible responses to a given question. Quantitative } \\
\text { information is divided into classes using a system of thresholds. } \\
\text { The information is then normalised over a scale of zero to six, } \\
\text { reflecting increasing restrictiveness of regulatory provisions for } \\
\text { competition. These data are then aggregated into the } 16 \text { low- } \\
\text { level indicators by assigning subjective weights to the various } \\
\text { regulatory provisions. The aggregate indicator is then derived as } \\
\text { a weighted aggregation of these sub-indicators, with weights } \\
\text { coming from principal component analysis. The new vintage of } \\
\text { this indicator uses constant weights. }\end{array}$ & $\begin{array}{l}\text { OECD countries, India } \\
\text { PMR for accession countries } \\
\text { is planned for 2009. PMR } \\
\text { for Chile was done in } 2001 \\
\text { Period: Three years } \\
\text { available 1998, 2003 and } \\
2007 \text { (will be available in } \\
2009 \text { ) }\end{array}$ & $\begin{array}{l}\text { Fact-based } \\
\text { Policy Indicators }\end{array}$ \\
\hline & ETCR (old regreff) & $\begin{array}{l}\text { These indicators have a more limited coverage of regulatory } \\
\text { issues than the PMR, but are computed for a long time series. } \\
\text { The indicators cover two groups of sectors: first, network } \\
\text { sectors (energy, transport and communication; and second, retail } \\
\text { trade and professional services. The methodology is similar than } \\
\text { the PMR's one but the indicators are more based on external } \\
\text { information and use equal weights. }\end{array}$ & $\begin{array}{l}\text { OECD countries } \\
\text { Period: Annual data, } 1975 \text { to } \\
2007 \\
\text { Irregular update }\end{array}$ & $\begin{array}{l}\text { Fact-based } \\
\text { Policy Indicators }\end{array}$ \\
\hline OECD & $\begin{array}{l}\text { Measure of entrepreneurship } \\
\text { (being developed by the } \\
\text { statistics Directorate) }\end{array}$ & & & $\begin{array}{l}\text { Fact and Perception- } \\
\text { based } \\
\text { Outcome indicator }\end{array}$ \\
\hline $\begin{array}{l}\text { Gallup World Poll } \\
\text { www.gallupworldpoll.com }\end{array}$ & Entrepreneurship Index & $\begin{array}{l}\text { The items comprising the Entrepreneurship Index accomplish } \\
\text { two objectives: they measure the intent of citizens to be in } \\
\text { business for themselves, and they assess the supportive nature } \\
\text { of the community for entrepreneurial business initiatives. } \\
\text { Questions in this index measure citizens' opinions about } \\
\text { planning their own business and other entrepreneurial issues. }\end{array}$ & $\begin{array}{l}140 \text { countries } \\
\text { The first round of data } \\
\text { collection was carried out in } \\
\text { late } 2005 \text { and } 2006 \text {. Citizens } \\
\text { are continuously surveyed } \\
\text { based on a telephone or } \\
\text { face-to-face interview }\end{array}$ & $\begin{array}{l}\text { Perception-based } \\
\text { Outcome indicator }\end{array}$ \\
\hline World economic forum: & Business competitivity index & $\begin{array}{l}\text { This indicator focuses on the micro-economic factors of } \\
\text { competitiveness. It is based on responses to the World }\end{array}$ & $\begin{array}{l}127 \text { countries in the } 2007- \\
2008 \text { report }\end{array}$ & Perception-based \\
\hline
\end{tabular}


ECO/WKP(2009)17

\begin{tabular}{|c|c|c|c|c|}
\hline http://www.gcr.weforum.org & & $\begin{array}{l}\text { Economic Forum's Executive Opinion Survey of senior } \\
\text { business leaders. The data are related to companies' operations } \\
\text { and strategy as to the national business environment. Countries } \\
\text { are divided in three groups according to their level of income } \\
\text { and weights differ according to the country group. Weights are } \\
\text { first calculated using principal factor analysis to compute two } \\
\text { sub-indicators. These two indicators are then aggregated in one } \\
\text { single measure using coefficients from a regression of GDP per } \\
\text { capita. }\end{array}$ & & Outcome indicators \\
\hline World Bank & Enterprise survey & $\begin{array}{l}\text { The Enterprise Surveys capture business perceptions on the } \\
\text { biggest obstacles to enterprise growth, the relative importance } \\
\text { of various constraints to increasing employment and } \\
\text { productivity, and the effects of a country's business } \\
\text { environment on its international competitiveness. } \\
\text { The core survey is organized into two parts. The first part seeks } \\
\text { managers' opinions on the main constraints in the business } \\
\text { environment. The second part focuses on productivity measures } \\
\text { and is often completed with help from the chief accountant or } \\
\text { manager. } \\
\text { human resource } \\
\text { The Enterprise Surveys sample from the universe of registered } \\
\text { businesses and follow a stratified random sampling } \\
\text { methodology. A small number of sectoral sub-samples are } \\
\text { included to provide measures of productivity that can be } \\
\text { compared to the same sectors in other countries. Because the } \\
\text { distribution of establishments in most countries is } \\
\text { overwhelmingly populated by small and medium enterprises, } \\
\text { surveys generally over-sample large establishments. Sample } \\
\text { sizes for recent enterprise surveys range from 250-1500 } \\
\text { businesses. }\end{array}$ & & $\begin{array}{l}\text { Perception-based } \\
\text { Policy Indicators }\end{array}$ \\
\hline World bank & $\begin{array}{l}\text { Djankov S., R. La Porta, F. } \\
\text { Lopez-de-Silanes, A. } \\
\text { Schliefer (2002) }\end{array}$ & $\begin{array}{l}\text { Data for five measures: the number of regulatory steps, the } \\
\text { number of work days required to register a new firm, the costs } \\
\text { of registering a firm as a per cent of the per capita GDP, the } \\
\text { time and costs of registering a new firm as a per cent of the per } \\
\text { capita GDP and the absolute dollar value of time and cost of } \\
\text { registering a new firm. }\end{array}$ & 85 countries & $\begin{array}{l}\text { Fact-based } \\
\text { Policy Indicators }\end{array}$ \\
\hline
\end{tabular}


ECO/WKP(2009)17

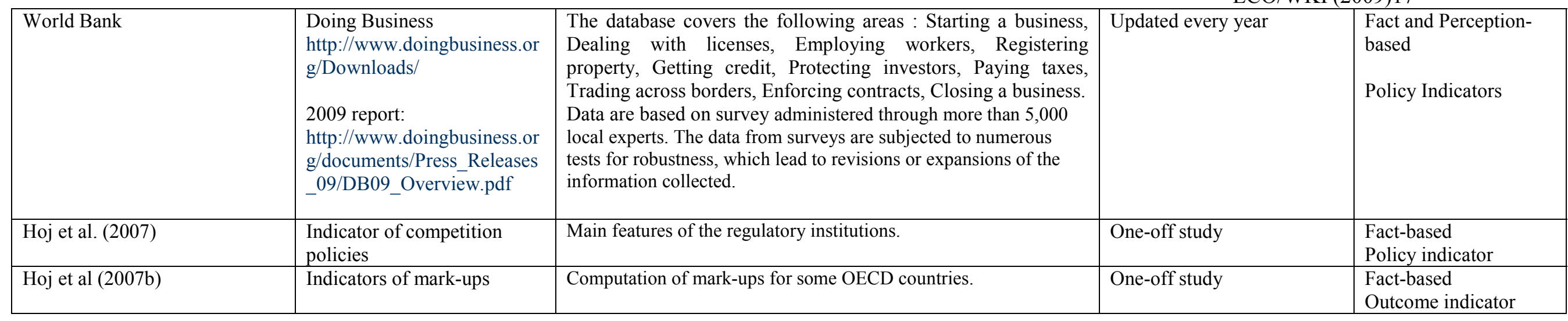


ECO/WKP(2009)17

\section{TRADE}

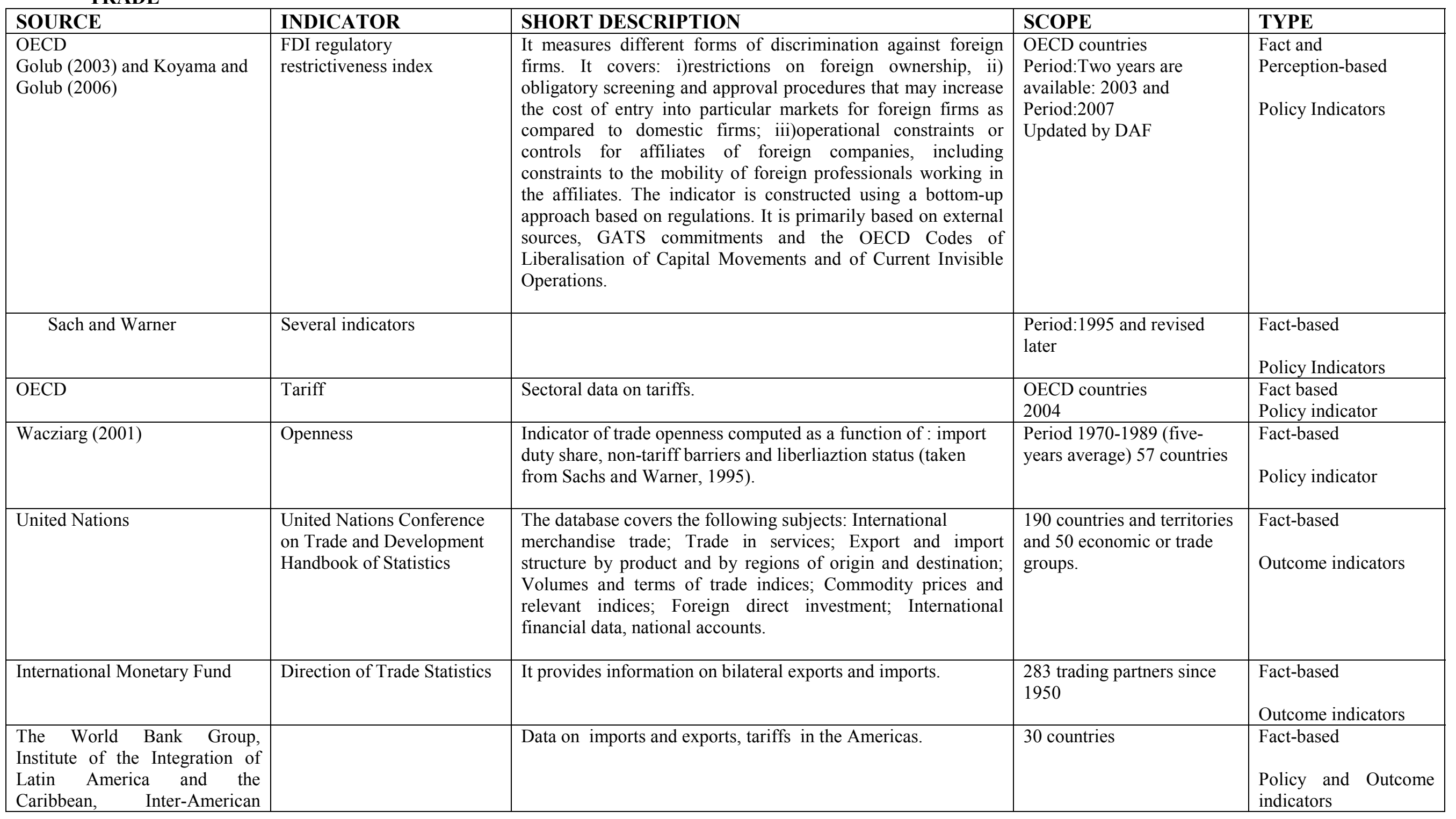


ECO/WKP(2009)17

\begin{tabular}{|c|c|c|c|c|}
\hline Development Bank & & & & \\
\hline $\begin{array}{l}\text { World Bank } \\
\text { http://econ.worldbank.org/WBSI } \\
\text { TE/EXTERNAL/EXTDEC/EXTR } \\
\text { ESEARCH/0,,contentMDK:210 } \\
\text { 51044 pagePK:64214825 piP } \\
\text { K:64214943 theSitePK:469382 } \\
\text {,00.html }\end{array}$ & $\begin{array}{l}\text { Data on Trade and Imports } \\
\text { barriers }\end{array}$ & Data on tariff, and non-tariff barriers. & $\begin{array}{l}174 \text { countries from 1980- } \\
2007 \text { (many missing) for } \\
\text { tariff rates } \\
89 \text { countries with different } \\
\text { (single) data points between } \\
\text { countries }\end{array}$ & $\begin{array}{l}\text { Fact-based } \\
\text { Policy Indicators }\end{array}$ \\
\hline *Heritage Foundation & Trade Freedom & $\begin{array}{l}\text { The trade freedom indicator score is based on two inputs: the } \\
\text { trade-weighted average tariff rate and non-tariff barriers } \\
\text { (NTBs). The weighted average tariff uses weights for each tariff } \\
\text { based on the share of imports for each good. This is calculated } \\
\text { by dividing the country's total tariff revenue by the total value } \\
\text { of imports. Weighted average tariffs are a purely quantitative } \\
\text { measure and account for the basic calculation of the score using } \\
\text { the following equation: } \\
\qquad \text { Tariff }_{\text {max }}-\text { Tariff }_{i} \\
\text { Tariff } \\
\text { max } \\
\text { where TF represents the trade freedom indicator. The minimum } \\
\text { tariff is zero, and the maximum tariff was set at } 50 \text { percent. An } \\
\text { NTB penalty is then subtracted from the base score. The penalty } \\
\text { of } 5,10,15 \text {,or } 20 \text { percentage points is assigned according to the } \\
\text { following scale: } 20 \% \text { if NTBs are used extensively across many } \\
\text { goods and services and/or act to impede a significant amount of } \\
\text { international trade; } 15 \% \text { if NTBs are widespread across many } \\
\text { goods and services and/or act to impede a majority of potential } \\
\text { international trade; } 10 \% \text { if NTBs are used to protect certain } \\
\text { goods and services and impede some international trade; } 5 \% \text { if } \\
\text { NTBs are uncommon, protecting few goods and services, and/or } \\
\text { have very limited impact on international trade: } 0 \% \text { if NTBs are } \\
\text { not used as a means to limit international trade.The extent of } \\
\text { NTBs in a country's trade policy regime is determined using } \\
\text { both qualitative and quantitative information. The categories of } \\
\text { NTBs considered are: quantity restrictions, price restrictions, }\end{array}$ & $\begin{array}{l}\text { Annual data available since } \\
1995 \text { for } 161 \text { countries. } \\
\text { The authors used the } \\
\text { following sources to } \\
\text { determine scores for trade } \\
\text { policy, in order of priority: } \\
\text { World Bank, World } \\
\text { Development Indicators } \\
2007 \text { and Data on Trade and } \\
\text { Import Barriers: Trends in } \\
\text { Average Tariff for } \\
\text { Developing and Industrial } \\
\text { Countries 1981-2005; } \\
\text { World Trade Organization, } \\
\text { Trade Policy Reviews, } \\
\text { 1995-2007; Office of the } \\
\text { U.S. Trade Representative, } \\
\text { 2007 National Trade } \\
\text { Estimate Report on Foreign } \\
\text { Trade Barriers; World Bank, } \\
\text { Doing Business 2008; U.S. } \\
\text { Department of Commerce, } \\
\text { Country Commercial Guide, } \\
\text { 2004-2007; Economist } \\
\text { Intelligence Unit, Country } \\
\text { Report, Country Profile, and } \\
\text { Country Commerce, 2004- } \\
\text { 2007; and official }\end{array}$ & $\begin{array}{l}\text { Fact-based } \\
\text { Policy Indicator }\end{array}$ \\
\hline
\end{tabular}




\begin{tabular}{|l|l|l|l|l|}
\hline & & $\begin{array}{l}\text { regulatory restrictions, custom restrictions and direct } \\
\text { government interventions. }\end{array}$ & $\begin{array}{l}\text { government publications of } \\
\text { each country. }\end{array}$ & \\
\hline $\begin{array}{l}\text { Fraser institute } \\
\text { Economic Freedom of the }\end{array}$ & $\begin{array}{l}\text { Financial Regulation \& } \\
\text { Forld }\end{array}$ & $\begin{array}{l}\text { It provides an index that measures the freedom to exchange with } \\
\text { foreigners. }\end{array}$ & $\begin{array}{l}\text { Data is available on 5-year } \\
\text { intervals since 1970 for up } \\
\text { to 123 countries }\end{array}$ & $\begin{array}{l}\text { Fact and perception- } \\
\text { based } \\
\text { Policy Indicator }\end{array}$ \\
\hline *PWT & Trade Openness & $\begin{array}{l}\text { A measure of trade intensity constructed as the GDP's share of } \\
\text { total exports and imports. }\end{array}$ & $\begin{array}{l}81 \text { countries } \\
\text { Outcome indicator }\end{array}$ \\
\hline
\end{tabular}

\section{INFRASTRUCTURE}

\section{SOURCE}

National Offices for Statistics

OECD STAN database

EU Klems database

National Offices for Statistics

\section{INDICATOR}

Capital stock

infrastructure

Public Private Partnership

indicator

\section{OECD}

OECD

\section{SHORT DESCRIPTION}

xamples are electricity generation capacity, road density, fixed ine provision, connection rates to water supply.

The indicator is based on qualitative information that is coded by assigning a numerical value to each of the possible responses to a given question or combination of questions that constitute a policy element identified as potentially affecting the success of PPPs. The coded information is then normalised on a scale of zero to six, reflecting practices that are increasingly likely not to lead to the best outcomes. The data is then aggregated into the low-level indicators by assigning equal weights to the various items of the indicator. Finally, the low-level indicators are aggregated into a higher-level (composite) indicator. In the absence of any theoretical guidance on their relative importance, equal weights were assigned to each lower-level indicator.

The data is based on the answer to a questionnaire on whether a sector is subject to incentive price regulation, in general in a form of a price cap.

\begin{tabular}{|l|l|}
\hline SCOPE & TYPE \\
\hline $\begin{array}{l}\text { 19 OECD countries } \\
\text { Late 2007-early 2008 }\end{array}$ & $\begin{array}{l}\text { Fact-based } \\
\text { Outcome indicator } \\
\text { Poct-Based }\end{array}$ \\
& $\begin{array}{l}\text { Folicy indicators } \\
\text { Policy indicator }\end{array}$ \\
\hline $\begin{array}{l}\text { Late 2007-Early 2008 } \\
\end{array}$ & \\
\hline
\end{tabular}


FINANCIAL MARKET

\begin{tabular}{|c|c|c|c|c|}
\hline SOURCE & INDICATOR & SHORT DESCRIPTION & SCOPE & TYPE \\
\hline $\begin{array}{l}\text { OECD bank profitability } \\
\text { statistics In oecd.stat }\end{array}$ & & $\begin{array}{l}\text { Bank profitability statistics are based on financial statements of } \\
\text { banks in each Member country and are presented in the standard } \\
\text { OECD framework. Although the objective is to include all } \\
\text { institutions which conduct ordinary banking business, namely } \\
\text { institutions which primarily take deposits from the public and } \\
\text { provide finance for a wide range of purposes, the institutional } \\
\text { coverage of banks in the statistics available in this database is } \\
\text { not the same in each country. } \\
\text { Example of variables include the Structure of the financial } \\
\text { sector, Bank income statement and balance sheets and Banks } \\
\text { assets and liabilities. }\end{array}$ & $\begin{array}{l}26 \text { countries } \\
\text { Period: } 1995 \text { to } 2005\end{array}$ & $\begin{array}{l}\text { Fact-based } \\
\text { Outcome indicators }\end{array}$ \\
\hline OECD & $\begin{array}{l}\text { Insurance Statistics } \\
\text { Yearbook }\end{array}$ & $\begin{array}{l}\text { The dataset gathered official data such as total Gross Premiums, } \\
\text { Market Share, Density, Penetration,Life Insurance Share, Direct } \\
\text { Total Gross Premiums/Number of Employees, Retention Ratio, } \\
\text { Ratio of Reinsurance Accepted, Market Shares. }\end{array}$ & $\begin{array}{l}\text { OECD countries } \\
1997-2006\end{array}$ & $\begin{array}{l}\text { Fact-Based } \\
\text { Outcome indicators }\end{array}$ \\
\hline
\end{tabular}




\begin{tabular}{|c|c|c|c|c|}
\hline & & $\begin{array}{l}\text { sophistication of the actors in these markets; rapid technological } \\
\text { change; and evolving regulatory frameworks. Financial } \\
\text { institutions react and adapt to these conditions by changing their } \\
\text { strategies; by specializing, by diversifying or concentrating their } \\
\text { activities, and by extending through mergers and acquisitions. } \\
\text { As a consequence, there is almost constant evolution in the } \\
\text { institutional structures in which financial markets operate. }\end{array}$ & & \\
\hline The World Bank & $\begin{array}{l}\text { World Development } \\
\text { Indicators }\end{array}$ & $\begin{array}{l}\text { WDI } 2008 \text { includes approx. } 800 \text { indicators in } 87 \text { tables, } \\
\text { organised in six sections: World View, People, Environment, } \\
\text { Economy, States and Markets, and Global Links. }\end{array}$ & $\begin{array}{l}54 \text { time series indicators for } \\
207 \text { countries and } 18 \text { groups, } \\
\text { data from } 1990 \text { to } 2006\end{array}$ & $\begin{array}{l}\text { Fact-based } \\
\text { Policy and } \\
\text { Outcome indicators }\end{array}$ \\
\hline De Serres and al. (2007) & $\begin{array}{l}\text { Set of indicators using the } \\
\text { World Bank }\end{array}$ & Regulation indicators in banking and security markets. & & $\begin{array}{l}\text { Perception-based } \\
\text { Policy Indicators }\end{array}$ \\
\hline The World Bank & $\begin{array}{l}\text { Global Development } \\
\text { Finance }\end{array}$ & $\begin{array}{l}\text { The database covers external debt stocks and flows, major } \\
\text { economic aggregates, and key debt ratios as well as average } \\
\text { terms of new commitments, currency composition of long-term } \\
\text { debt, debt restructuring, and scheduled debt service projections. }\end{array}$ & 136 countries & $\begin{array}{l}\text { Fact-based } \\
\text { Outcome indicators }\end{array}$ \\
\hline International Monetary Fund & $\begin{array}{l}\text { International Financial } \\
\text { Statistics }\end{array}$ & $\begin{array}{l}\text { Data related on international payments, inflation, exchange } \\
\text { rates, international liquidity, international banking, money and } \\
\text { banking, interest rates, prices, production, international } \\
\text { transactions, government accounts, and national accounts. }\end{array}$ & & $\begin{array}{l}\text { Fact-based } \\
\text { Performance Indicators }\end{array}$ \\
\hline $\begin{array}{l}\text { The International } \\
\text { Finance Corporation \& } \\
\text { Standard and Poors }\end{array}$ & $\begin{array}{l}\text { Emerging Markets Data } \\
\text { Base }\end{array}$ & $\begin{array}{l}\text { Three families of indices: the IFCI (Investable) index, } \\
\text { which measures returns on stocks that are available to foreign } \\
\text { investors; the IFCG (Global) indexes, which track the } \\
\text { performance of the most active stocks in their respective stock } \\
\text { markets even if the stocks are unavailable to foreign investors } \\
\text { (the broadest indicator of market movements); and the } \\
\text { IFCF (Frontier Markets) index of } 20 \text { smaller markets. }\end{array}$ & $\begin{array}{l}\text { The EMDB provides daily } \\
\text { coverage of } 34 \text { stock } \\
\text { markets and weekly and } \\
\text { monthly reports of another } \\
20 \text { less liquid "frontier } \\
\text { markets." }\end{array}$ & $\begin{array}{l}\text { Fact-based } \\
\text { Outcome indicators }\end{array}$ \\
\hline J P Morgan & $\begin{array}{l}\text { The Emerging Market Bond } \\
\text { Index }\end{array}$ & $\begin{array}{l}\text { The Emerging Markets Bond Index Plus }(\mathrm{EMBI}+) \text { tracks total } \\
\text { returns for traded external debt instruments in the emerging } \\
\text { markets. }\end{array}$ & $\begin{array}{l}\text { Three major Latin American } \\
\text { countries (Argentina, Brazil, } \\
\text { and Mexico) and other } \\
\text { emerging market countries } \\
\text { (Bulgaria, Morocco, }\end{array}$ & $\begin{array}{l}\text { Fact-based } \\
\text { Performance Indicators }\end{array}$ \\
\hline
\end{tabular}


ECO/WKP(2009)17

\begin{tabular}{|c|c|c|c|c|}
\hline & & & $\begin{array}{l}\text { Nigeria, the Philippines, } \\
\text { Poland, Russia, and South } \\
\text { Africa). }\end{array}$ & \\
\hline $\begin{array}{l}\text { *A New Database on Financial } \\
\text { Development and Structure } \\
\text { (2007); } \\
\text { Beck et al . ( World Bank) }\end{array}$ & $\begin{array}{l}\text { Set of indicators using the } \\
\text { world Bank }\end{array}$ & $\begin{array}{l}\text { Set of indicator measuring the size, concentration, efficiency of } \\
\text { financial markets. }\end{array}$ & $\begin{array}{l}151 \text { countries. For some } \\
\text { countries data available } \\
\text { since } 1960 .\end{array}$ & $\begin{array}{l}\text { Fact-based } \\
\text { Policy and Performance } \\
\text { Indicators }\end{array}$ \\
\hline $\begin{array}{l}\text { "The Regulation and } \\
\text { Supervision of Banks around } \\
\text { the World: A New Database } \\
\text { (2008)" G. Caprio, J. Barth and } \\
\text { R.Levine } \\
\text { http://econ.worldbank.org/WBS } \\
\text { ITE/EXTERNAL/EXTDEC/EX } \\
\text { TRESEARCH/0,,contentMDK: } \\
\text { 20345037 pagePK:64214825 p } \\
\text { iPK:64214943 theSitePK:4693 } \\
\text { 82,00.html\#Survey_III }\end{array}$ & & $\begin{array}{l}\text { The data cover such aspects of banking as entry requirements, } \\
\text { ownership restrictions, capital requirements, activity } \\
\text { restrictions, external auditing requirements, characteristics of } \\
\text { deposit insurance schemes, loan classification and provisioning } \\
\text { requirements, accounting and disclosure requirements, troubled } \\
\text { bank resolution actions, and (uniquely) the quality of } \\
\text { supervisory personnel and their actions. }\end{array}$ & $\begin{array}{l}143 \text { countries. Three point } \\
\text { in time: } 1998,2003,2007 . \\
\text { Previous versions: } 2001 \text { and } \\
2003 \text {. }\end{array}$ & $\begin{array}{l}\text { Perception-based } \\
\text { Policy Indicator }\end{array}$ \\
\hline BANKSCOPE & & $\begin{array}{l}\text { It provides information on over } 28,600 \text { ( } 13,600 \text { US) banks listed } \\
\text { around the world including: } 16 \text { years of detailed accounts } \\
\text { (country specific "as reported" and standardised), ratios, ratings } \\
\text { and rating reports, ownership, country risk and country finance } \\
\text { reports. }\end{array}$ & & $\begin{array}{l}\text { Fact-based } \\
\text { Policy and Outcome } \\
\text { indicators }\end{array}$ \\
\hline International Monetary Fund & $\begin{array}{l}\text { Balance of Payments } \\
\text { Statistics }\end{array}$ & $\begin{array}{l}\text { The Statistics Department of the IMF disseminates a wide range } \\
\text { of information in the area of balance of payments and } \\
\text { international investment position (IIP) statistics. This material } \\
\text { includes: Data on international reserves and foreign currency } \\
\text { liquidity, external debt, and balance of payments flows. }\end{array}$ & & $\begin{array}{l}\text { Fact-based } \\
\text { Outcome indicators }\end{array}$ \\
\hline International Monetary Fund & $\begin{array}{l}\text { Exchange Arrangements and } \\
\text { Exchange Restrictions } \\
\text { Report }\end{array}$ & $\begin{array}{l}\text { The report provides a detailed description of arrangements and } \\
\text { restrictions on exchange rates, current account transactions, and } \\
\text { capital transactions (qualitative data). }\end{array}$ & & $\begin{array}{l}\text { Fact and Perception- } \\
\text { based } \\
\text { Policy Indicators }\end{array}$ \\
\hline OECD & $\begin{array}{l}\text { International Direct } \\
\text { Investment }\end{array}$ & $\begin{array}{l}\text { This database gathers detailed historical statistics on } \\
\text { international direct investment to and from OECD countries. }\end{array}$ & & $\begin{array}{l}\text { Fact-based } \\
\text { Outcome indicators }\end{array}$ \\
\hline
\end{tabular}


ECO/WKP(2009)17

\begin{tabular}{|c|c|c|c|c|}
\hline & & $\begin{array}{l}\text { Data are broken down by country, geographical zone, and } \\
\text { industrial sector for direct investment flows and } \\
\text { stocks. }\end{array}$ & & \\
\hline OECD & Private Pensions Database & $\begin{array}{l}\text { This database contains information on all aspects of the } \\
\text { regulatory framework of private pension systems in OECD and } \\
\text { non-OECD countries. }\end{array}$ & & $\begin{array}{l}\text { Fact-based } \\
\text { Policy Indicators }\end{array}$ \\
\hline $\begin{array}{l}\text { The Financial Development } \\
\text { Report 2008, World Economic } \\
\text { Forum }\end{array}$ & Financial Development & $\begin{array}{l}\text { Index of financial development standardized on a } 1 \text { to } 7 \text { scale. It } \\
\text { considers different aspect of financial development: institutional } \\
\text { environment, business environment, financial stability, banks, } \\
\text { non-banks, financial -market, size, deepness and access. }\end{array}$ & 52 countries & $\begin{array}{l}\text { Fact and perception } \\
\text { based } \\
\text { Policy and Outcome } \\
\text { indicators }\end{array}$ \\
\hline BIS, Statistics & $\begin{array}{l}\text { Banking, securities, } \\
\text { derivatives, exchange rates, } \\
\text { debt, payments. }\end{array}$ & $\begin{array}{l}\text { The cross-border lending and borrowing of internationally } \\
\text { active banks in key financial centers, including offshore centers; } \\
\text { issuing activity in international and domestic securities markets; } \\
\text { operations in over-the-counter and exchange-traded derivatives } \\
\text { markets; effective exchange rate (EER) indices for } 52 \\
\text { economies; operations in the global foreign exchange markets; } \\
\text { external debt positions of individual countries based on BIS } \\
\text { banking and securities statistics as well as on data from other } \\
\text { international organizations; payment and settlement systems in } \\
\text { major financial centers. }\end{array}$ & & $\begin{array}{l}\text { Fact- based } \\
\text { Outcome indicators }\end{array}$ \\
\hline ECB, financial statistics & $\begin{array}{l}\text { Monetary and financial } \\
\text { statistics }\end{array}$ & $\begin{array}{l}\text { Statistics regarding monetary financial institutions (MFIs), } \\
\text { investment funds, financial stability and financial markets, and } \\
\text { payments within the euro area. This includes the monetary } \\
\text { aggregates (See the ECB's definition of monetary aggregates), } \\
\text { their counterparts and other monetary stocks and flows } \\
\text { statistics, including minimum reserve and liquidity statistics and } \\
\text { all seasonally adjusted statistics; statistics on securities issues } \\
\text { (including quoted shares), investment funds and other financial } \\
\text { intermediaries; statistics on yields and interest rates; banking } \\
\text { statistics; financial market statistics; and financial integration } \\
\text { indicators. }\end{array}$ & European countries & $\begin{array}{l}\text { Fact based } \\
\text { Outcome indicators }\end{array}$ \\
\hline $\begin{array}{l}\text { *“Financial Reform: What } \\
\text { Shakes it? What Shapes it?" } \\
\text { Abiad and Mody , (2005) } \\
\text { This database has been extended }\end{array}$ & Financial Liberalisation & $\begin{array}{l}\text { Financial liberalisation based on the following criteria: Credit } \\
\text { control, Interest rate control, Entry barriers, Regulations, } \\
\text { Privatization, International transactions. }\end{array}$ & $\begin{array}{l}36 \text { economies from } 1973 \\
\text { to } 1996\end{array}$ & $\begin{array}{l}\text { Fact and } \\
\text { Perception based } \\
\text { Policy Indicator }\end{array}$ \\
\hline
\end{tabular}


ECO/WKP(2009)17

\begin{tabular}{|c|c|c|c|c|}
\hline $\begin{array}{l}\text { and updated in Abiad et al. } \\
\text { (2008) }\end{array}$ & & & & \\
\hline *Heritage Foundation & Financial Freedom & $\begin{array}{l}\text { It measures the relative openness of a country's banking and } \\
\text { financial system. }\end{array}$ & $\begin{array}{l}\text { Annual data available since } \\
1995 \text { for } 161 \text { countries }\end{array}$ & $\begin{array}{l}\text { Fact and Perception- } \\
\text { based } \\
\text { Policy Indicator }\end{array}$ \\
\hline $\begin{array}{l}\text { Fraser institute } \\
\text { Economic Freedom of the } \\
\text { World }\end{array}$ & $\begin{array}{l}\text { Financial Regulation \& } \\
\text { Freedom }\end{array}$ & $\begin{array}{l}\text { It provides and index of regulation of credit, which includes } \\
\text { information on ownership of banks, competition from foreign } \\
\text { banks, availability of credit to the private sector, avoidance of } \\
\text { interest rate controls and regulations that lead to negative real } \\
\text { interest rates. It provides an index that measures the freedom to } \\
\text { exchange with foreigners }\end{array}$ & $\begin{array}{l}\text { Data is available on } 5 \text {-year } \\
\text { intervals since } 1970 \text { for up } \\
\text { to } 123 \text { countries }\end{array}$ & $\begin{array}{l}\text { Fact and } \\
\text { Perception-based } \\
\text { Policy Indicator }\end{array}$ \\
\hline${ }^{*}$ Lane and Milessi-Ferretti (2007) & Financial Integration & $\begin{array}{l}\text { Indicators of financial liberalization and integration: the GDP's } \\
\text { ratio of overall stock of external liabilities and assets, the GDP's } \\
\text { share of portfolio equity and FDI, and the share of equity } \\
\text { liabilities in total liabilities. }\end{array}$ & $\begin{array}{l}\text { Annual data from 1970- } \\
2004\end{array}$ & $\begin{array}{l}\text { Fact based } \\
\text { Outcome indicators }\end{array}$ \\
\hline Laeven Valencia (2008) & Banking crises & $\begin{array}{l}\text { The database covers all systemically important banking crises } \\
\text { for the period } 1970 \text { to } 2007 \text {, and has detailed information on } \\
\text { crisis management strategies for } 42 \text { systemic banking crises } \\
\text { from } 37 \text { countries. The authors also provide information } \\
\text { regarding currency crises, sovereign debt crises and twin crises. }\end{array}$ & $1970-2007$ & $\begin{array}{l}\text { Fact based } \\
\text { Outcome indicator }\end{array}$ \\
\hline
\end{tabular}




\section{ECO/WKP(2009)17}

\section{COMPOSITE OR REFORM INDICATOR}

\begin{tabular}{|c|c|c|c|c|}
\hline SOURCE & INDICATOR & SHORT DESCRIPTION & SCOPE & TYPE \\
\hline Lora and Panizza (2002) & Indicator of reform progress & $\begin{array}{l}\text { Measure of the progress of reform on a scale from } 0 \text { to } 1 \text {. It's an } \\
\text { average of } 5 \text { areas of reform: trade liberalization, financial } \\
\text { reform, tax reform, privatization and labour code legislation. } \\
\text { Disaggregated indicator by area is also available. } \\
\text { Data have been first developed by Lora (2001) and updated } \\
\text { using reviews of the IMF and The Economist Intelligence Unit. }\end{array}$ & $\begin{array}{l}10 \text { Latin America economies } \\
\text { Annual data } \\
\text { Period: } 1985 \text { to } 1999 \\
\text { One-off study }\end{array}$ & $\begin{array}{l}\text { Performance-based } \\
\text { Policy Indicator }\end{array}$ \\
\hline Eicher and Röhn (2007) & Institutions Climate index & $\begin{array}{l}\text { Composite index of } 7 \text { categories: constitutional system } \\
\text { [democratic system, political stability, civil liberties, checks and } \\
\text { constraints], social conflict potential [conflict, military in } \\
\text { politics], administrative and judicial quality [basic institutional } \\
\text { quality], economic institutions [optimal taxation, fiscal burden, } \\
\text { trade openness, capital markets, labour markets, structure of } \\
\text { government expenditure], Educational system [human capital } \\
\text { efficiency], Social system [social expenditure, health system], } \\
\text { Innovation potential [ patents and citations]. } \\
\text { Aggregation is done using factor analysis and regression } \\
\text { analysis on GDP per capita growth rates. }\end{array}$ & $\begin{array}{l}\text { 24 OECD countries } \\
\text { Period: Annual data } 1994 \text { to } \\
2006 \\
\text { One-off study }\end{array}$ & $\begin{array}{l}\text { Fact and Perception- } \\
\text { based } \\
\text { Policy Indicator }\end{array}$ \\
\hline Hoj et al. (2006) & Indicator of reform effort & $\begin{array}{l}\text { Simple average of labour (or product) market institutions for } \\
\text { OECD countries. }\end{array}$ & OECD countries & $\begin{array}{l}\text { Fact-based } \\
\text { Policy indicator }\end{array}$ \\
\hline $\begin{array}{l}\text { European Commission (DG } \\
\text { ECFIN) }\end{array}$ & MICREF & $\begin{array}{l}\text { The database covers microeconomic reform measures in all EU } \\
\text { Member States. Only reform measures that are likely to have a } \\
\text { significant economic impact and to raise potential growth are } \\
\text { included in the database. The database also offers information } \\
\text { on the design and scope of reforms undertaken. } \\
\text { Seven broad policy fields are covered: market integration; } \\
\text { competition policy; sector-specific regulation; start-up } \\
\text { conditions; business environment; R\&D and innovation; and } \\
\text { education; each policy field is subdivided into areas of policy } \\
\text { intervention. }\end{array}$ & $\begin{array}{l}27 \text { EU countries } \\
\text { Data from } 2004 \text { to } 2006 \\
\text { Data for } 2007 \text { and } 2008 \text { will } \\
\text { be avalaible soon }\end{array}$ & $\begin{array}{l}\text { Fact and perception } \\
\text { based } \\
\text { Policy indicator }\end{array}$ \\
\hline World economic forum: & Global competitivity indices & $\begin{array}{l}\text { A global indicator with } 3 \text { components: basic requirement } \\
\text { (institution, infrastructure, macro stability, health and primary }\end{array}$ & $\begin{array}{l}131 \text { countries. } \\
\text { (over } 11,000 \text { business leaders) }\end{array}$ & Perception-based \\
\hline
\end{tabular}


ECO/WKP(2009)17

\begin{tabular}{|c|c|c|c|}
\hline http://www.gcr.weforum.org & $\begin{array}{l}\text { education), efficiency enhancers (higher efficiency and training, } \\
\text { good market efficiency, labour market efficiency, financial } \\
\text { market sophistication, technological readiness, market size). } \\
\text { All the breakdown information is available on the website. } \\
\text { Besides hard data from leading international sources, these } \\
\text { indicators include the results of the Executive Opinion Survey } \\
\text { carried out by the World Economic Forum annually. The } \\
\text { Survey captures the perceptions of several thousand business } \\
\text { leaders across the countries covered on topics related to national } \\
\text { competitiveness. } \\
\text { The rankings are calculated from both publicly available data } \\
\text { and the Executive Opinion Survey, a comprehensive annual } \\
\text { survey conducted by the World Economic Forum together with } \\
\text { its network of Partner Institutes (leading research institutes and } \\
\text { business organizations) in the countries covered by the Report. }\end{array}$ & $\begin{array}{l}\text { First release in } 2004 \\
\text { Annual update }\end{array}$ & Policy Indicators \\
\hline
\end{tabular}




\section{WORKING PAPERS}

The full series of Economics Department Working Papers can be consulted at www.oecd.org/eco/Working_Papers/

675. Stabilization Effects of Social Spending: Empirical Evidence from a Panel of OECD Countries (February 2009) Davide Furceri

674. Fiscal Convergence, Business Cycle Volatility and Growth (February 2009) Davide Furceri

673. Boosting Productivity in Korea's service sector (February 2009) Randall S. Jones

672. Sustaining growth in Korea by reforming the labour market and improving the education system (February 2009) Randall S. Jones and Masahiko Tsutsumi

671. Reforming the tax system to promote economic growth and cope with rapid population ageing (February 2009) Randall S. Jones

670. Financial market stability: Enhancing regulation and supervision (February 2009) Jeremy Lawson, Sebastian Barnes and Marte Sollie

669. Overcoming the financial crisis (February 2009) Andrea De Michelis

668. Financial crises: past lessons and policy implications (February 2009) Davide Furceri and Annabelle Mourougane

667. Reforms to open sheltered sectors to competition in Switzerland (February 2009) Andrés Fuentes

666. Raising education outcomes in Spain (February 2009) Andrés Fuentes

665. Health care reform in the United States (February 2009) David Carey, Bradley Herring and Patrick Lenain

664. The role of $R \& D$ and technology diffusion in climate change mitigation: new perspectives using the WITCH model (February 2009) Valentina Bosetti, Carlo Carraro, Romain Duval, Alessandra Sgobbi and Massimo Tavoni

663. Long-run GDP growth framework and scenarios for the world economy (January 2009) Romain Duval and Christine de la Maisonneuve

662. Realising South Africa's employment potential (January 2009) Geoff Barnard

661. Making the most of Norwegian schools (January 2009) Romina Boarini 
660 Can the financial sector continue to be the main growth engine in Luxembourg?

(January 2009) Arnaud Bourgain, Patrice Pieretti and Jens Høj

659. Fiscal policy responsiveness, persistence, and discretion (December 2008) António Afonso, Luca Agnello, Davide Furceri

658. The economics of climate change mitigation: policies and options for the future (December 2008) Jean-Marc Burniaux, Jean Chateau, Romain Duval and Stéphanie Jamet

657. Maximising Mexico's gains from integration in the world economy (December 2008) David Haugh, Roselyne Jamin and Bruno Rocha

656. How do taxes affect investment and productivity? An industry-level analysis of OECD countries (December 2008) Laura Vartia

655. Strategies for countries with favourable fiscal positions (November 2008) Robert Price, Isabelle Joumard, Christophe André and Makoto Minegishi

654. Monetary transmission mechanism in Central and Eastern Europe: Surveying the Surveable (November 2008) Balázs Égert and Ronald MacDonald

653. An Overview of the OECD ENV-Linkages Model Jean-Marc Burniaux and Jean Château

652. Reforming the labour market in Japan to cope with increasing dualism and population ageing (November 2008) Randall S. Jones

651. Enhancing the productivity of the service sector in Japan (November 2008) Randall S. Jones and Taesik Yoon

650. Reforming the tax system in Japan to promote fiscal sustainability and economic growth (November 2008) Randall S. Jones and Masahiko Tsutsumi

649. What Drives the NAIRU? Evidence from a Panel of OECD Countries (November 2008) Christian Gianella, Isabell Koske, Elena Rusticelli and Olivier Chatal

648. Short-term distributional effects of structural reforms: selected simulations in a DGSE framework (October 2008) Annabelle Mourougane and Lukas Vogel

647. Speed of adjustment to selected labour market and tax reforms (October 2008) Annabelle Mourougane, Lukas Vogel

646. The challenge of monetary policy in Turkey (October 2008) Olcay Çulha, Ali Çulha and Rauf Gönenç 